\title{
THE BARZAVAND AND NEYSIAN COPPER DEPOSITS, NW NAEIN, CENTRAL IRAN ZONE: CONSTRAINTS ON STYLES OF MINERALIZATION AND GEOCHEMICAL SIGNATURES OF HYDROTHERMAL ALTERATIONS
}

\author{
Shahram MOBASER ${ }^{1)}$, Taher FARHADINEJAD ${ }^{1,2)}$ *, Abbas ASGARI ${ }^{3)}$, \\ Mohammad Ali Ali ABADI ${ }^{3)}$ and Shirin FATAHI ${ }^{1,4)}$ \\ 1) Earth Sciences Department, Technical Engineering faculty, Mahallat Branch, Islamic Azad University, Mahallat, Iran \\ 2) Soil Conservation and Watershed Management Research Department, Lorestan Agricultural and Natural Resources Research and \\ Education Center, AREEO, Khoramabad, Iran \\ ${ }^{3)}$ Faculty member of Earth Sciences Department, Technical Engineering faculty, Mahallat Branch, Islamic Azad University, Mahallat, Iran \\ 4) Department of Geology, Faculty of Natural Sciences, University of Tabriz, Tabriz, Iran
}

*Corresponding author's e-mail: farhadinejad@gmail.com

\begin{tabular}{|c|c|}
\hline ARTICLE INFO & ABSTRACT \\
\hline Article history: & \multirow{14}{*}{$\begin{array}{l}\text { Field observations in the northwest of Naein (Central Iran zone) indicate various types of alteration } \\
\text { products have extended into pyroclastic and volcanic units with Oligo- miocene age. It seems the } \\
\text { Zefreh (with NW-SE trend) and Kachumesqal (with E-W trend) faults are effective factors in the } \\
\text { formation of Neysian and Barzavand copper deposits respectively. Alteration in Barzavand copper } \\
\text { deposit (with stratabound form) includes pyritization, propylitization, zeolitization, } \\
\text { saussuritization, uralitization and silicification, while in Neysian (with oval form) include phyllic, } \\
\text { advanced argillic, argillic and propylitic. Geochemical studies in Barzavand show the positive } \\
\text { correlation between }(\mathrm{La} / \mathrm{Lu})_{\mathrm{N}},(\mathrm{La} / \mathrm{Yb})_{\mathrm{N}} \text { and }(\mathrm{La} / \mathrm{Sm})_{\mathrm{N}} \text { and } \mathrm{CaO}(\mathrm{r}=0.70 \text { to } 0.96) \text { related to } \\
\text { propylitization of host rock basalt and increase in } \mathrm{pH} \text { of fluids responsible for mineralization that } \\
\text { play important role in differentiation of lanthanides in study area. The Barzavand copper deposit } \\
\text { has submarine volcanism, diagenesis, burial metamorphism and weathering stages during its } \\
\text { evolution. Remarkable geochemical features in Neysian include high }(\mathrm{La} / \mathrm{Lu})_{\mathrm{N}} \text {, Ba and Sr values } \\
\text { than La, Ce and Y. It seems that extensive alteration occurred along with hypogene and supergene } \\
\text { processes in Neysian. According to alteration properties, mineralogy and the whole-rock } \\
\text { geochemistry, the Barzavand and Neysian copper deposits are most similar to Manto- type and } \\
\text { porphyry copper deposits respectively. }\end{array}$} \\
\hline er 2021 & \\
\hline$A$ & \\
\hline Available online $21 \mathrm{Dec}$ & \\
\hline & \\
\hline кеу & \\
\hline Alte & \\
\hline Argi & \\
\hline Phyllic & \\
\hline Propylitic & \\
\hline tization & \\
\hline Uralitization & \\
\hline Neysian & \\
\hline Barza & \\
\hline
\end{tabular}

\section{INTRODUCTION}

Alteration happens when hydrothermal fluids flow through specific channels in the Earth crust or over specific parts of the crust surface and redeposit the finite volume of minerals from dissolved materials (Lobato et al., 1998). The hydrothermal alteration assemblages around the breccia zones, faults, and fracture systems, are due to interaction between metasomatic fluids and wall rock to gain chemical, isotopic, and thermal equilibrium. Hydrothermal alteration is result of the chemical replacement of major rock minerals by new minerals through interaction between wall rock and hydrothermal fluids (without considering the composition and source of hydrothermal fluid) (Zhou and Wang, 1999). This fluid can dissolve and move different materials that is due to the partial or complete decomposition of wall rock and is mostly accompanied by an increase and decrease in chemical compositions.

In a general division, the wall rock alteration can be divided into 2 main types (Shahabpour, 2001):

1. Endogenous alteration: it is due to the effect of ascending hydrothermal fluid and wall rock.
2. Exogenous alteration: the exogenous alteration occurs due to interaction between descending hydrothermal fluid and previous rock minerals.

The study area with geography coordinate $52^{\circ} 17^{\prime}$ to $52^{\circ} 43^{\prime}$ longitude and $32^{\circ} 54^{\prime}$ to $33^{\circ} 23^{\prime}$ latitude is located $\sim 70 \mathrm{Km}$ from Northeast of Zefreh Village (Isfahan province, Iran). In the Northeast of Zefreh, there are a different type of alteration which closely related to regional tectonics. Generally, in study area the faults have 3 trends: NW- SE (such as Zefreh, Ardestan, Kashan, Marbin faults and ...), E- W (Kachumesqal and Zafarqand faults) with extensive alteration process and NE- SW (without alteration process) trends. Different copper deposits occur in association with the Zefreh fault such as the Kahang porphyry Cu- Mo deposit (Komeili et al., 2017). The Zefreh fault plays an important role in the exposure of volcanic and volcano-sedimentary rocks (due to subduction of Neo- Tethys below Eurasian plate) and subsequently providing enough open spaces for intrusion of granodiorite bodies with Oligo- miocene age (that affected the Eocene units by hydrothermal fluids) at the same time. 


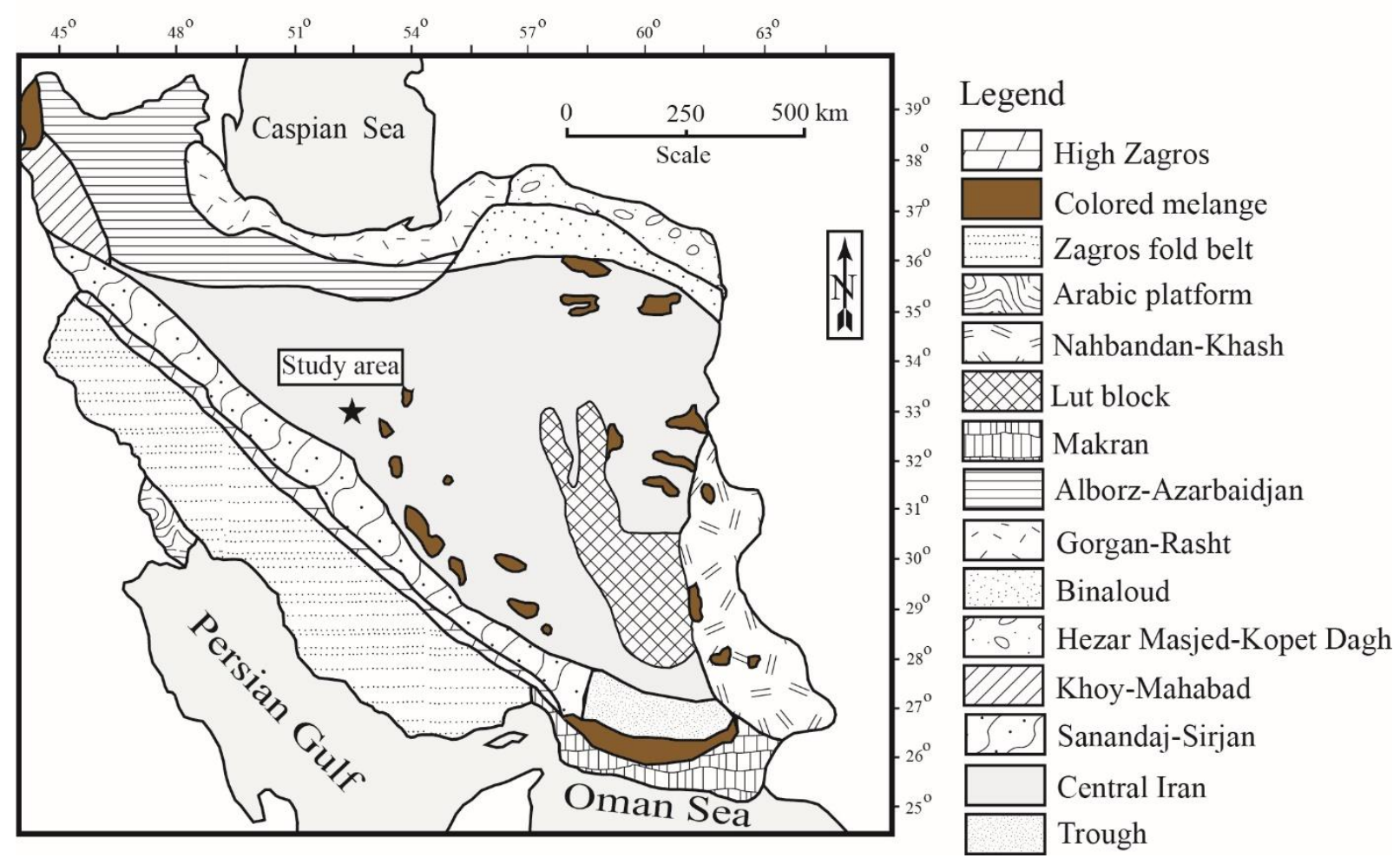

Fig. 1 Classification of tectonic units of Iran (Nabavi, 1976) with some modification and the location of the study area.

For the first time Beygi et al. (2016) with a detailed tectonic study, identified dykes, veins and tension fractures with the E- W trend (parallel to Kachumesqal and Zafarqand faults) have been hosted by copper deposits. Mohammadi et al. (2018) studied remote sensing to establish relationship between tectonic features, dikes and veins with alteration zones. Considering previous studies, with the help of field observations, tectonic and alteration maps and their incorporation with uni and multi elements geochemical halo, other faults with the E- W trend were studied. These studies led to the discovery of buried Barzavand and Eshkaft copper deposits.

Over past decades, alteration systems in different parts of the world have been studied in detail for their origin, genesis and behavior of major, trace, and especially rare earth elements by many researchers (Babazadeh et al., 2021; Abedini, 2017; Fatahi et al., 2016; Huang et al., 2019; Craverio et al., 2019; Xiao et al., 2018; Zhou et al., 2020; Niu et al., 2020; Tassongwa et al., 2017; Behyari et al., 2020). It is clear that mineralogical and geochemical properties of alteration zones have scientific importance in exploration of metallic potential resources. However, there were no comprehensive investigations on the Barzavand and Neysian alteration systems. In this contribution, we suggest relatively comprehensive data on mineralogical characteristics, factors controlling the mobility, distribution, enrichment and depletion of major, trace and rare earth elements during the evolution of these deposits.

\section{TECTONIC SETTING AND GEOLOGY OF DEPOSITS}

According to Nabavi (1976), the study area is a part of the central Iran structural zone and near the Urumieh- Dokhtar magmatic belt (Fig. 1). According to $1 / 100000$ geology maps of Ardestan and Kuhpayeh and $1 / 250000$ geology map of Naein, the major lithologic units in study area from the oldest to the youngest include: shale, conglomerate and sandstone (Lower Eocene), andesite basalt, rhyolite and ignimbrite with NE- SW trend (Upper Eocene), rhyodacite, dacite, diorite, granodiorite and quartzdiorite (Oligo- miocene), basalt hosted $\mathrm{Cu}$-minerals in Barzavand (Oligo- miocene), Limestone, volcano- sedimentary units and andesite (Oligo- miocene) and quaternary alluvial sediments (Fig. 2) (Baluchi Anaraki and Mackizadeh, 2013; Radfar and Aminichehraq, 2008; Nabavi and Houshmandzadeh, 1979; Radfar et al., 2003).

The intrusive rocks with Oligo -miocene age affected the volcanic and pyroclastic units with Eocene age by hydrothermal fluids and caused the formation of porphyry copper deposits such as Kahang and Zafarqand. For complete description of form, expansion, and separation of the alteration zone in the study area, the Aster satellite images have been used. After the decrease of dust subtraction, atmospheric correction (by using of $\log$ residual method), mask of vegetation (NDVI calculation method by use of $3 / 2$ band ratio), and false color composition (RGB: 468) were applied. Finally, total argillic- silicic and 


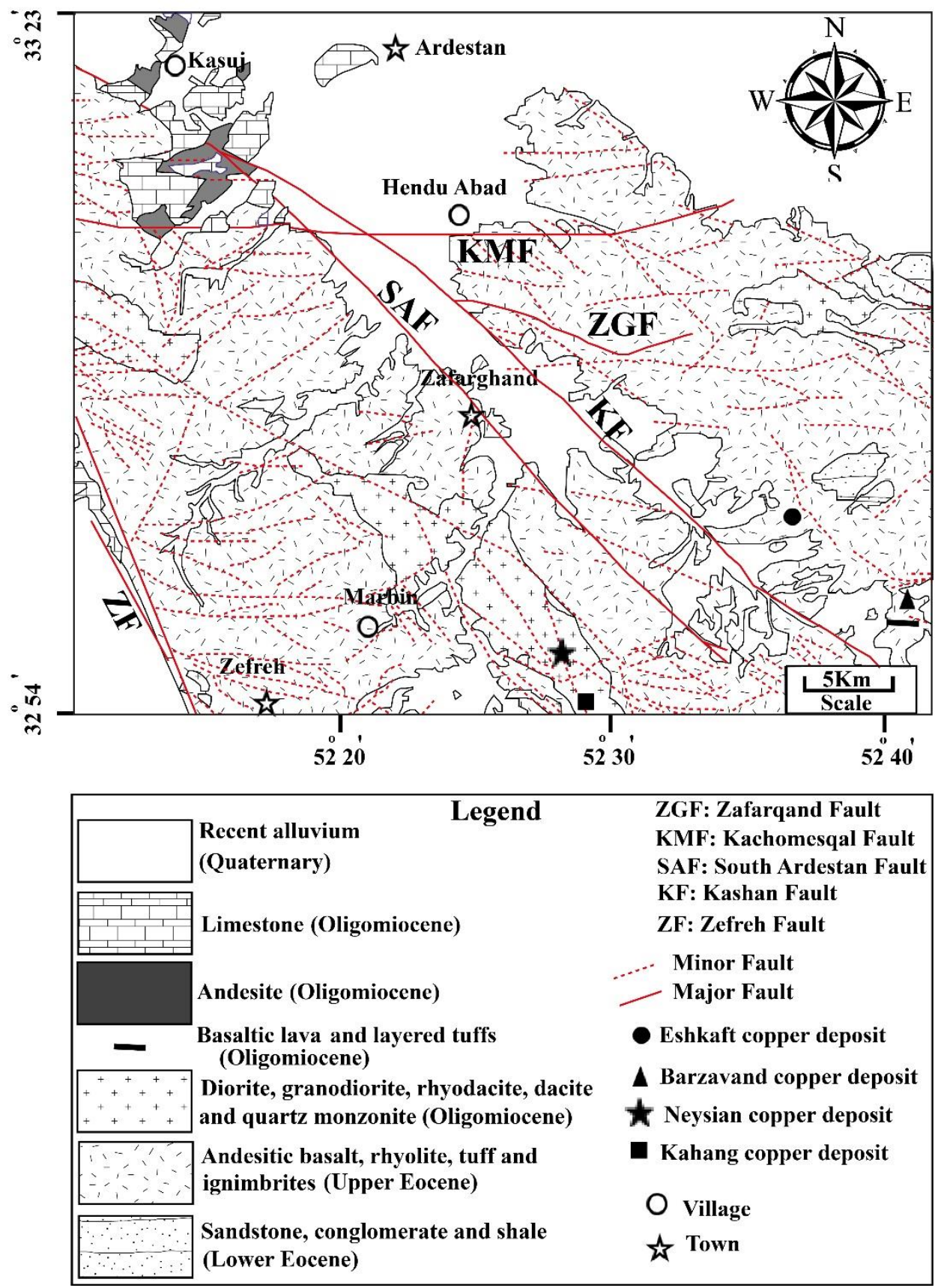

Fig. 2 Geologic map of the study area illustrating the location of different types of copper deposit in Northwest of Naein (Radfar and Aminichehraq, 2008; Nabavi and Houshmandzadeh, 1979 and Radfar et al., 2003).

propylitic alteration zones were seen in pink and green colors respectively (Fig. 3a).

For extraction of phyllic alteration zone, the 4/6 Band ratio has been used and illustrated by yellow color (Fig. 3b). The Barzavand has stratified alteration form in E-W trend (Fig. 3a). With study of alteration area in the field, it is a silicified tuff unit because of high hardness than other adjacent rock units show an outcrop. By drilling an exploration trench, the buried basaltic lava in the vicinity of the silicified tuff was seen. The Neysian and Kahang have oval forms and from inner to outer including phyllic, argillic and propylitic respectively. Most of the argillic alteration zone (with an average diameter $1.5 \mathrm{~km}$ ) is buried under the quaternary alluvium or mixed by sediments. Also, the location of selected samples has been illustrated in Figure 3c.

\section{METHOD OF INVESTIGATION}

Considering the lithological variations in the study area, about 200 samples from altered and accompanying rocks were collected. The laboratory investigations started with the preparation of polished thin sections in Kimia Pajooh Alborz Company, 


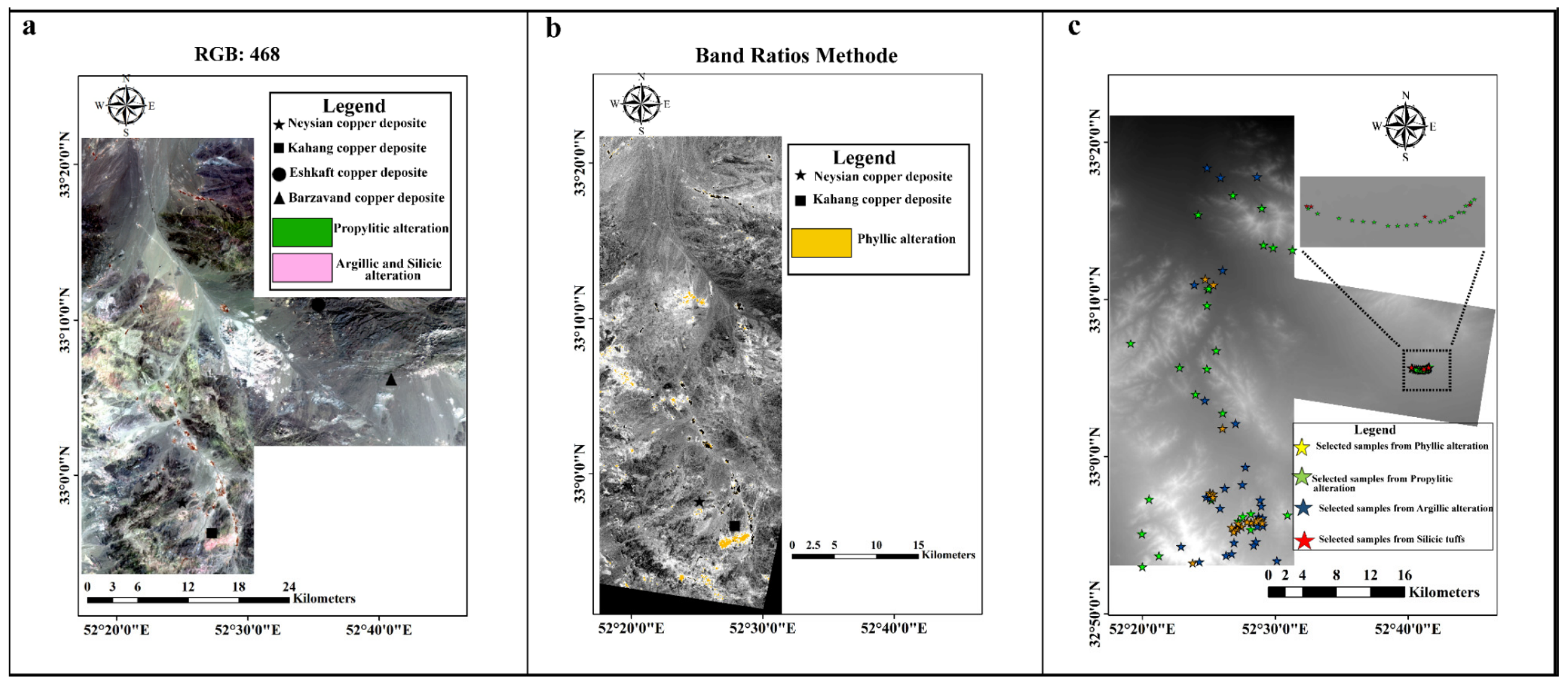

Fig. 3 a) False color composite RGB: 468 on Aster images, argillic and propylitic alterations with pink and green colors, b) Use of $4 / 2$ band ratio to identify the phyllic alteration zone, c) the location of samples of different types of alteration on the DEM images. 
Isfahan-Iran. Fifty polished thin sections were prepared for petrographic examinations (study of polished thin samples carried out by transmission polarizing Olympus microscope, $\mathrm{BH}-2$ model and reflectance polarizing $\mathrm{BX}-60$ model in Isfahan University). Then, two samples were analyzed by XRD method for determination of minerals in the Neysian argillic zone (Faculty of Mining Engineering, Tehran University). Analytical properties were: D8- Advanced model, manufactured by Bruker axes, $\theta$ - $\theta$ type of device with $\mathrm{CuK} \alpha=1.5418 \mathrm{~A}^{\circ} \mathrm{X}$-ray, $2-702^{\circ} \theta$ scanning range and using $40 \mathrm{kV}$ and $30 \mathrm{~mA}$.

The composition of one sample (B2) of Barzavand copper deposit and two samples (K3 and K5) of Neysian argillic zone were determined in 1 and 6 points by electron microscope SEM-EDS (scanning electron microscope- energy dispersive spectroscopy) in Razi Metallurgical Institute, Tehran respectively. To determine the chemical composition of 12 samples in the Barzavand copper deposit (including 10 samples of propylitic basaltic lava, 1 sample of fresh basalt and 1 sample of silicic tuff) analyzed by XRF (for major and minor oxides) and ICP-MS method (for trace and rare earth elements) in Zarazma Laboratory, Tehran. Also, 9 selected samples from fresh volcanic rock and of Neysian copper deposit were analyzed using the XRF method for major and minor oxides. 10 samples of altered rock analyzed by XRF (for major and minor oxides) and ICP- MS (for trace and rare earth elements) method. The 4 samples of altered rock and 1 silicic sample in the Neysian copper deposit were selected and analyzed using the ICP- MS method to determine the amount of REEs.

For the purpose of chemical analysis, all samples were dried at a temperature less than $60{ }^{\circ} \mathrm{C}$ then dried samples were crushed to- 80 mesh and 25 gr was ground (< 150 mesh) by steel ring and puck mill. A total of $0.2 \mathrm{~g}$ of these samples was carefully weighed and $1.5 \mathrm{gr}$ Li-borate/ $\mathrm{Li}_{2} \mathrm{~B}_{4} \mathrm{O}_{7}$ fluxing graphite crucible was added to each sample. These samples were heated at $980{ }^{\circ} \mathrm{C}$ for about 30 minutes. Each sample was dissolved in $100 \mathrm{ml} \mathrm{HNO}_{3}(5 \%)$ and poured into a polypropylene test tube for the measuring process. Chemical analyses were controlled by analyzing the calibration and verification standard. To determine the major and minor oxides in samples, $\mathrm{X}$-ray fluorescence (XRF) and a specific ion electrode (SIE) were used respectively. The detection limit for major and minor oxides was $0.05 \mathrm{wt} . \%$. Trace and rare earth elements identified by ICP-MS method with analytical code (MMS- 01- HF/Multi acid digestive) and (MMS- 02- digestion using HF). For determining trace elements, four acids including $\mathrm{HNO}_{3}, \mathrm{HClO}_{4}$, $\mathrm{HCl}$ and $\mathrm{HF}$ are used. The rare earth elements are a type of refractory elements, so they need stronger extraction analysis with the use of multi-acids and microwave digestion. Then, the final solution was analyzed by ICP- MS.

\section{DISCUSSION}

\subsubsection{GEOLOGY OF THE BARZAVAND COPPER DEPOSIT}

In the Barzavand area, according to evidence of alteration, five exploration trenches excavated and the buried propylitic basalt (host $\mathrm{Cu}$ - bearing minerals) with Oligo- miocene age has been seen (Fig. 4a). In all profiles across basaltic lava, we can see fresh layered tuffs, silicified tuff, argillic alteration with pink color, $\mathrm{Cu}$ - bearing minerals hosted by propylitic basalt and fresh layered tuffs respectively. Under the influence of tectonic stress, the layered tuffs and basaltic lava have found a $70^{\circ}-80^{\circ}$ slope to the north (Figs. 4b, c and d). There is no $\mathrm{Cu}$ mineralization in lower and upper tuff units. The close view of propylitic basalt with $\mathrm{Cu}$-carbonates demonstrated in Figure $4 \mathrm{e}$. The hand- specimen of fresh tuff and silicified tuff (with quartz veinlets) showed in Figures $5 \mathrm{a}$ and $\mathrm{b}$. There is evidence for the presence of spherulite texture (intergrowth of quartz and feldspar with circular forms) in tuff units below basaltic lavas (Figs. 5c and d). This texture formed from devitrification of tuff units under the influence of upper units. The basalt has intense alteration and hosted $\mathrm{Cu}$ - bearing minerals with chlorite and calcite as amygdaloidal texture (Figs. 5e and f). Also, basalts show porphyry texture. In Figure $5 \mathrm{~g}$, there are pyrites with disseminated texture were replaced by goethite but mainly has remained their casts. In some parts, basalts brecciated under influence of tectonic process and filled with $\mathrm{Cu}$ - carbonates as filling cement (Fig. 5h). Malachite veinlet shows in Figure $5 i$. $\mathrm{Cu}$ - carbonates crosscut by $\mathrm{Fe}$ - oxides (Fig. $5 \mathrm{j}$ ). In some hand- specimen, chlorite filled fractures in basalts that crosscut by calcite veinlets (Fig. 5k). Hand- specimen from $\mathrm{Cu}$ - carbonates showed in Figure 51 and $\mathrm{m}$. Silicic veinlets containing $\mathrm{Cu}$ mineralization crosscut by barren silicic veinlets. In silicic tuffs, manganese- oxide veinlets crosscut silicic veinlets (Fig. 5n). Argillic tuffs in pink color with Liesegang structure represented in Figure 5o.

\subsubsection{GEOLOGY OF THE NEYSIAN COPPER DEPOSIT}

In the Neysian area the various types of alteration such as phyllic, advanced argillic, argillic and propylitic are formed. The phyllic alteration is associated with dacite domes and granodiorite bodies (Figs. 6a and b). The argillic alteration zone was flatter than the phyllic zone and affected the volcanic and volcano- sedimentary units. The propylitic alteration zone has formed in basalt and andesite rocks which are located around the Neysian alteration system (Figs. 6a and b). The argillic alteration zone mostly has white, pink, yellow, cream, brown, and red color. Despite occurrence of alteration, the primary bedding of parent rocks has remained (Fig. 6c). The pyroclastic units and argillic alteration zone are seen on both sides of the fault, indicating the important role of faults in decomposition and conversion of pyroclastic units (as a parent rock) into altered products (Fig. 6d). 


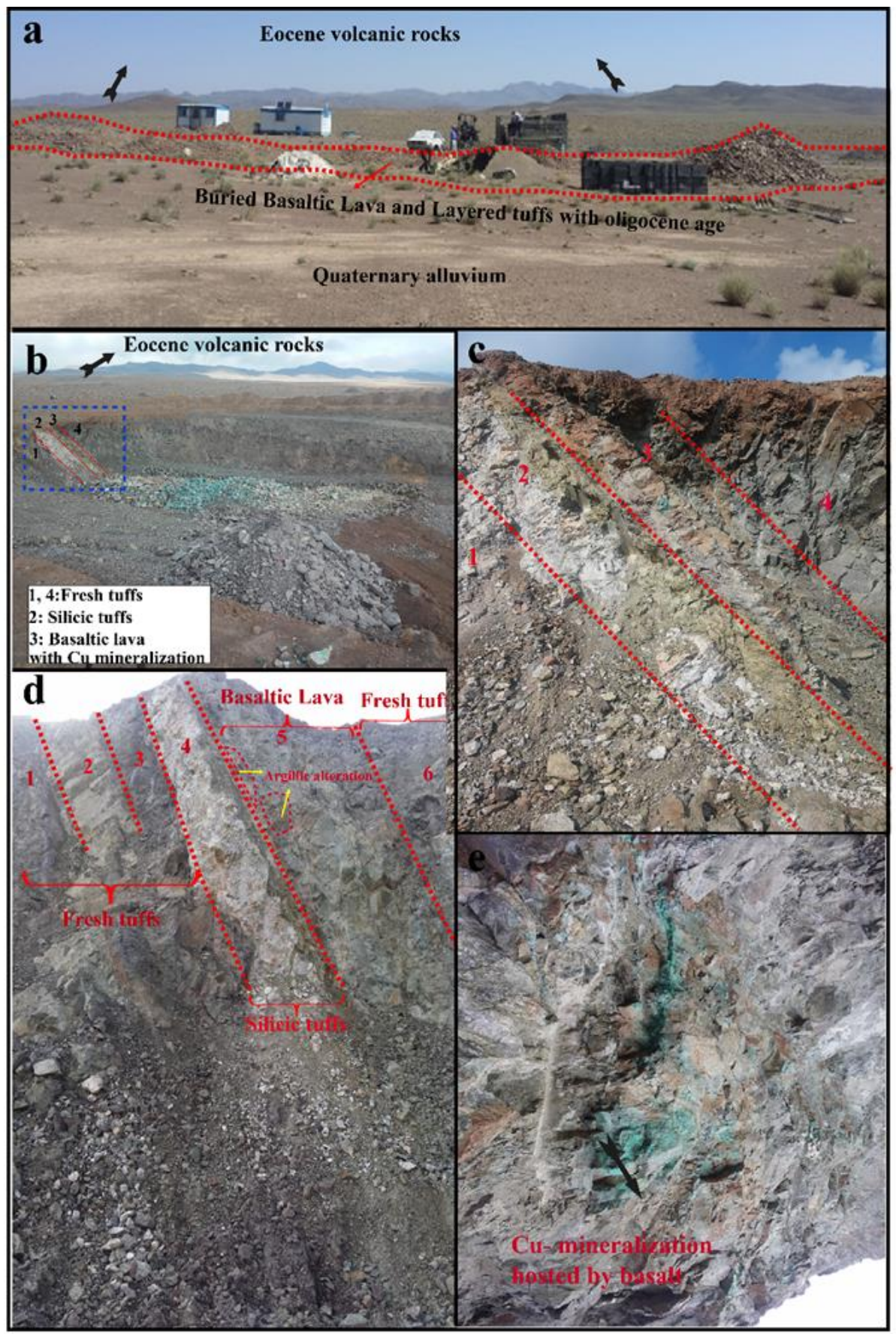

Fig. 4 Field photos of Barzavand copper deposit: a) exploration trench with E- W trend in layered tuff, b) Perspective view from exploration face showing ore deposit depot, c) and d) fresh tuff layers, silicic tuff, non- continous argillic zones and propylitic zone perpendicular to $\mathrm{Cu}$ - bearing veins with 70 to 80 slope to the north, e) close view of basalt hosted $\mathrm{Cu}$ - bearing minerals.

The sample of phyllic alteration zone (in the drilling core) at a depth of $150 \mathrm{~km}$ is shown in Figure 5e. It is related to the sheared zone and the breccia fragments of igneous rocks that attached together with a chalcopyrite matrix (Fig. 6e), but the samples of the phyllic zone near the surface have $\mathrm{Cu}$ carbonates minerals (Fig. 6f). The advanced alteration identified by alunite veinlets in volcanic and volcano-sedimentary host rocks (Fig. 6g). In some parts, trachyandesite was altered to kaolinite and clay minerals and veinlets of quartz, pyrite, jarosite and gypsum crosscut the rock (Fig. 6h). Argillic samples show Liesegang structure (Fig. 6i).

Other important properties of Neysian copper deposit can be pointed out: folding, presence of rounded to angled black chert grains, fresh and semialtered tuff in argillic alteration zone (as a parent rock), presence of red and yellow veinlets of 


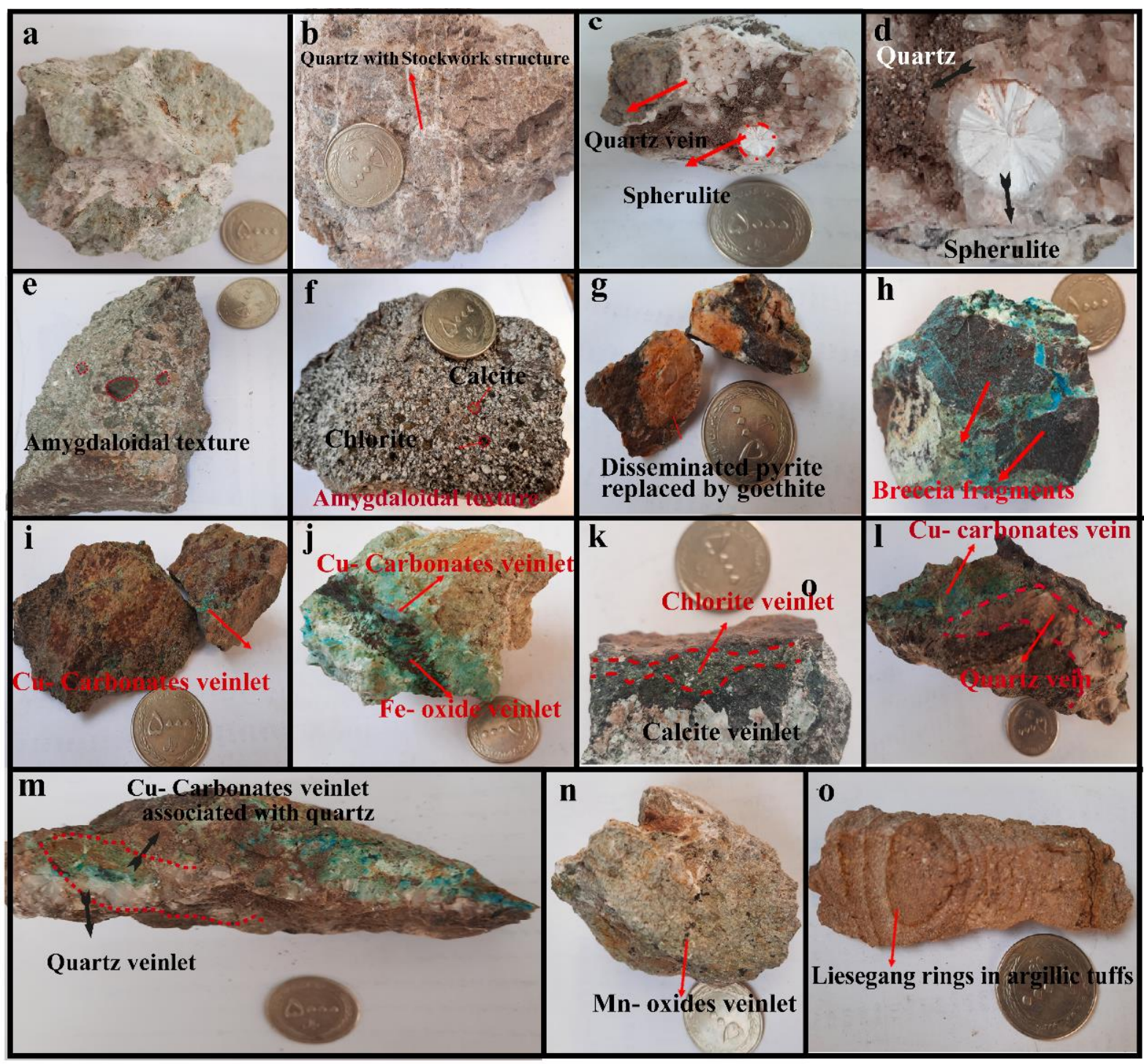

Fig. 5 a) hand specimen of fresh tuff, b) quartz veins in silicic tuff, c) and d) spherulite texture in tuff units below basalt hosted $\mathrm{Cu}$ - bearing minerals, e) and $\mathrm{f}$ ) amygdaloidal texture of chlorite and calcite in basalt cavities (matrix shows porphyry texture), g) pyrite with disseminated texture replaced by goethite, $h$ ) brecciated basalt interlocked with $\mathrm{Cu}$ - carbonate cement, i) Malachite veinlets, j) $\mathrm{Cu}$ - carbonates veinlets crosscut by Fe- Oxides, k) chlorite veinlets crosscut by calcite veinlets, 1) and $\mathrm{m}$ ) basalt lavas including silicic veinlets with $\mathrm{Cu}$ - carbonates crosscut by barren silicic veinlets, Moreover, $\mathrm{Cu}$ - carbonates have filled basalt cavities, n) manganese oxides veinlets crosscut silicic veinlets, o) Liesegang structure in pink- colored argillic tuffs.

Fe- Oxides/hydroxides in yellow- cream, pink and red argillic samples, conchoidal fractures surface and soapy feel in white argillic samples.

\subsection{PETROGRAPHY}

\subsubsection{PETROGRAPHY IN BARZAVAND COPPER DEPOSIT \\ 4.2.1.1 PETROGRAPHY OF SILICIC TUFFS}

The microscopic study demonstrated, silicic tuffs include: plagioclase, sanidine, orthoclase, and quartz crystals (about $50 \%, 7 \%, 8 \%$ and $5 \%$ respectively), volcanic rock fragments (about $5 \%$ ) with opaque minerals (about $3 \%$ ) that surrounding in a volcanic glass matrix (about $22 \%$ ) (Figs. $7 \mathrm{a}$ to c). In some parts, the volcanic glass recrystallized into spherulite (Figs. $7 b$ and c). The spherulite has a circular to semi-circular forms and consist of quartz and feldspar fibers with a feathery texture. In some parts quartz and calcite filling the open spaces between breccia fragments (Fig. 7c). In quartz veinlets, the size of quartz crystals increases from the wall to the center of fractures (Fig. 7d). Finally, the calcite veinlets as the last phase of the alteration process, have cut the silicic veinlets (Fig. 7d). 


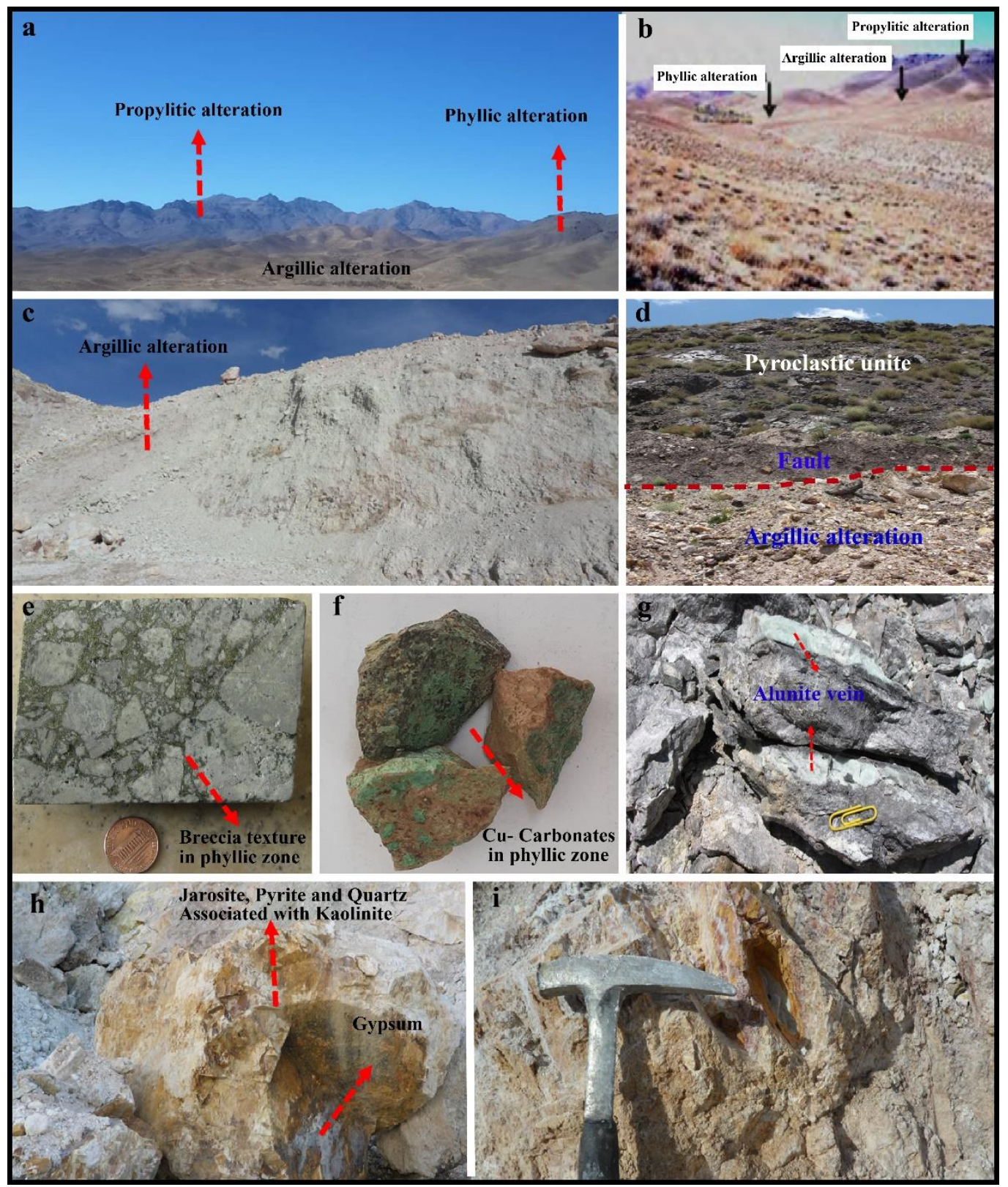

Fig. 6 Field photos of Neysian copper deposit: a) and b) landscape of argillic, phyllic and propylitic alteration in Neysian copper deposit, c) tuff units converted into argillic zone, d) the fault separates the pyroclastic units as parent rock from argillic alteration products, e) breccia texture in phyllic zone at deph of 150 . The granodiorite fragments interlocked with chalcopyrite cement, $\mathrm{f}$ ) $\mathrm{Cu}$ - carbonate minerals in phyllic zone near the surface, $g$ ) the gray alunite veinlets in tuffs, $h$ ) vein of quartz+ jarosite+ pyrite + gypsum in kaolinized trachyandesite, i) liesegang structure in argillic alteration zone.

\subsubsection{PETROGRAPHY OF ARGILLIC TUFFS}

According to mineralogical investigations, the argillic tuffs include minerals such as plagioclase, sanidine, orthoclase, and quartz crystals (about $53 \%$, $7 \%, 8 \%$ and $4 \%$ respectively), volcanic rock fragments (about $5 \%$ ), zeolite and clay minerals (about $11 \%$ ) that surrounded in a volcanic glass matrix (about $12 \%$ ). Plagioclase and volcanic glass matrix as reactivable phases converted into clay minerals (Fig. 7e). In most parts volcanic glass was replaced by platy zeolite and clay minerals (Fig. 7f). The fibrous zeolites fill the cavities (Figs. $7 \mathrm{~g}$ and $\mathrm{h}$ ).

\subsubsection{PETROGRAPHY OF BASALT}

Microscopic examinations show that the basalt in Barzavand copper deposit containing phenocrysts of plagioclase (about $70 \%$ ), olivine (about $5 \%$ ), amphibole (about $2 \%$ ) and opaque minerals (about $3 \%$ ) that surrounded in a microlithic matrix (consist of glass and microphenocrysts of plagioclase (about $20 \%$ ) (Fig. 7i). During the alteration process calcite, zeolite, quartz, and chlorite precipitated. Olivine is replaced by $\mathrm{Fe}$ - oxides and chlorite (Fig. 7j). Also, chlorite, malachite and calcite make open space filling as well as amygdaloidal texture in basalt cavities 


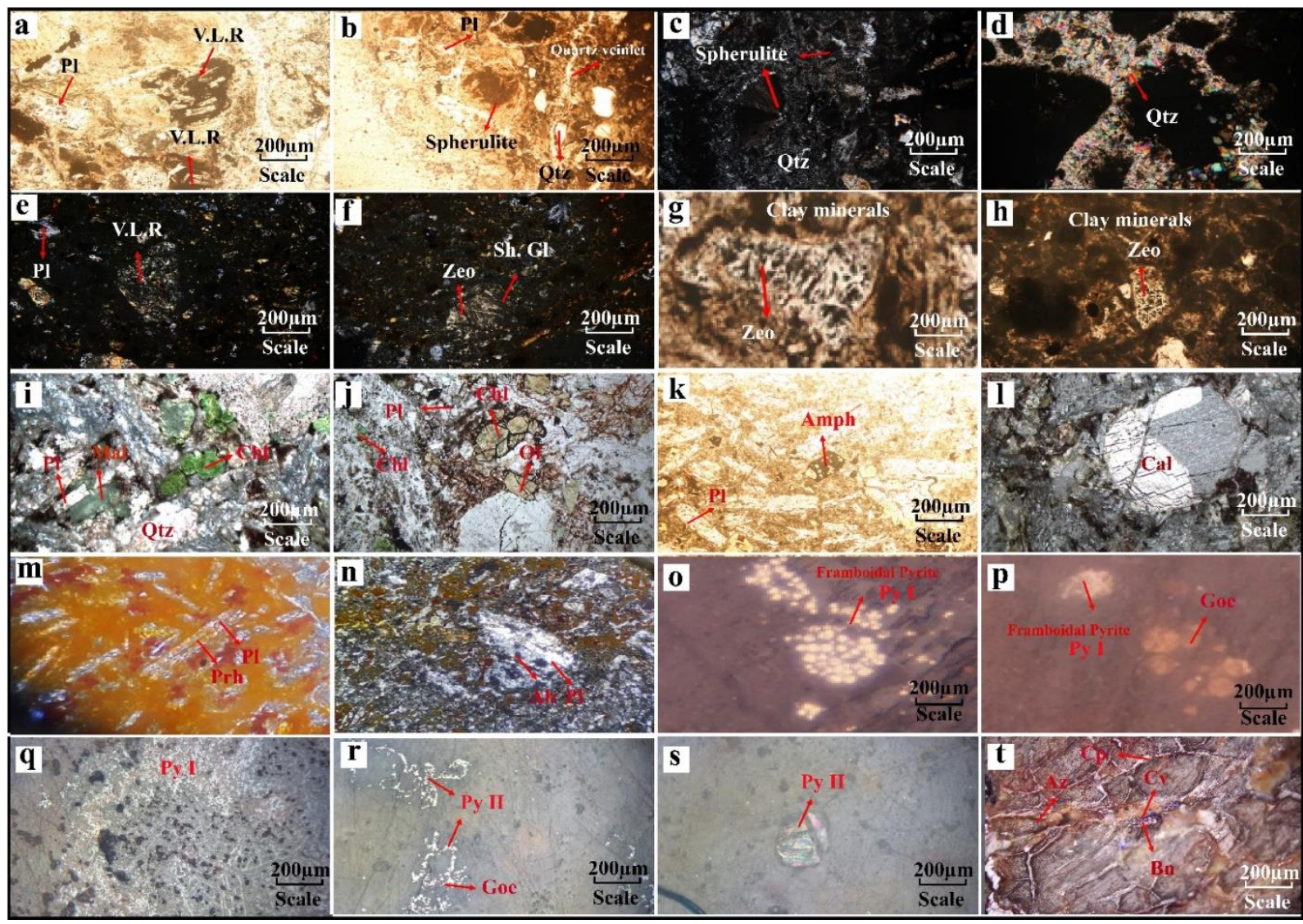

Fig. 7 Photomicrographs of a), b), c) and d): silicic tuffs: a) volcanic rock fragments with plagioclase phenocrysts in volcanic glass matrix (PPL), b) and c) recrystallization of volcanic glass into spherulite. Spherulite have an circular to semi- circular form and composed of quartz and feldspar fibers with feathery texture, broken fragments of plagioclases and quartz vein is visible (XPL), d) veinlet of quartz, the size of quartz crystals increase from wall towards the center of fractures (XPL), e), f) g) and h): argillic tuff e) volcanic rock fragments with plagioclase crystals in fine-grained matrix consist of glass, quartz and plagioclase (XPL), f) replacement of glass by platy zeolites (XPL), g) and h) fibrous zeolite occupied the cavities, glass matrix converted into dark clay minerals (XPL), i), j) k) and l) basalt: i) plagioclase phenocrysts in matrix consist of glass and microphenocrysts of plagioclase, malachite and chlorite filling cavities with amygdaloidal texture (PPL), j) olivine converted into clay minerals and chlorite, also plagioclase partially converted into chlorite (PPL), k) amphibole (form from uralitization of pyroxene) and iddingsite with pseudomorph texture (derived from alteration of olivine and consist of mixtures of olivine, clay minerals and iron oxides) (XPL), 1) calcite with rhombohedral cleavage, filling the basalt cavities (XPL), m) the plagioclase phenocrysts partially replaced by prehnite and calcite (XPL), n) plagioclase partially converted into Na- rich plagioclase during saussuritization (XPL), o), p), q), r), s) and $\mathrm{t}$ ): polished section of basalt: o) and $\mathrm{p}$ ) the framboidal pyrite replaced by goethite, q) disseminated pyrite and veinlets of pyrite, $r$ ) cholloform pyrite, $s$ ) euhedral pyrite, $t$ ) veinlets of chalcopyrite and bornite replaced by covellite and azurite. In some parts, the fine grains of primary pyrite have remained in chalcopyrite veinlets and hematite.

Zeo $=$ Zeolite, $\mathrm{Pl}=$ Plagioclase, $\mathrm{Qtz}=\mathrm{Quartz}, \mathrm{V} . \mathrm{L} . \mathrm{R}=$ Volcanic lithic rock, $\mathrm{Cl}=\mathrm{Clay}$ minerals, $\mathrm{Cal}=\mathrm{Calcite}, \mathrm{Chl}=\mathrm{Chlorite}$, $\mathrm{Amph}=$ Amphibole, $\mathrm{Py}=$ Pyrite, $\mathrm{Cp}=$ Chalcopyrite, $\mathrm{Bu}=$ Burnite, $\mathrm{Cv}=$ Covellite, $\mathrm{Az}=$ Azurite, Mal $=$ Malachite and $\mathrm{Goe}=$ Goethite. (Abbreviation of minerals from Kretz (1983) and Whitney and Evans (2010)). All Photomicrographs from Barzavand copper deposit.

(Fig. 7j). Iddingsite with pseudomorph texture, derived from the alteration of olivine and consist of mixtures of olivine, clay minerals and iron oxides. It forms from alteration and weathering of basalt in presence of meteoric water (Fig. 7k). During uralitization alteration, amphiboles form from pyroxene (Fig. 7k). Calcite with clear rhombohedral cleavage, filling the basalt cavities (Fig. 71). Also, the plagioclase phenocrysts often saussuritized and are partially replaced by prehnite, calcite (Fig. $7 \mathrm{~m}$ ) and sodium- rich plagioclase (Fig. 7n).

The framboidal pyrite replaced by goethite (Figs. 7o and p). Fine-grained pyrite with disseminated texture has filled fractures and cavities 
Table 1 The paragenetic sequence of mineralization in Barzavand copper deposit.

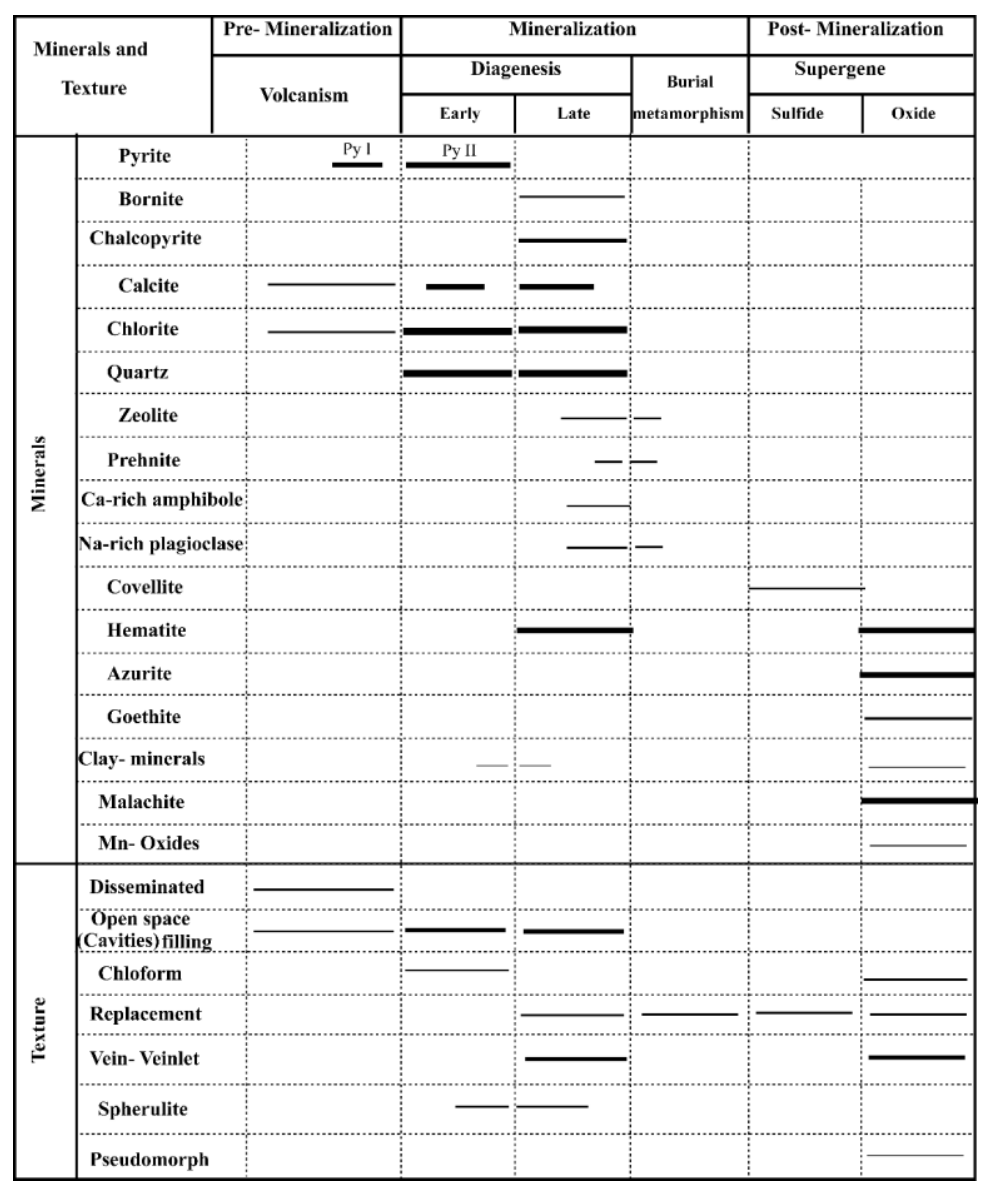

(Fig. 7q). The colloform pyrites converted into goethite (Fig. 7r). It seems that euhedral pyrite has been formed by recrystallization of syngenetic disseminated pyrites (Fig. 7s). The veinlets of chalcopyrite are visible. Bornite replaced by covellite. Chalcopyrite and bornite can be converted into covellite, malachite and azurite during the supergene process (Fig. 7t). In some parts, the fine grains of primary pyrite have remained in hematite (Fig. 7t).

The paragenetic sequence of mineralization listed in Table 1. In the Barzavand copper deposit, the pyrite plays an important role in ore precipitation. The framboidal, syngenetic disseminated and open space filling pyrite can be classified as first generation pyrite (py1). Precipitation of disseminated pyrite occurs with volcanism activity and eruption of basalt at the same time. The colloform and euhedral pyrite are classified as second generation pyrite (py2). By increasing the thickness of the tuffs, basin subsidence, and geothermal activity in tension Barzavand basin, early and late diagenesis processes have occurred. This stage, accompanied by the entrance of metal- rich fluids into the reduced host rock caused the replacement for the first stage pyrites with copper sulfides and hematite (Table 1). According to the mineralogical study, three main stages can be considered during the formation of the Barzavand copper deposit:

1) Pre mineralization (volcanism): First stage includes volcanic activity and eruption of basalt lava and tuffs. Propylitization has occurred by the interaction of seawater and basalt. During the host rock deposition, disseminated pyrite formed under reducing conditions resulting from sulfate- reducing bacteria activity. The $\mathrm{H}_{2} \mathrm{~S}$ is produced by sulfate-reducing bacteria in the host rock. Pyrite formed by interaction between the generated $\mathrm{H}_{2} \mathrm{~S}$ and seawater $\mathrm{Fe}$ cations. Generally, the first generation pyrite, chlorite and calcite precipitated in this stage (Table 1).

2) Mineralization stage: Including early and late diagenesis and burial metamorphism. In the early diagenesis stage precipitated the colloform and euhedral pyrite, calcite and chlorite minerals. During the late diagenesis stage, brine fluids derived from related diagenesis of the pyroclastic sequence leached out copper from ferromagnesian minerals (such as biotite, olivine, amphibole, pyroxene) and volcanic rock fragments then redeposit the metals in basalt rock. Ore- bearing basalt contains disseminated syngenetic pyrite, such pyrites provide a localized reducing environment and promoting sulfide 


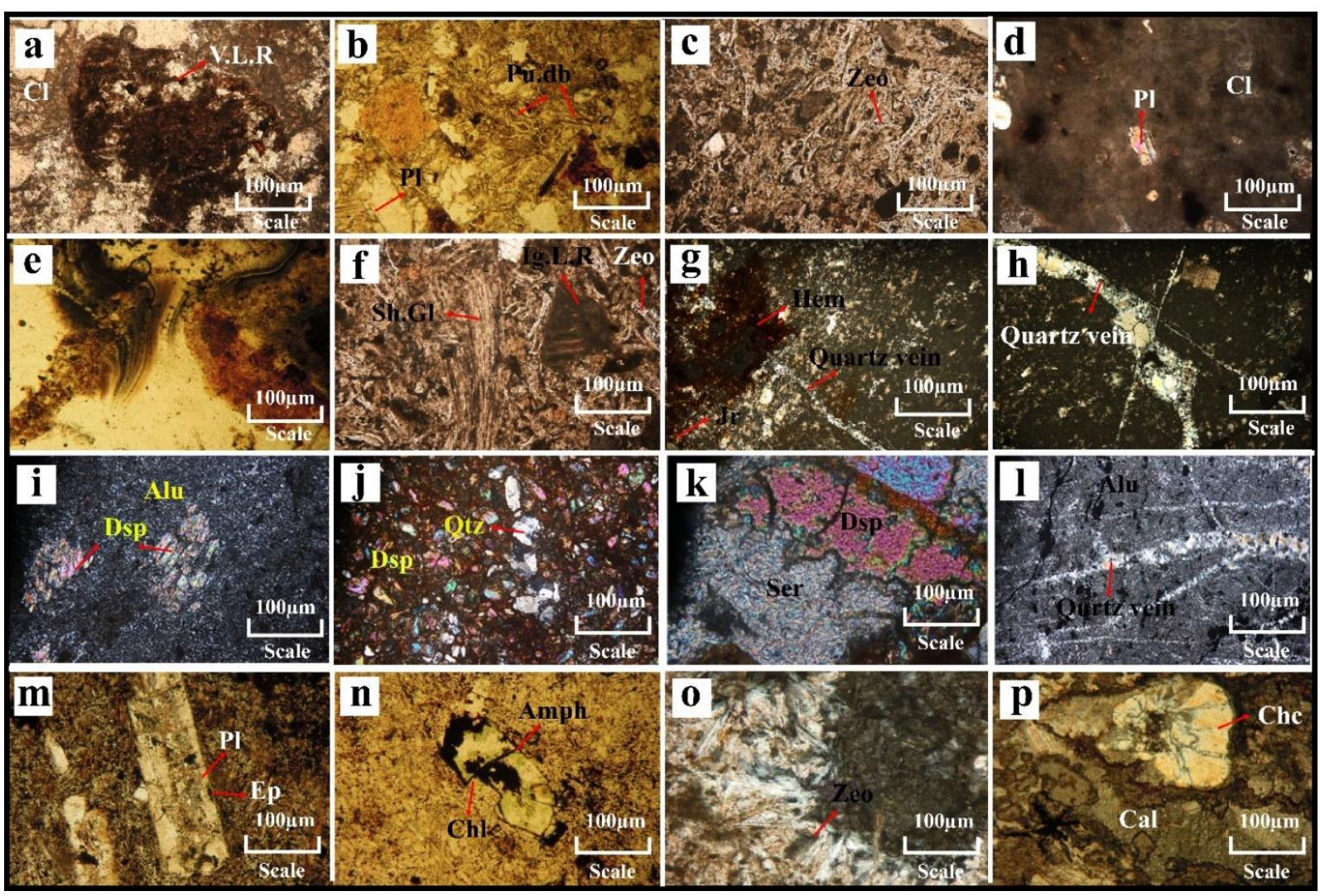

Fig. 8 Photomicrographs of a), b), c) and d): tuffs: a) the volcanic lithic rocks consist of plagioclase phenocrysts and broken amphibole crystals replaced by $\mathrm{Fe}$ - oxides in matrix of plagioclase microphenocrysts and glass, b) plagioclase crystals with pumice debris, c) conversion of volcanic glass into zeolite and d) the plagioclase phenocryst in clay matrix without argillitization, e) and f): ignimbrites: e) directed volcanic glass in clay matrix, f) broken plagioclase, zeolite and directed glass, g) and h) trachyandesite: veinlet of quartz+ pyrite+ jarossite+gypsum in kaolinized trachyandesite, i), j), k) and l) advanced argillic alteration: i) plagioclase phenocrysts replaced by diaspore, j) coarse- grained quartz crystals and diaspore, $\mathrm{k}$ ) conversion of sericite into diaspore, l) quartz with stockwork texture in alunite matrix with disseminated texture, m), n), o) and p) propylitic alteration: m) plagioclase phenocryst replaced by epidote, $n$ ) replacement of amphibole by chlorite, o) Cavities occupied by zeolite, p) Cavities occupied by fibrous chalcedony, All pictures prepared in XPL.

Zeo $=$ Zeolite, $\mathrm{Pl}=$ Plagioclase, $\mathrm{Qtz}=\mathrm{Quartz}, \mathrm{V} . \mathrm{L} . \mathrm{R}=$ Volcanic lithic rock, $\mathrm{Cl}=$ Clay minerals, $\mathrm{Cal}=\mathrm{Calcite}, \mathrm{Chl}=\mathrm{Chlorite}$, $\mathrm{Amph}=$ Amphibole, Chc= Chalcedony, Dsp=Diaspore, Ser= Sericite, Alu= Alunite, Ig. L. R= Ignimbrite lithic rock, Pu.Db= Pumice debris and Sh.Gl= Shard glass. (Abbreviation of minerals from Kretz (1983) and Whitney and Evans (2010)). All Photomicrographs from Neysian copper deposit.

precipitation. $\mathrm{Cu}$ - bearing sulfides precipitated mainly in veins where $\mathrm{Cu}$ - bearing brine diagenesis fluids mixed by syngenetic pyrites. Pyrite are partially replaced by copper sulfides. Also, the primary plagioclase is replaced by prehnite and sodium- rich plagioclase. It seems that Saussuritization and uralitization occurred due to entrance of $\mathrm{Na}$ and $\mathrm{Ca}-$ rich late- stage brain fluids into basalt host rock. Precipitation of zeolite and prehnite can be related to weak metamorphism processes (Kojima et al., 2009). Hematite is derived from the breakdown of unstable iron- rich minerals such as pyroxene and amphibole in volcanic rocks (Walker et al., 1978).

3) Post mineralization stage: The tectonic movements cause exposure of altered rocks, formation of fractures in the near- surface parts of the deposit, penetration of oxide meteoric water and evolution of the supergene process. Supergene processes include the predominance of meteoric water circulation with concomitant oxidation and chemical weathering. In this stage bornite converted into covellite, chalcopyrite and bornite were replaced by malachite and azurite, also pyrite converted into hematite and goethite. Biotite, plagioclase and volcanic glass were replaced by clay minerals. The dissolution of pyrite in the host rock can increase the fluid acidity. Clay minerals are formed during the interaction between suitable and reactivable phases (such as volcanic glass and plagioclase) and descending meteoric water. Also, the resistant minerals such as olivine and pyroxene show less decomposition and mostly remain intact from the alteration process. 


\subsubsection{PETROGRAPHY IN NEYSIAN COPPER DEPOSIT 4.2.2.1 PETROGRAPHY OF ARGILLIC ALTERATION ZONE}

In the Neysian area the argillic alteration extended in tuffs, ignimbrite, and volcanic rocks.

a) Tuffs: Microscopic study demonstrated, tuffs include plagioclase, quartz crystals (about $57 \%$ and $15 \%$ ), volcanic rock fragments (about $7 \%$ ) and zeolite and pumice debris (about $3 \%$ ) crystals in microlithic matrix (about $18 \%$ ). Phenocrysts of plagioclase are dispersed in a glass matrix and mostly converted into clay minerals and $\mathrm{Fe}$ - oxides/ hydroxides (Figs. 8a to d). The volcanic rock fragments have a porphyry texture including dispersed phenocrysts of plagioclase and biotite in a fine-grained matrix of microlite and glass. The matrix replaced by clay minerals and Fe- oxides/ hydroxides (Fig. 8a).

Pumice debris is distinguished by its vesicular form. These vesicular forms have initially been circular, but after exerting tectonic stress deformed into oval form (Fig. 8b). Pumice debris converted into clay minerals but the early vesicular forms have remained. Shard glass replaced by zeolite (Fig. 8c). With increasing intensity of the alteration process, more clay minerals (with dark colors) are produced and phenocrysts of plagioclase have been seen in the clay matrix (Fig. 8d). Shard glass, volcanic glass matrix and pumice debris as an nonresistant phase are converted into clay minerals but other minerals with higher resistance, remain as residual minerals in a dense fraction of weathering products (Fatahi et al., 2020).

b) Ignimbrite: Microscopic examinations show that ignimbrite contains plagioclase, quartz, zeolite and chalcedony crystals (about $60 \%, 5 \%, 2 \%, 5 \%$ ), volcanic rock fragment (about $5 \%$ ) and directed volcanic glass (about $23 \%$ ) (Figs. 8e and f). In some parts dispersed fine broken fragments of plagioclase are visible (Fig. 8f). Directed volcanic glass and plagioclase are exposed to alteration.

c) Trachyandesite: Microscopic studies show that the trachyandesite include: plagioclase (about $60 \%$ ), sanidine (about $8 \%$ ), amphibole (about $4 \%$ ) pyroxene (about $3 \%$ ), biotite (about $2 \%$ ) and opaque minerals (about $5 \%$ ) that surrounded in microlithic matrix (about $18 \%$ ). The microlithic matrix is converted into clay minerals and Fe-oxides. Veinlets of quartz, pyrite, jarosite, and hematite cut the rock (Figs. $8 \mathrm{~g}$ and $\mathrm{h}$ ). The size of quartz crystal has increased from wall rock towards the center of the veinlet (Fig. 8h).

\subsubsection{PETROGRAPHY OF ADVANCED ARGILLIC ALTERATION ZONE}

In microscopic studies, diaspore is seen in three different forms and the feldspar phenocrysts replaced by diaspore (Fig. 8i). It seems that decomposition of magmatic feldspar provides aluminum requirements to form diaspore phenoblasts. In some parts, diaspore accompanied by quartz crystals as alteration products (Fig. 8j). Also, dispersed diaspore observed in sericite matrix with unequilibrium border (Fig. 8k). Sericite has resorbed margins and it seems that diaspore formed from decomposition of sericite. In some parts, fine- grained alunite with pervasive texture can be seen. Despite the alteration process, the primary porphyry texture of the parent rocks has been remained. Also, in some parts, quartz veinlet has cut the alunite matrix (Fig. 81).

\subsubsection{PETROGRAPHY OF PROPYLITIC ALTERATION ZONE}

Andesitic and basaltic rocks are exposed to propylitic alteration. Microscopic studies indicate that epidote, chlorite, calcite and chalcedony are reactive products of propylitic samples (Figs. $8 \mathrm{~m}$ to $\mathrm{p}$ ). Plagioclase phenocrysts and amphiboles converted into epidote and chlorite respectively (Figs. $8 \mathrm{~m}$ and $\mathrm{n}$ ). Cavities occupied by zeolite and fibrous chalcedony (Figs. 8o and p respectively).

\subsubsection{PETROGRAPHY OF PHYLLIC ALTERATION ZONE}

The phyllic alteration zone extends in granodiorite stocks. The microscopic examination of granodiorite indicates plagioclase phenocrysts, quartz, alkali feldspars (about 25\%,30\%, $10 \%$ respectively), biotite and amphibole (about $5 \%$ ) in microlithic matrix composed of quartz (about $5 \%$ ), plagioclase microphenocrysts (about $15 \%$ ) and volcanic glass (about $10 \%$ ). Sericite can be seen in three forms: 1) intergranular texture with quartz crystals (Fig. 9a), 2) alteration product of plagioclase (Fig. 9b), and 3) as microlithic matrix decomposition (Fig. 9c). Malachite has stockwork texture and precipitated in host rock fractures (Figs. 9d to f) or occupy the cavities with boxwork texture (Fig. 9g). Goethite occurs in a colloform texture. More accurate studies show disperse fine - grained pyrite and chalcopyrite remain in goethite and rock matrix (Figs. 9f to $h$ ). In some parts, pyrite is converted into Fe oxides/ hydroxides (Figs. 9h and i).

\subsubsection{XRD DETERMINATIONS}

The results of XRD studies of two samples from argillic alteration zone indicate that kaolinite, quartz, calcite and alunite are major phases that are accompanied by minor phases such as illite, albite, montmorillonite, sanidine, orthoclase and hematite (Figs. 10a and b).

\subsubsection{SEM DETERMINATIONS}

According to presence of gold $>2 \mathrm{ppm}$ in $\mathrm{B} 2$ sample (from Barzavand copper deposit), this sample prepared for SEM - EDS analysis. Ag - Au solid solution have been observed in spot 1 (Fig. 11). In order to detect clay minerals composition and other minor minerals, samples from the argillic alteration zone are prepared for SEM-EDS analysis. $\mathrm{Cu}-\mathrm{Zn}$ oxides- bearing minerals absorbed by smectite surface (Fig. 12a). Also, the analysis of montmorillonite 


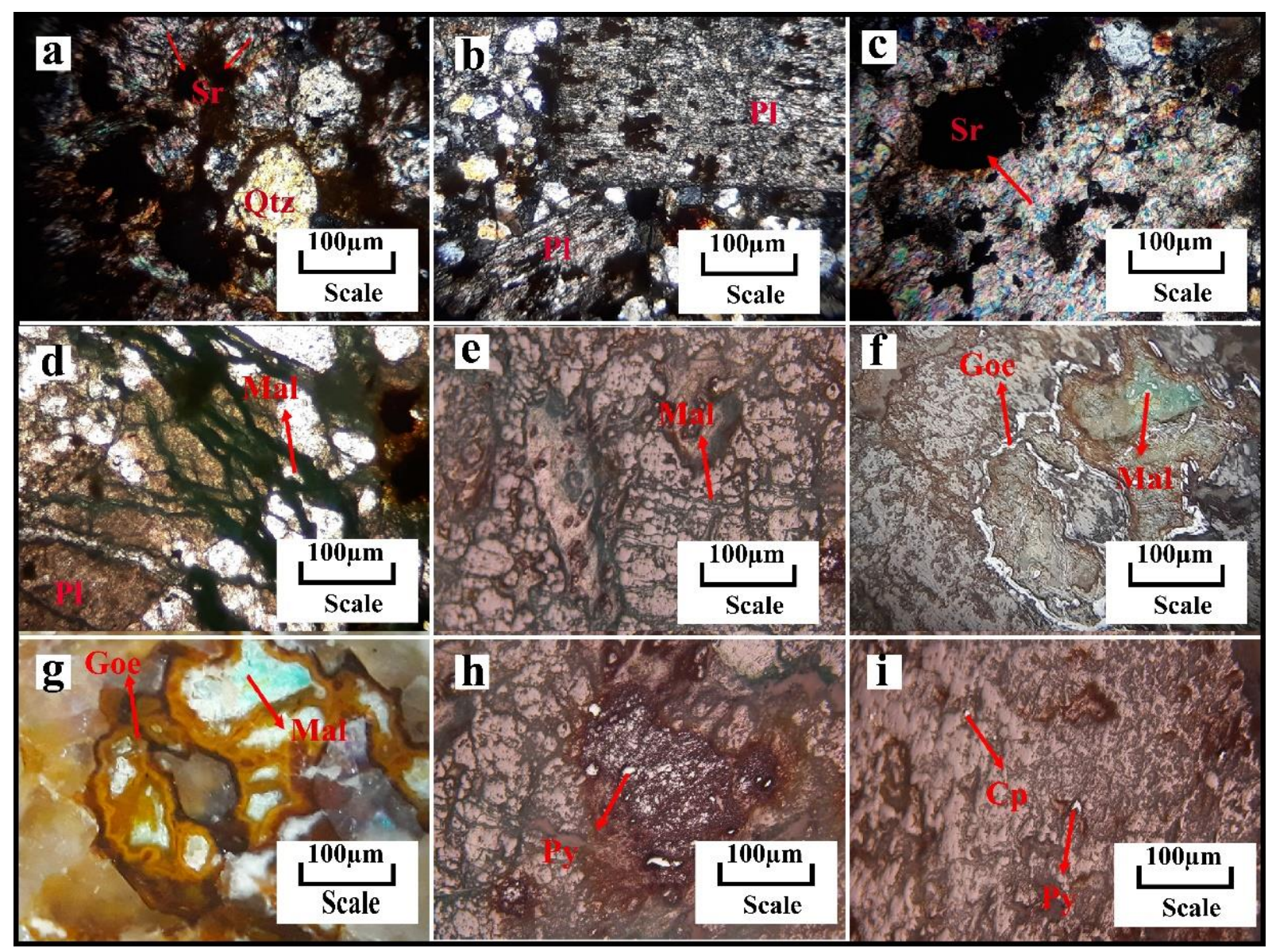

Fig. 9 Photomicrographs of granodiorite with phyllic alteration: a) intergranular sericite in quartz crystals $(\mathrm{XPL}), \mathrm{b})$ complete replacement of plagioclase by sericite (XPL), c) matrix replaced by coarse-grained sericite (XPL), d) the veinlets of quartz and malachite cut the plagioclase crystals and matrix with stockwork texture, e) malachite with stockwork texture, f) and g) goethite with colloform texture, fine-grained pyrite remains in goethite, malachite fill cavities with boxwork texture, h) conversion of pyrite into $\mathrm{Fe}$ - oxides/ hydroxides, i) fine-grained pyrite and chalcopyrite with disseminated texture.

$\mathrm{Pl}=$ Plagioclase, $\mathrm{Qtz}=\mathrm{Quartz}, \mathrm{Ser}=$ Sericite, $\mathrm{Py}=\mathrm{Pyrite}, \mathrm{Cp}=$ Chalcopyrite, Goe= Goethite and Mal= Malachite. (Abbreviation of minerals from Kretz, 1983 and Whitney and Evans, 2010). All Photomicrographs from Neysian copper deposit.

indicates the presence of $\mathrm{Ca}, \mathrm{Na}$ and $\mathrm{K}$ (Fig. 12a). $\mathrm{Ca}$, $\mathrm{Na}$ and $\mathrm{K}$ are assigned to an exchangeable site in montmorillonite (Christidis, 2008).

Image of layered smectite was showed in Figure 12b. The spectral analyses show $\mathrm{Ca}$ and $\mathrm{Cs}$ in montmorillonite composition. It indicates the presence of these cations in the interlayer site of montmorillonite lattice. Also, $\mathrm{Pb}$ - bearing minerals, monazite and barite are identified (Figs. 12c to e). Cesium as a large ion element, commonly substituted for $\mathrm{K}$ in various mineral lattices. Absorption of $\mathrm{Cs}$ in montmorillonite lattice from the aspect of $\mathrm{C}$ - axis and octahedral cation charge considered by Eliason (1996). Smectite with suitable interlayered sites can absorb Cs during formation. Exit the ferric iron from the environment and substitution of $\mathrm{Al}$ for $\mathrm{Si}$ in montmorillonite causes a negative charge in the octahedral site. It can be effective on cesium adsorption.
Adsorption of $\mathrm{Cu}-\mathrm{Zn}$ and $\mathrm{Pb}$ - bearing minerals by montmorillonite in argillic alteration zone can be considered as exploration target to find potential resources of metals in Neysian. Also, presence of cesium in montmorillonite lattice and monazite indicate the scientific significance of study area for exploration of trace and rare earth elements. Stoichiometric coefficient values calculated based on EDS analyses and 11 oxygen (Christidis, 2008) (Table 2). The chemical composition of smectite in two points of Neysian argillic zone listed in Table 3. The identified minerals in different alteration zone are provided in Table 4.

Argillic, phyllic and propylitic alteration maps in study area based on field and mineralogical studies in Figures 13a to d. As seen, precipitation of $\mathrm{Cu}$ - bearing minerals in Neysian and Barzavand copper deposits, complies with phyllic and propylitic alteration zones. Alteration map of NW- Naein and $\mathrm{Cu}$ - concentration changes show in Figures 14a and b respectively. 

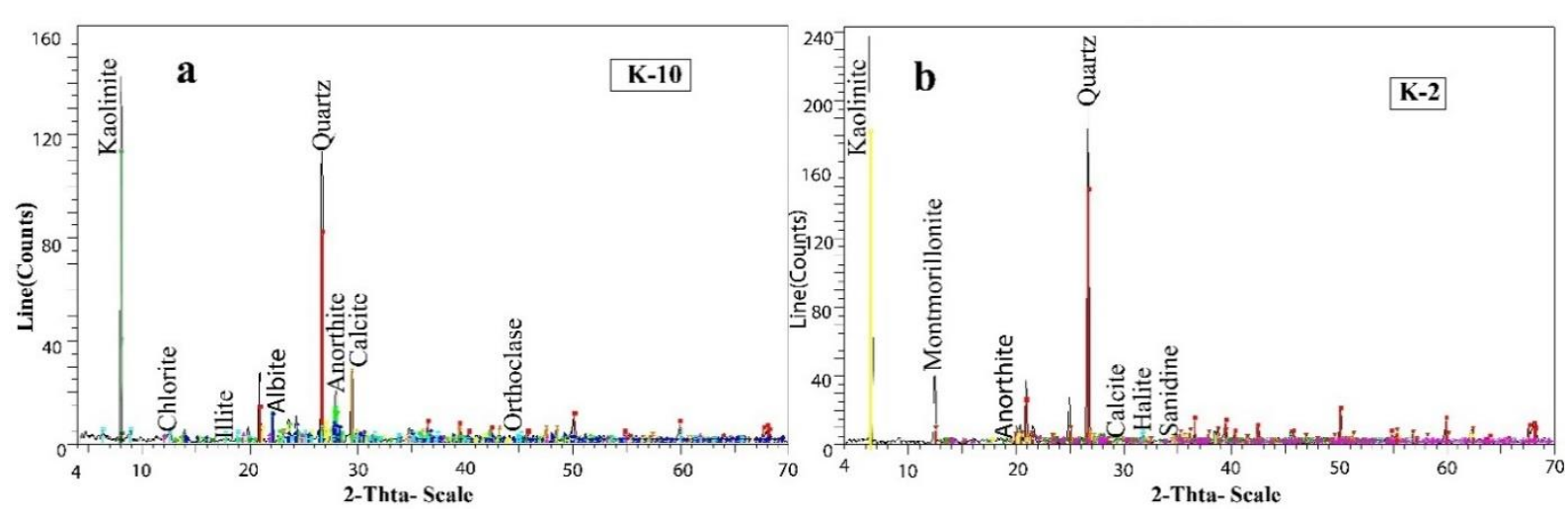

Fig. 10 XRD patterns of two kaolin samples from Neysian copper deposit: a) K-10 and b) K-2 respectively.
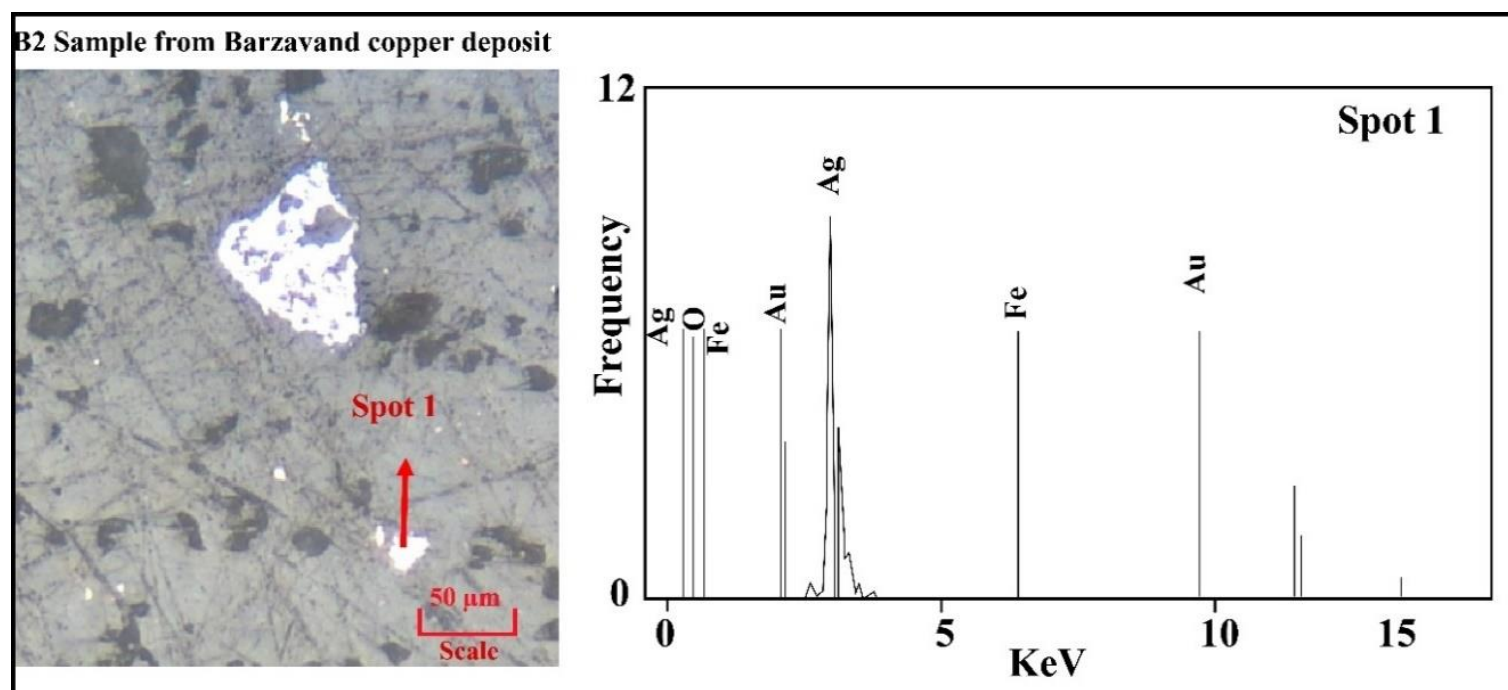

Fig. 11 SEM image of B2 sample from Barzavand copper deposit, indicate analyzed points and results. Ag - Au solid solution have been observed in spot 1 .

Table 2 Stoichiometric coefficient values calculated based on EDS analyses and 11 oxygen (Christidis, 2008).

\begin{tabular}{lccccccc}
\hline & $\mathbf{S i}$ & $\mathbf{A l}(\mathbf{I V})$ & $\mathbf{A l}(\mathbf{V I})$ & $\mathbf{N a}$ & $\mathbf{M g}$ & $\mathbf{C a}$ & $\mathbf{C s}$ \\
\hline Spectrum 2 & 3.6400 & 0.3599 & 1.8479 & 0.3509 & 0.0830 & 0.6897 & 0.0000 \\
Spectrum 3 & 3.6609 & 0.3391 & 1.6129 & 0.0000 & 0.0000 & 1.2443 & 0.0293 \\
\hline
\end{tabular}

Table 3 The chemical composition of smectite in two points of Neysian argillic alteration zone.

Point of analyse Structural formula

\begin{tabular}{lr}
\hline Spectrum 2 & $\left(\mathbf{C a} \mathbf{a}_{0.6897} \mathbf{N a}_{0.3509}\right)\left(\mathbf{A l}_{1.8479} \mathbf{M g}_{0.0830}\right)\left(\mathbf{S i}_{3.6400} \mathbf{A l}_{0.3599} \mathbf{O}_{10}\right)(\mathbf{O H})_{2}$ \\
Spectrum 3 & $\left(\mathbf{C a}_{1.2443} \mathbf{C s}_{0.0293}\right)\left(\mathbf{A l}_{1.6129}\right)\left(\mathbf{S i}_{3.6609} \mathbf{A l}_{0.3391} \mathbf{O}_{10}\right)(\mathbf{O H})_{2}$ \\
\hline
\end{tabular}

Table 4 Distribution of minerals in different types of alteration zone in Neysian copper deposit.

\begin{tabular}{lll}
\hline $\begin{array}{l}\text { Types of } \\
\text { alteration }\end{array}$ & \multicolumn{1}{c}{ Minerals } & \multicolumn{1}{c}{$\begin{array}{c}\text { Converted phase to } \\
\text { alteration }\end{array}$} \\
\hline Argillic & $\begin{array}{l}\text { Montmorillonite, Cs- bearing Momtmorillonite plagioclase, } \\
\text { zeolite, biotite, quartz, calcite, hematite, jarosite, pyrite, } \\
\text { kaolinite, gypsum, barite, monazite, }(\mathrm{Cu}-\mathrm{Zn})-\text { bearing } \\
\text { minerals and } \mathrm{Pb} \text { - bearing minerals }\end{array}$ & $\begin{array}{l}\text { Shard glass, pumice debris } \\
\text { and plagioclase, }\end{array}$ \\
\hline Advanced argillic & Diaspore and alunite & Plagioclase \\
\hline Phyllic & Sericite, quartz, chalcopyrite, malachite, azurite and pyrite & Plagioclase \\
\hline Propylitic & Chlorite, calcite, chalcedony and epidote & $\begin{array}{l}\text { Plagioclase, amphibole, } \\
\text { olivine and biotite }\end{array}$ \\
\hline
\end{tabular}




\begin{tabular}{|c|c|c|c|}
\hline 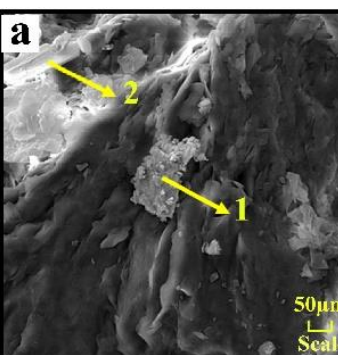 & $\begin{array}{l}\text { Elements } \\
\text { Oxygen } \\
\text { Magnesium } \\
\text { Aluminum } \\
\text { Calcium } \\
\text { Silicon } \\
\text { Sodium } \\
\text { Chlorine } \\
\text { Iron } \\
\text { Copper } \\
\text { Einc }\end{array}$ & $\begin{array}{c}\text { Spectrum 1 } \\
3.6 \\
1.2 \\
0.85 \\
- \\
1.15 \\
- \\
1.42 \\
0.79 \\
43.26 \\
29.53\end{array}$ & $\begin{array}{c}\text { Spectrum 2 } \\
39.04 \\
0.44 \\
10.87 \\
6.03 \\
22.29 \\
1.76 \\
- \\
- \\
- \\
-\end{array}$ \\
\hline 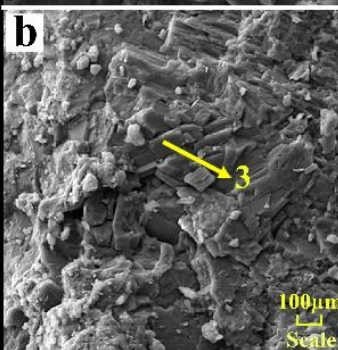 & $\begin{array}{l}\text { Carbon } \\
\text { Oxygen } \\
\text { Aluminum } \\
\text { Silicon } \\
\text { Calcium } \\
\text { Cesium }\end{array}$ & 7 & $\begin{array}{c}\text { Spectrum } 3 \\
1.70 \\
27.30 \\
9.92 \\
23.43 \\
11.37 \\
0.89\end{array}$ \\
\hline c & $\begin{array}{l}\text { Oxygen } \\
\text { Aluminium } \\
\text { Silicon } \\
\text { Sulfur } \\
\text { Lead }\end{array}$ & & $\begin{array}{c}\text { Spectrum } 4 \\
27.86 \\
3.36 \\
3.34 \\
0.01 \\
51.31\end{array}$ \\
\hline 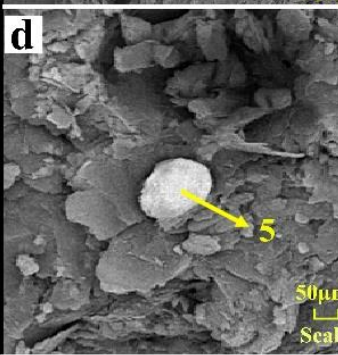 & $\begin{array}{l}\text { Carbon } \\
\text { Oxygen } \\
\text { Aluminum } \\
\text { Silicon } \\
\text { Phosphorus } \\
\text { Lanthanum } \\
\text { Cerium }\end{array}$ & & $\begin{array}{c}\text { Spectrum 5 } \\
2.73 \\
35.98 \\
0.77 \\
1.09 \\
11.92 \\
10.77 \\
22.70\end{array}$ \\
\hline 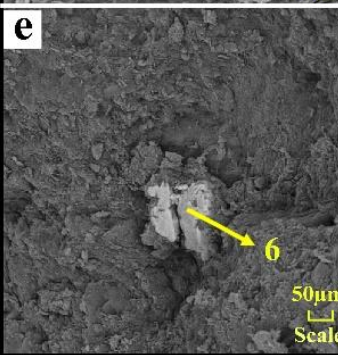 & $\begin{array}{l}\text { Carbon } \\
\text { Oxygen } \\
\text { Aluminum } \\
\text { Silicon } \\
\text { Sulfur } \\
\text { Barium }\end{array}$ & & $\begin{array}{c}\text { Spectrum } 6 \\
2.60 \\
34.30 \\
3.90 \\
4.45 \\
10.33 \\
33.84\end{array}$ \\
\hline
\end{tabular}

Fig. 12 SEM images of argillic alteration zone from Neysian copper deposit, indicate analyzed points and results: a) montmorillonite adsorb ( $\mathrm{Cu}-\mathrm{Zn}$ )- bearing minerals, b) montmorillonite with $\mathrm{Cs}$ and $\mathrm{Ca}$ as intelayer cations, c) montmorillonite adsorb $\mathrm{Pb}$ - bearing minerals, d) monazite, e) barite.

\subsection{GEOCHEMISTRY}

\subsubsection{GEOCHEMICAL STUDY IN BARZAVAND ALTERATION SYSTEM}

The results of geochemical analyses are listed in Tables 5 and 6. In order to explain the behavior of elements during alteration processes, the normalized diagrams of major, minor and trace elements to fresh basalt are shown in Figures 5 a and b. Also, rare earth elements normalized to Chondrite (Sun and McDonough, 1989) (Fig. 5c). Finally, the normalized diagrams of major and minor oxides, trace and rare earth elements to ocean ridge basalt (Sun and McDonough, 1989) are shown in Figures $15 d$ to f. The value of $\mathrm{Eu}$ and $\mathrm{Ce}$ anomalies, $(\mathrm{La} / \mathrm{Lu})_{\mathrm{N}},(\mathrm{La} / \mathrm{Sm})_{\mathrm{N}}$, $(\mathrm{La} / \mathrm{Yb})_{\mathrm{N}},(\mathrm{Gd} / \mathrm{Yb})_{\mathrm{N}}, \mathrm{La} / \mathrm{Y}, \quad \sum \mathrm{LREE}, \sum \mathrm{HREE}$ and $\sum \mathrm{REE}$ are listed in Table 7.

\subsubsection{MAJOR AND MINOR OXIDES}

The results show that the major and minor oxides have three different behaviors during the alteration 


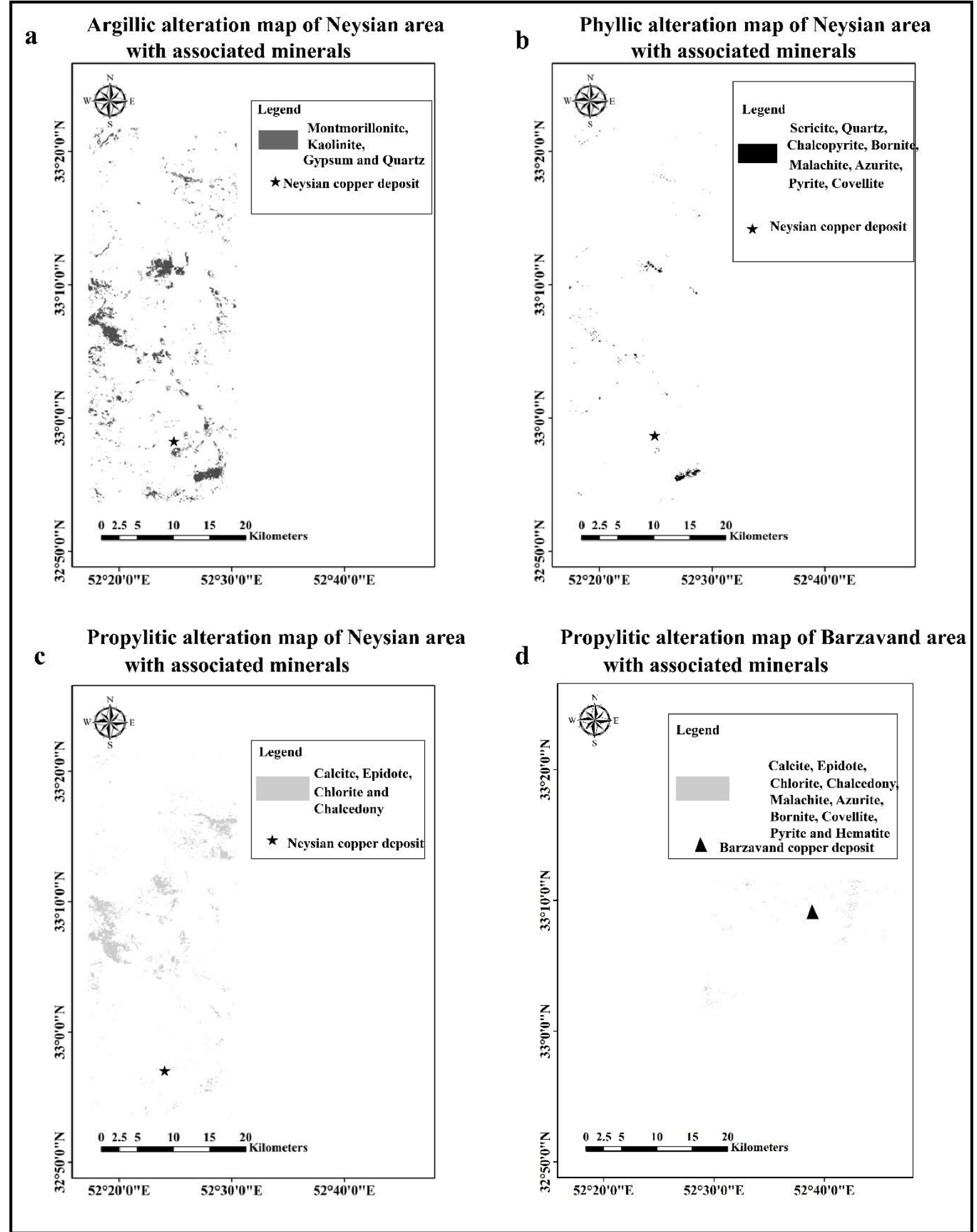

Fig. 13 Alteration map in study area based on field and mineralographical studies. a), b) and c): Argillic, phyllic and propylitic alteration maps with associated minerals from Neysian area, d) propylitic alteration map with associated minerals from Barzavand area. 


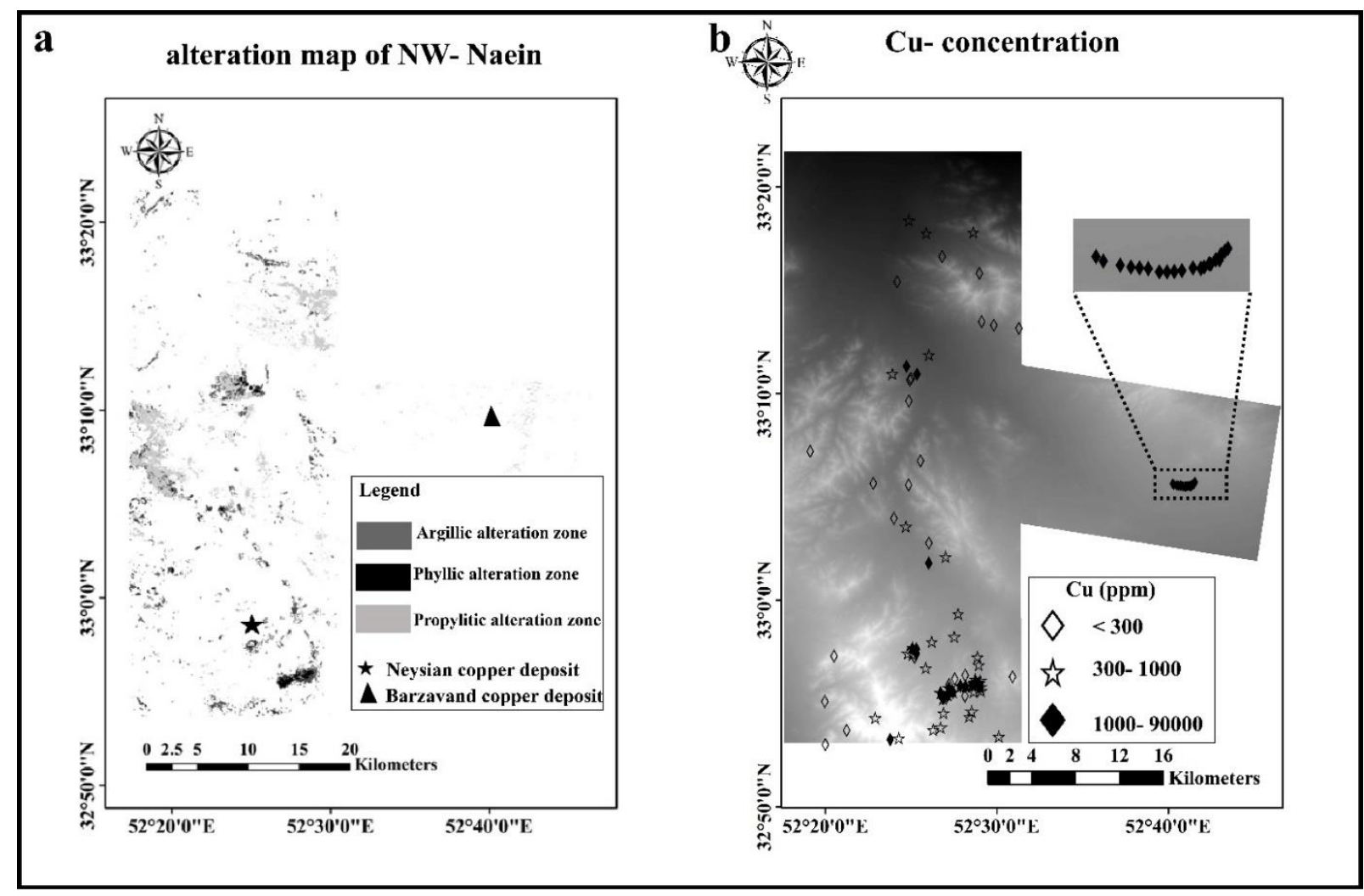

Fig. 14 a) Alteration map of $\mathrm{NW}$ - Naein, b) $\mathrm{Cu}$ - concentration range in study samples.

process include enrichment of $\mathrm{SiO}_{2}, \mathrm{Al}_{2} \mathrm{O}_{3}, \mathrm{Na}_{2} \mathrm{O}$, $\mathrm{K}_{2} \mathrm{O}$, $\mathrm{TiO}_{2}$ and $\mathrm{P}_{2} \mathrm{O}_{5}$, depletion of $\mathrm{MgO}$ and enrichment - depletion of $\mathrm{CaO}, \mathrm{Fe}_{2} \mathrm{O}_{3}, \mathrm{MnO}$, Hf, Sc and $\mathrm{V}$. Increase in $\mathrm{SiO}_{2}$ occur due to formation of chalcedony in basalt fractures and cavities. Aluminum and titanium are immobile elements and can be enriched in alteration products. Increase in $\mathrm{Na}_{2} \mathrm{O}$ occur due to precipitation of $\mathrm{Na}$ - bearing minerals such as zeolite and $\mathrm{Na}$ - rich plagioclase. Increase in $\mathrm{K}_{2} \mathrm{O}$ possibly is related to formation of illite or in the interlayer sites of smectite. Depletion of $\mathrm{Ca}$ due to its high solubility during alteration and its enrichment are related to precipitation of $\mathrm{Ca}$ - bearing minerals such as calcite and chlorite during propylitization or supergene processes. Depletion of $\mathrm{Fe}$ is due to decomposition of pyrite. Also, depletion of $\mathrm{Mg}$ and $\mathrm{Mn}$ is related to the destruction of ferromagnesian minerals during the alteration process.

\subsubsection{TRACE ELEMENTS}

The results show that the trace elements had three different modes of behavior. The first mode belongs to Tl, W, Zn, Ag, As, Be, Bi, Cd, Cs, Cu, Li, Mo, Sb, Se, $\mathrm{Sn}, \mathrm{Ta}, \mathrm{Rb}, \mathrm{Sr}, \mathrm{Ba}, \mathrm{Pb}, \mathrm{Th}, \mathrm{U}, \mathrm{Nb}, \mathrm{Zr}, \mathrm{Y}$ and Te with enrichment in the system during alteration. Second mode is related to elements such as $\mathrm{Ni}, \mathrm{Cr}$ and, Co with depletion and the third mode includes elements such as Hf, Sc, and V with enrichment - depletion during alteration processes. In most samples large lithophile elements (LILE) such as Rb, Sr, Ba, $\mathrm{Pb}$, Th and U, transition elements (TRTE) such as Mo, V, Ag, Co,
$\mathrm{Cu}, \mathrm{W}$ and $\mathrm{Zn}$ and high field strength elements (HFSE) such as $\mathrm{Hf}, \mathrm{Zr}, \mathrm{Nb}$ and $\mathrm{Y}$ are increasing during alteration process. Accompanying silver with copper is one of the most important features of Manto - type copper deposits. In these deposits, Ag concentration has a range of 8 to $32 \mathrm{ppm}$ (Maksaev and Zentilli, 2002).

In Barzavand, Ag concentration varies from 0.6 to $138.5 \mathrm{ppm}$. $\mathrm{Cu}$ concentration in fresh tuff is 524 ppm and has enough potential to supply copper. Brine fluids derived from the related diagenesis of tuff sequence, leached various metals from suitable minerals and redeposit them in the basalt. $\mathrm{Cu}$ ferromagnesian minerals such as biotite, olivine, and pyroxene with volcanic rock fragments are the source of metals. $\mathrm{Cu}$ - bearing sulfides precipitated mainly in veins and basalt cavities where $\mathrm{Cu}$ - bearing brine fluids mixed with syngenetic pyrite and $\mathrm{H}_{2} \mathrm{~S}$ generated by sulfate - reducing bacteria in the host rock. In these conditions pyrite is partially replaced by copper. The propylitization of basalt and trapped seawater can increase the brine fluid $\mathrm{pH}$ and instability of the complex. Positive correlation coefficients between Ag and $\mathrm{As}$ with $\mathrm{Cu}(\mathrm{r}=0.41$ and 0.53 respectively) may be related to substitution of these elements into $\mathrm{Cu}-$ sulfide lattice (Figs. 16a and b).

\subsubsection{RARE EARTH ELEMENTS}

Differentiation, separation, depletion and enrichment of lanthanides during alteration process studied in different ore deposits such as Hizeh - Jan 


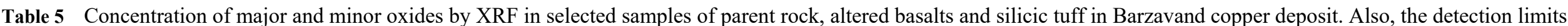
for the elements are listed. DL: Detection limit.

\begin{tabular}{|c|c|c|c|c|c|c|c|c|c|c|c|c|c|c|c|c|c|c|}
\hline Depth & Type & $\begin{array}{l}\text { Element } \\
\text { DL } \\
\text { Samples.N }\end{array}$ & $\begin{array}{c}\mathrm{SiO}_{2} \\
0.05\end{array}$ & $\begin{array}{r}\mathrm{Al}_{2} \mathbf{O}_{3} \\
0.05\end{array}$ & $\begin{array}{l}\mathrm{BaO} \\
0.05\end{array}$ & $\begin{array}{r}\mathrm{CaO} \\
0.05\end{array}$ & $\begin{array}{r}\mathrm{Fe}_{2} \mathrm{O}_{3} \\
0.05\end{array}$ & $\begin{array}{l}\mathrm{K}_{2} \mathrm{O} \\
0.05\end{array}$ & $\begin{array}{r}\text { MgO } \\
0.05\end{array}$ & $\begin{array}{r}\text { MnO } \\
0.05\end{array}$ & $\begin{array}{r}\mathrm{Na}_{2} \mathrm{O} \\
0.05\end{array}$ & $\begin{array}{r}\mathrm{P}_{2} \mathrm{O}_{5} \\
0.05\end{array}$ & $\begin{array}{l}\mathrm{SO}_{3} \\
0.05\end{array}$ & $\begin{array}{c}\mathrm{TiO}_{2} \\
\mathbf{0 . 0 5}\end{array}$ & $\begin{array}{r}\mathrm{Cr}_{2} \mathrm{O}_{3} \\
0.05\end{array}$ & $\begin{array}{l}\text { LOI } \\
0.05\end{array}$ & $\begin{array}{r}\mathrm{Cu} \\
0.05\end{array}$ & Sum \\
\hline 1 & Basalt & B1 & 67.2 & 6.75 & $<$ & 8.7 & 2.83 & 1.21 & 1.52 & 0.12 & 0.69 & 0.1 & 0.1 & 0.28 & $<$ & 9.44 & 1.07 & 100.01 \\
\hline 1 & Basalt & B2 & 49.41 & 13.82 & $<$ & 0.72 & 7.19 & 3.31 & 3.91 & 0.07 & 1.18 & 0.25 & 0.06 & 0.72 & 0.05 & 10.28 & 9.01 & 99.98 \\
\hline 1 & Basalt & B4 & 60.45 & 13.96 & 0.11 & 1.09 & 4.71 & 5.2 & 2.76 & 0.07 & 1.49 & 0.17 & 0.07 & 0.56 & $<$ & 5.71 & 3.66 & 100.01 \\
\hline 1 & Basalt & B6 & 58.22 & 12.96 & 0.08 & 0.6 & 5.21 & 4.57 & 2.72 & 0.05 & 1.05 & 0.24 & 0.06 & 0.63 & $<$ & 6.79 & 6.83 & 100.01 \\
\hline 1 & Basalt & B7 & 70.13 & 13.57 & 0.05 & 0.61 & 4.96 & 3.57 & 0.86 & 0.025 & 1.65 & 0.13 & $<$ & 0.5 & $<$ & 3.88 & 0.09 & 100.00 \\
\hline 12 & Basalt & B8 & 53.42 & 17.46 & 0.07 & 1.12 & 8.79 & 4.3 & 4.46 & 0.1 & 3.23 & 0.5 & 0.07 & 1.08 & $<$ & 5.18 & 0.23 & 100.01 \\
\hline 8 & Basalt & B12 & 46.02 & 17.11 & $<$ & 1.16 & 8.57 & 2.71 & 5.71 & 0.17 & 1.46 & 0.37 & $<$ & 1.13 & $<$ & 7.76 & 7.85 & 100.02 \\
\hline 6 & Basalt & B15 & 56.1 & 13.56 & $<$ & 1.1 & 6.51 & 2.37 & 5.94 & 0.1 & 2.15 & 0.28 & 0.06 & 0.77 & $<$ & 6.63 & 4.42 & 99.99 \\
\hline 4 & Basalt & B16 & 54.98 & 14.56 & 0.1 & 0.6 & 6.46 & 4.67 & 4.32 & 0.1 & 1.81 & 0.2 & $<$ & 0.65 & $<$ & 7.02 & 4.54 & 100.01 \\
\hline 3 & Basalt & B17 & 64.95 & 13.22 & 0.08 & 1.11 & 5.59 & 3.9 & 3.16 & 0.11 & 1.69 & 0.23 & 0.11 & 0.59 & $<$ & 4.32 & 0.95 & 100.01 \\
\hline \multirow[t]{2}{*}{1} & Silicic tuff & B13 & 74.7 & 9.92 & 0.11 & 0.76 & 1.44 & 6.04 & 0.33 & 0.025 & 0.62 & 0.09 & 0.79 & 0.15 & $<$ & 3.19 & 0.07 & 98.99 \\
\hline & Paren rock & P.R & 50 & 4.63 & - & 3.73 & 12 & 0.03 & 32.7 & 0.13 & 0.37 & 0.02 & - & 0.22 & & 1.2 & & 99.93 \\
\hline
\end{tabular}

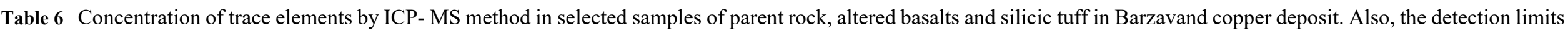
for the elements are listed. DL: Detection limit.

\begin{tabular}{|c|c|c|c|c|c|c|c|c|c|c|c|c|c|c|c|c|c|c|c|}
\hline Depth & Type & $\begin{array}{l}\text { Element } \\
\text { DL } \\
\text { Samples.N }\end{array}$ & $\begin{array}{l}\mathbf{A g} \\
0.1\end{array}$ & $\begin{array}{c}\text { As } \\
0.1\end{array}$ & $\begin{array}{c}\mathbf{B a} \\
\mathbf{1}\end{array}$ & $\begin{array}{l}\mathrm{Be} \\
0.2\end{array}$ & $\begin{array}{c}\mathbf{B i} \\
\mathbf{0 . 1}\end{array}$ & $\begin{array}{l}\text { Cd } \\
0.1\end{array}$ & $\begin{array}{c}\text { Co } \\
1\end{array}$ & $\begin{array}{c}\mathrm{Cr} \\
1\end{array}$ & $\begin{array}{l}\text { Cs } \\
0.5\end{array}$ & $\begin{array}{c}\mathrm{Cu} \\
1\end{array}$ & $\begin{array}{l}\text { Hf } \\
0.5\end{array}$ & $\begin{array}{c}\mathbf{L i} \\
\mathbf{1}\end{array}$ & $\begin{array}{l}\text { Mo } \\
0.1\end{array}$ & $\begin{array}{c}\mathrm{Nb} \\
1\end{array}$ & $\begin{array}{c}\mathbf{N i} \\
\mathbf{1}\end{array}$ & $\begin{array}{c}Y \\
0.5\end{array}$ & $\begin{array}{c}\mathbf{Z r} \\
5\end{array}$ \\
\hline 1 & Basalt & B1 & 0.6 & 7.8 & 201 & 0.7 & 0.5 & 6.2 & 6.9 & 31 & 2.4 & 10152 & 0.25 & 47 & 0.8 & 2.5 & 29 & 7 & 22 \\
\hline 1 & Basalt & B2 & 1.3 & 54.0 & 401 & 1.4 & 1.9 & 4.2 & 20.6 & 127 & 4 & 90100 & 1.57 & 32 & 0.8 & 10.2 & 67 & 16.2 & 68 \\
\hline 1 & Basalt & B4 & 8 & 7.1 & 948 & 1.1 & 0.6 & 1.4 & 12.8 & 29 & 3 & 32610 & 2.41 & 26 & 0.6 & 7.3 & 27 & 13.4 & 87 \\
\hline 1 & Basalt & B6 & 138.5 & 4.8 & 649 & 1.4 & 0.7 & 3.9 & 12.1 & 90 & 4.9 & 68300 & 1.48 & 19 & 0.6 & 6.8 & 45 & 11.9 & 62 \\
\hline 1 & Basalt & B7 & 2.1 & 13.4 & 398 & 1.7 & 0.6 & 13.2 & 4.5 & 20 & 5.5 & 782 & 2.38 & 25 & 1 & 7.1 & 15 & 12.6 & 77 \\
\hline 12 & Basalt & B8 & 1.8 & 12.9 & 564 & 2.1 & 0.4 & 0.9 & 33.6 & 88 & 4.4 & 1930 & 3.92 & 25 & 1 & 15 & 50 & 24.9 & 140 \\
\hline 8 & Basalt & B12 & 0.3 & 11.1 & 262 & 1.4 & 0.4 & 4 & 25 & 143 & 13.1 & 51800 & 2.44 & 25 & 0.7 & 13.8 & 69 & 16.8 & 101 \\
\hline 6 & Basalt & B15 & 5.2 & 8.7 & 368 & 1.2 & 0.4 & 232.8 & 24.9 & 103 & 3.4 & 38108 & 1.71 & 46 & 0.5 & 10.7 & 188 & 14.3 & 68 \\
\hline 4 & Basalt & B16 & 12.7 & 7.3 & 824 & 1.3 & 0.5 & 68.8 & 20.6 & 65 & 3.6 & 40250 & 1.57 & 27 & 0.3 & 7.2 & 87 & 11.6 & 64 \\
\hline 3 & Basalt & B17 & 3.6 & 7.9 & 671 & 1.3 & 0.5 & 2.5 & 16.9 & 58 & 3.5 & 8659 & 1.48 & 33 & 0.6 & 7.9 & 44 & 12.5 & 66 \\
\hline \multirow[t]{2}{*}{1} & Silicic tuff & B13 & 0.6 & 13.6 & 954 & 1.1 & 0.5 & 6272.5 & 14.9 & 15 & 2.9 & 524 & 1.27 & 32 & 0.9 & 10.4 & 2924 & 10.4 & 42 \\
\hline & Parent rock & P.R & 0.1 & 0.1 & 7 & 0.2 & 0.1 & 0.1 & 110 & 2940 & 0.5 & 30 & 0.5 & 1.6 & 0.1 & 0.71 & 1890 & 4.55 & 11.2 \\
\hline
\end{tabular}




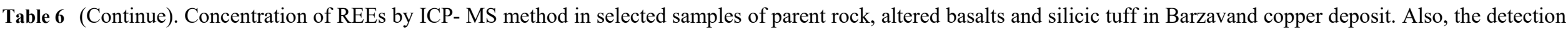
limits for the elements are listed. DL: Detection limit.

\begin{tabular}{|c|c|c|c|c|c|c|c|c|c|c|c|c|c|c|c|c|c|c|c|}
\hline Depth & Type & $\begin{array}{l}\text { Element } \\
\text { DL } \\
\text { Samples.N }\end{array}$ & $\begin{array}{r}\mathbf{P b} \\
1\end{array}$ & $\begin{array}{c}\mathbf{R b} \\
1\end{array}$ & $\begin{array}{l}\text { S } \\
50\end{array}$ & $\begin{array}{l}\mathrm{Sb} \\
0.5\end{array}$ & $\begin{array}{l}\text { Sc } \\
0.5\end{array}$ & $\begin{array}{l}\mathrm{Se} \\
0.5\end{array}$ & $\begin{array}{c}\text { Sn } \\
0.1\end{array}$ & $\begin{array}{r}\mathrm{Sr} \\
1\end{array}$ & $\begin{array}{l}\text { Ta } \\
0.1\end{array}$ & $\begin{array}{l}\text { Te } \\
0.1\end{array}$ & $\begin{array}{l}\text { Th } \\
0.1\end{array}$ & $\begin{array}{l}\text { Tl } \\
0.1\end{array}$ & $\begin{array}{l}\mathrm{U} \\
0.1\end{array}$ & $\begin{array}{l}\mathrm{V} \\
1\end{array}$ & $\begin{array}{r}\mathbf{W} \\
1\end{array}$ & $\begin{array}{c}\mathrm{Zn} \\
1\end{array}$ & $\begin{array}{l}\mathrm{Au} \\
5 \mathrm{ppb}\end{array}$ \\
\hline 1 & Basalt & B1 & 7 & 44 & 77 & 1 & 5.6 & 0.85 & 0.4 & 55.1 & 0.27 & $<0.1$ & $<0.1$ & 0.19 & 3.1 & 76 & 1.1 & 37 & 9 \\
\hline 1 & Basalt & B2 & 11 & 99 & 127 & 1.4 & 17.5 & 2.06 & 0.7 & 107.5 & 0.64 & 0.19 & 0.3 & 0.41 & 19.3 & 290 & 3.7 & 129 & 2110 \\
\hline 1 & Basalt & B4 & 7 & 115 & 101 & 1.3 & 11.8 & 0.83 & 1.1 & 96 & 0.47 & 0.21 & 3.39 & 0.69 & 10.1 & 137 & 2.7 & 74 & 16 \\
\hline 1 & Basalt & B6 & 10 & 128 & 180 & 0.7 & 13.2 & 1.9 & 0.9 & 74.6 & 0.36 & 0.25 & 1.2 & 0.56 & 1.6 & 139 & 2 & 97 & 18 \\
\hline 1 & Basalt & B7 & 32 & 150 & 67 & 0.6 & 8.8 & 1.15 & 1.2 & 85 & 0.38 & 0.11 & 3.95 & 0.46 & 2.2 & 126 & 1 & 18 & 5 \\
\hline 12 & Basalt & B8 & 20 & 159 & 25 & 1.2 & 19.1 & 1.36 & 1.2 & 156.1 & 0.85 & 0.17 & 1.59 & 0.55 & 1.1 & 167 & 5.2 & 147 & 5 \\
\hline 8 & Basalt & B12 & 7 & 105 & 54 & 0.25 & 22.4 & 1.23 & 0.9 & 112 & 0.75 & 0.23 & 0.45 & 0.33 & 5 & 189 & 1.7 & 131 & 5 \\
\hline 6 & Basalt & B15 & 48 & 80 & 215 & 1.3 & 17.8 & 13.38 & 1.5 & 121.2 & 0.64 & 0.27 & 0.31 & 0.39 & 4.2 & 150 & 3.2 & 428 & 5 \\
\hline 4 & Basalt & B16 & 15 & 159 & 117 & 0.8 & 14.2 & 0.96 & 0.8 & 99 & 0.49 & 0.41 & 0.45 & 0.63 & 4.8 & 156 & 2.6 & 188 & 7 \\
\hline 3 & Basalt & B17 & 12 & 153 & 83 & 1.2 & 13.3 & 0.96 & 0.8 & 92.5 & 0.58 & 0.3 & 1.25 & 0.53 & 2.22 & 149 & 3.6 & 68 & 5 \\
\hline \multirow[t]{2}{*}{1} & Silicic tuff & B13 & 711 & 141 & 3347 & 17.1 & 3.2 & 8.52 & 16.4 & 111.9 & 0.73 & 0.05 & 7.4 & 1.96 & 8.1 & 38 & 1.2 & 8255 & 5 \\
\hline & Parent rock & P.R & 1 & 1 & 230 & 0.5 & 17.1 & 0.5 & 0.103 & 21.1 & 0.1 & 0.1 & 0.1 & 0.1 & 0.1 & 82 & 1 & 56 & 7 \\
\hline & & Element & La & $\mathrm{Ce}$ & Pr & & Nd & Sm & Eu & Gd & & & Dy & Ho & $\mathbf{E r}$ & Tm & & $\mathbf{Y b}$ & $\mathbf{L u}$ \\
\hline Depth & Type & $\begin{array}{l}\text { D.L } \\
\text { Samples.N }\end{array}$ & 1 & 0.5 & 0.05 & & 0.5 & 0.02 & 0.1 & 0.05 & & & 0.02 & 0.05 & 0.05 & 0.1 & & 0.05 & 0.1 \\
\hline 1 & Basalt & B1 & 7 & 17 & 1.47 & & 6.8 & 1.24 & 0.58 & 1.23 & & & 1.34 & 0.25 & 0.72 & 0.21 & & 0.7 & $<0.01$ \\
\hline 1 & Basalt & B2 & 8 & 36 & 3.18 & & 13.7 & 3.29 & 1.36 & 3.41 & & & 3.23 & 0.71 & 2.03 & 0.36 & & 1.9 & 0.24 \\
\hline 1 & Basalt & B4 & 4 & 19 & 1.47 & & 6.8 & 1.94 & 0.77 & 1.81 & & & 2.63 & 0.61 & 1.72 & 0.36 & & 1.7 & 0.26 \\
\hline 1 & Basalt & B6 & 3 & 12 & 1.21 & & 6.2 & 1.74 & 0.67 & 1.73 & & & 2.38 & 0.50 & 1.43 & 0.3 & & 1.4 & 0.18 \\
\hline 1 & Basalt & B7 & 8 & 14 & 2.32 & & 10.6 & 2.44 & 0.66 & 2.25 & & & 2.73 & 0.59 & 1.67 & 0.33 & & 1.5 & 0.24 \\
\hline 12 & Basalt & B8 & 20 & 56 & 6.18 & & 26.3 & 5.42 & 1.43 & 5.47 & & & 5.43 & 1.16 & 3.3 & 0.54 & & 2.7 & 0.48 \\
\hline 8 & Basalt & B12 & 7 & 26 & 2.64 & & 12.2 & 2.87 & 1.08 & 3.04 & & & 3.61 & 0.79 & 2.24 & 0.4 & & 2.1 & 0.3 \\
\hline 6 & Basalt & B15 & 4 & 18 & 1.83 & & 9.2 & 2.23 & 0.88 & 2.43 & & & 2.98 & 0.61 & 1.74 & 0.34 & & 1.6 & 0.24 \\
\hline 4 & Basalt & B16 & 2 & 11 & 0.86 & & 5.1 & 1.52 & 0.62 & 1.49 & & & 2.24 & 0.49 & 1.4 & 0.29 & & 1.5 & 0.21 \\
\hline 3 & Basalt & B17 & 3 & 12 & 0.94 & & 4.9 & 1.39 & 0.58 & 1.42 & & & 2 & 0.44 & 1.24 & 0.28 & & 1.5 & 0.16 \\
\hline \multirow[t]{2}{*}{1} & Silicic tuff & B13 & 6 & 18 & 1.97 & & 7.8 & 1.73 & 0.41 & 1.28 & & & 1.87 & 0.44 & 1.24 & 0.3 & & 1.1 & 0.22 \\
\hline & Parent rock & P.R & 0.71 & 1.80 & 0.29 & & 1.38 & 0.47 & 0.17 & 0.6 & & & 0.74 & 0.17 & 0.49 & 0.08 & & 0.5 & 0.1 \\
\hline
\end{tabular}




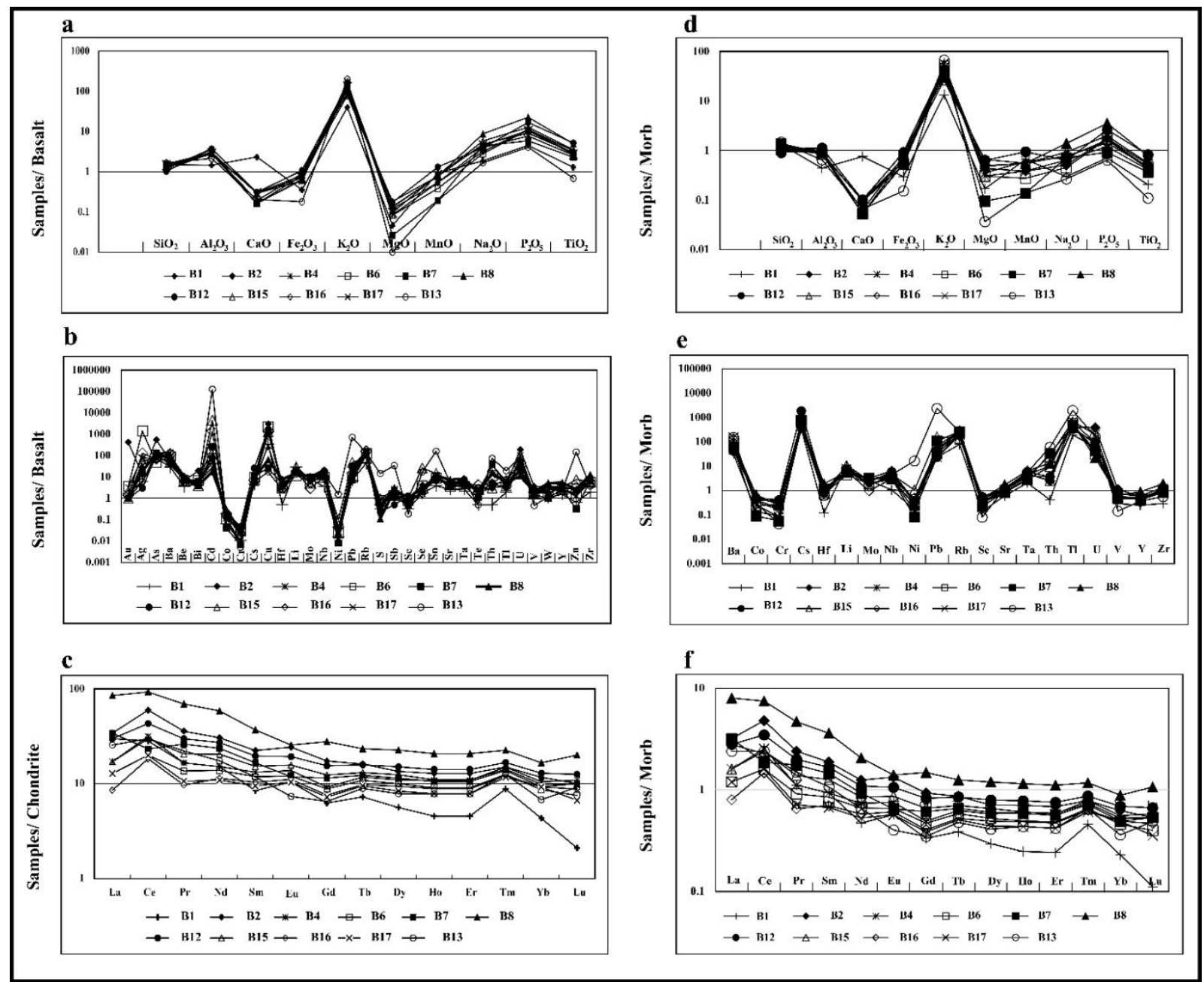

Fig. 15 a) Diagram of normalized major and minor oxides of altered basalt to fresh basalt in Barzavand copper deposit, b) Diagram of normalized trace elements of altered basalt to fresh basalt, c) Diagram of normalized REEs of altered basalt and silicic tuff to chondrite (Sun and McDonough., 1989), d), e) and f) Diagram of normalized major and minor oxides, trace elements and REEs to Mid ocean ridge basalt (Sun and McDonough., 1989).

Table 7 Values of Ce and Eu anomalies by $(\mathrm{La} / \mathrm{Yb})_{\mathrm{N}},(\mathrm{Gd} / \mathrm{Yb})_{\mathrm{N}},(\mathrm{La} / \mathrm{Sm})_{\mathrm{N}},(\mathrm{La} / \mathrm{Lu})_{\mathrm{N}}, \mathrm{La} / \mathrm{Y}, \sum \mathrm{LREE}, \sum \mathrm{HREE}$ and $\sum$ REE in selected samples of Barzavand copper deposit.

\begin{tabular}{llllllllllr}
\hline $\begin{array}{l}\text { Samples. } \\
\text { N }\end{array}$ & $\mathbf{E u} / \mathbf{E u}$ & $\mathbf{C e} / \mathbf{C e}^{*}$ & $(\mathbf{L a} / \mathbf{L u})_{\mathbf{N}}$ & $(\mathbf{L a} / \mathbf{S m})_{\mathbf{N}}$ & $(\mathbf{L a} / \mathbf{Y b})_{\mathbf{N}}$ & $(\mathbf{G d} / \mathbf{Y b})_{\mathbf{N}}$ & $\mathbf{L a} / \mathbf{Y}$ & $\mathbf{R E E} \sum$ & $\mathbf{L R E E} \sum$ & HREE $\sum$ \\
\hline B1 & 1.43 & 1.13 & 14.3 & 3.53 & 6.94 & 1.45 & 1 & 38.85 & 4.76 & 34.09 \\
$\mathbf{B 2}$ & 1.23 & 1.82 & 3.4 & 1.52 & 2.92 & 1.48 & 0.49 & 77.99 & 12.46 & 65.53 \\
B4 & 1.25 & 1.92 & 1.57 & 1.29 & 1.63 & 0.88 & 0.3 & 43.49 & 9.51 & 33.98 \\
B6 & 1.18 & 1.52 & 1.7 & 1.08 & 1.49 & 1.02 & 0.25 & 33.13 & 8.31 & 24.82 \\
B7 & 0.86 & 0.76 & 3.4 & 2.05 & 3.7 & 1.24 & 0.63 & 47.77 & 9.75 & 38.02 \\
B8 & 0.8 & 1.22 & 4.26 & 2.31 & 5.14 & 1.68 & 0.8 & 135.25 & 19.92 & 115.33 \\
B12 & 1.11 & 1.49 & 2.38 & 1.53 & 2.31 & 1.2 & 0.42 & 64.84 & 13.05 & 51.79 \\
B15 & 1.15 & 1.64 & 1.7 & 1.12 & 1.73 & 1.26 & 0.28 & 46.55 & 10.41 & 36.14 \\
B16 & 1.25 & 1.93 & 0.97 & 0.82 & 0.92 & 0.82 & 0.17 & 29.07 & 7.97 & 21.10 \\
B17 & 1.26 & 1.64 & 1.91 & 1.35 & 1.39 & 0.78 & 0.24 & 30.19 & 7.38 & 22.81 \\
B13 & 0.84 & 1.31 & 2.79 & 2.17 & 3.78 & 0.96 & 0.58 & 42.68 & 6.77 & 35.91 \\
\hline
\end{tabular}




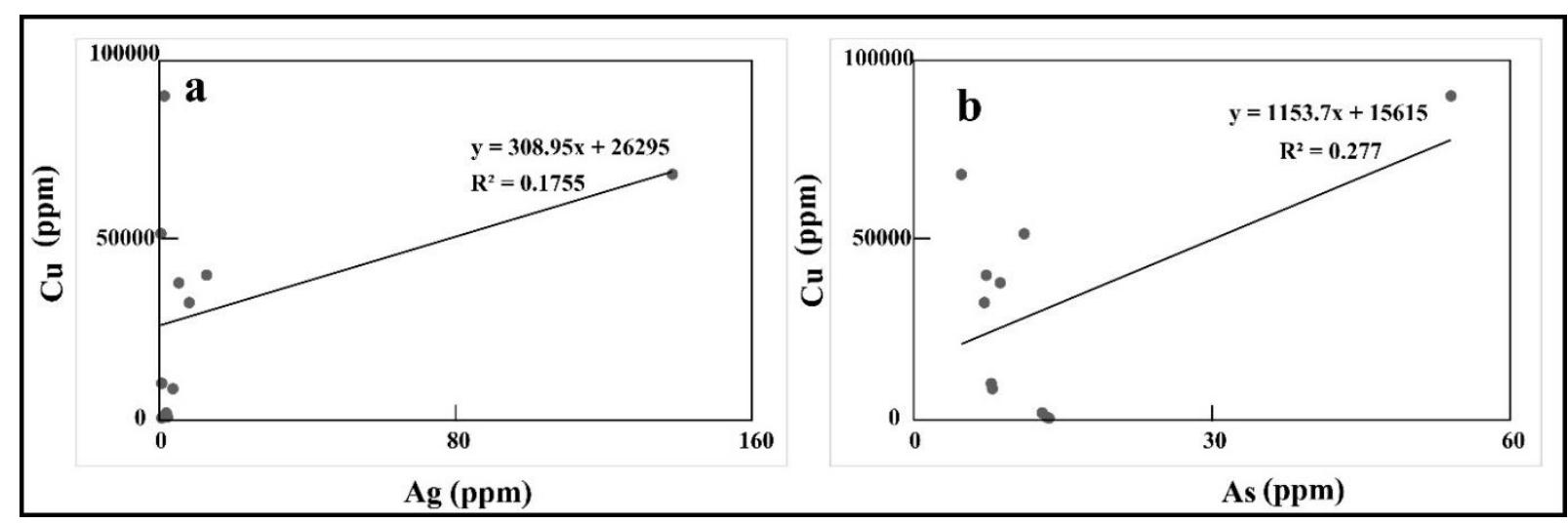

Fig. 16 Correlation coefficient between a) $\mathrm{Ag}-\mathrm{Cu}$ and b) $\mathrm{As}-\mathrm{Cu}$ in Barzavand copper deposit.

kaolin deposit (Abedini and Rezaei Azizi, 2019); Argillic and propylitic alteration zones of epithermal $\mathrm{Cu}-\mathrm{Pb}-\mathrm{Fe}$ deposits of Khan Kandi district (Abedini et al., 2020) and chromite in the Jijal complex Ophiolite (Ullah et al., 2020a).

Acidic and alkaline conditions cause depletion and enrichment of REEs in the alteration systems (Patino et al., 2003). $\sum$ REE in Barzavand copper deposit increased that may be associated with high $\mathrm{pH}$. In this study, the Eu and $\mathrm{Ce}$ anomalies are calculated in the following equations (Table 7):

$\mathrm{Eu} / \mathrm{Eu}^{*}=\left(\mathrm{Eu}_{\mathrm{N}}\right) / \sqrt{ } \mathrm{Sm}_{\mathrm{N}} \times \mathrm{Gd}_{\mathrm{N}}$

(Taylor and McLennan, 1985)

$\mathrm{Ce} / \mathrm{Ce}^{*}=\left(3 \mathrm{Ce}_{\mathrm{N}}\right) /\left(2 \mathrm{La}_{\mathrm{N}}+\mathrm{Nd}_{\mathrm{N}}\right)$

(Taylor and McLennan, 1985)

In the equations, $\mathrm{N}$ denotes the normalization of the REE to chondrite (Taylor and Mclennan, 1985). Eu and $\mathrm{Ce}$ anomalies vary from 0.80 to 1.43 and 0.76 to 1.93 in altered samples. The ionic radius of $\mathrm{Eu}^{2+}$ is about $1.25 \mathrm{~A}^{\circ}$ and is near to that of $\mathrm{Ca}^{2+}\left(1 \mathrm{~A}^{\circ}\right)$ and $\mathrm{Sr}^{2+}\left(1.13 \mathrm{~A}^{\circ}\right)$, so Eu can substitute for $\mathrm{Ca}$ and $\mathrm{Sr}$ in plagioclase crystal structure (Laufer et al., 1984). It seems that during the destruction of plagioclase, $\mathrm{Ca}$ and $\mathrm{Sr}$ are released and transported by solution and lead to negative Eu anomaly in the primary steps of the alteration process. The occurrence of negative Eu anomaly in Hizeh - Jan kaolin deposit (Abedini and Rezaei Azizi, 2019); Argillic alteration zone in Jizvan district (Abedini et al., 2018) and argillic and propylitic alteration zones of epithermal $\mathrm{Cu}-\mathrm{Pb}-\mathrm{Fe}$ deposits of Khan Kandi district (Abedini et al., 2020) is related to the destruction of the feldspars of the parent rocks by hydrothermal fluids. Also Positive Eu anomaly may be related to precipitation of $\mathrm{Ca}$ and $\mathrm{Sr}$ minerals during alteration system.

The amount of $\mathrm{Ce} / \mathrm{Ce}^{*}$ anomalies in altered samples varying from 0.76 to 1.93 . The positive $\mathrm{Ce}$ anomaly during alteration is due to conversion of $\mathrm{Ce}^{3+}$ into insoluble $\mathrm{Ce}^{4+}$ in oxidizing conditions. Amount of $(\mathrm{La} / \mathrm{Lu})_{\mathrm{N}},(\mathrm{La} / \mathrm{Sm})_{\mathrm{N}},(\mathrm{La} / \mathrm{Yb})_{\mathrm{N}}$ and $(\mathrm{Gd} / \mathrm{Yb})_{\mathrm{N}}$ ratio varying between 0.97 to $14.30,0.82$ to $3.53,0.92$ to 6.94 and 0.78 to 1.68 respectively (Table 7 ). The values of Pearson correlation coefficients (Rollinson, $1993)$ between $\mathrm{Ce} / \mathrm{Ce}^{*}, \mathrm{Eu} / \mathrm{Eu}^{*},(\mathrm{La} / \mathrm{Yb})_{\mathrm{N}},(\mathrm{Gd} / \mathrm{Yb})_{\mathrm{N}}$ $(\mathrm{La} / \mathrm{Lu})_{\mathrm{N}}$ and $(\mathrm{La} / \mathrm{Sm})_{\mathrm{N}}, \Sigma \mathrm{LREE}, \Sigma \mathrm{HREE}$ and $\Sigma$ REE with some major and minor oxides and trace elements in Barzavand copper deposit listed in Table 8. The positive correlation between $\mathrm{Ce} / \mathrm{Ce}^{*}$ with $\mathrm{Cu}(\mathrm{r}=0.60)$ indicate the role of $\mathrm{Cu}$ - bearing minerals in distribution of Ce anomaly (Table 8).

There is a positive correlation between REEs with $\mathrm{Zr}$ and $\mathrm{P}$ ( $\mathrm{r}=0.78$ and 0.80 respectively). In this regard, zircon and secondary phosphate minerals are host for REEs in Barzavand copper deposit (Table 8). Positive correlation coefficient between $\mathrm{Y}$ and REEs $(r=0.91)$ indicate their similar geochemical roles during evolution of this deposit. Positive correlation between $(\mathrm{La} / \mathrm{Lu})_{\mathrm{N}},(\mathrm{La} / \mathrm{Yb})_{\mathrm{N}},(\mathrm{La} / \mathrm{Sm})_{\mathrm{N}}$ and $\mathrm{La} / \mathrm{Y}$ and $\mathrm{CaO}(\mathrm{r}=0.70$ to 0.96 ) (Table 8) indicate that propylitization of host rock basalt and increase in $\mathrm{pH}$ of fluid responsible for mineralization play important role in differentiation of lanthanides in the study area. Also, $\sum \mathrm{REE}, \mathrm{Al}$ and HFSE are mobilized under high temperature of fluid responsible for alteration, but at lower temperatures the concentration of these elements increase (Salvi and Jones, 1996). In the Barzavand copper system, $\sum \mathrm{REE}, \mathrm{Al}$ and HFSE have positive anomalies. It seems that they are immobile under low - temperature conditions. Regards to La/Y less than 1 in most samples, it seems copper transported by chloride ligands and precipitated by decrease in fluid redox potential and fluid temperature.

\subsubsection{CLASSIFICATION OF VOLCANIC ROCKS AND THEIR TECTONIC SETTING}

Using mobile elements to determine tectonic setting carried out in different deposits such as chromite occurrences of Dargai Complex (Ullah et al., 2020b). However, it was difficult to find fresh parent rocks in Barzavand Copper deposit because of high intensity of alteration, so we used diagrams based on immobile elements to determine parent rocks composition and their tectonic setting.

Plotting data for altered samples that are host for $\mathrm{Cu}-$ mineralization in bivariate diagrams $\mathrm{Zr} / \mathrm{TiO}_{2}-\mathrm{Nb} / \mathrm{Y}$ (Winchester and Floyd,1977), most of 
Table 8 The values of Pearson correlation coefficients (Rollinson, 1993) between $(\mathrm{Ce} / \mathrm{Ce})^{*},(\mathrm{Eu} / \mathrm{Eu})^{*},(\mathrm{La} / \mathrm{Yb})_{\mathrm{N}}$, $(\mathrm{Gd} / \mathrm{Yb})_{\mathrm{N}},(\mathrm{La} / \mathrm{Lu})_{\mathrm{N}},(\mathrm{La} / \mathrm{Sm})_{\mathrm{N}}, \mathrm{La} / \mathrm{Y}, \Sigma \mathrm{LREE}, \Sigma \mathrm{HREE}$ and $\Sigma \mathrm{REE}$ with some of major and minor oxides and trace elements in Barzavand copper deposit.

\begin{tabular}{|c|c|c|c|c|c|c|c|c|c|c|}
\hline & $(\mathrm{Eu} / \mathrm{Eu})^{*}$ & $(\mathrm{Ce} / \mathrm{Ce} *)$ & $(\mathbf{L a} / \mathbf{L u})_{\mathbf{N}}$ & $(\mathbf{L a} / \mathbf{S m})_{\mathbf{N}}$ & $(\mathbf{L a} / \mathbf{Y b})_{\mathbf{N}}$ & $(G d / Y b)_{N}$ & $\mathbf{L a} / \mathbf{Y}$ & REE & LREE & HREE \\
\hline $\mathbf{S i}$ & 0.09 & -0.51 & 0.38 & 0.40 & 0.28 & -0.21 & 0.26 & -0.46 & -0.59 & -0.44 \\
\hline Al & -0.67 & 0.20 & -0.75 & -0.54 & -0.43 & 0.00 & -0.37 & 0.54 & 0.79 & 0.50 \\
\hline $\mathbf{C a}$ & 0.51 & -0.34 & 0.96 & 0.84 & 0.76 & 0.32 & 0.70 & -0.14 & -0.44 & -0.09 \\
\hline $\mathbf{F e}$ & -0.55 & 0.19 & -0.51 & -0.36 & -0.22 & 0.29 & -0.17 & 0.69 & 0.85 & 0.65 \\
\hline $\mathbf{K}$ & -0.27 & 0.40 & -0.70 & -0.62 & -0.58 & -0.49 & -0.55 & 0.04 & 0.23 & 0.02 \\
\hline Mg & -0.08 & 0.51 & -0.45 & -0.47 & -0.39 & 0.07 & -0.39 & 0.32 & 0.49 & 0.29 \\
\hline Mn & 0.27 & 0.19 & 0.20 & 0.14 & 0.09 & 0.06 & 0.07 & 0.12 & 0.10 & 0.12 \\
\hline $\mathbf{N a}$ & -0.73 & -0.07 & -0.36 & -0.14 & -0.01 & 0.26 & 0.01 & 0.67 & 0.77 & 0.65 \\
\hline $\mathbf{P}$ & -0.57 & 0.05 & -0.31 & -0.13 & 0.00 & 0.42 & 0.02 & 0.80 & 0.89 & 0.78 \\
\hline $\mathbf{T i}$ & -0.55 & 0.13 & -0.46 & -0.30 & -0.18 & 0.29 & -0.14 & 0.67 & 0.84 & 0.64 \\
\hline Ag & 0.07 & 0.07 & -0.21 & -0.31 & -0.30 & -0.25 & -0.32 & -0.27 & -0.20 & -0.28 \\
\hline As & -0.01 & 0.17 & 0.00 & 0.00 & 0.10 & 0.45 & 0.14 & 0.37 & 0.30 & 0.38 \\
\hline Be & -0.92 & -0.30 & -0.44 & -0.15 & -0.01 & 0.33 & 0.05 & 0.71 & 0.82 & 0.69 \\
\hline Co & -0.34 & 0.34 & -0.35 & -0.27 & -0.14 & 0.31 & -0.13 & 0.67 & 0.77 & 0.65 \\
\hline $\mathrm{Cr}$ & -0.09 & 0.33 & -0.32 & -0.35 & -0.25 & 0.28 & -0.23 & 0.38 & 0.50 & 0.36 \\
\hline Cs & -0.30 & -0.15 & -0.23 & -0.12 & -0.13 & 0.06 & -0.07 & 0.18 & 0.33 & 0.15 \\
\hline $\mathrm{Cu}$ & 0.33 & 0.60 & -0.33 & -0.50 & -0.44 & -0.05 & -0.44 & -0.09 & 0.00 & -0.10 \\
\hline Hf & -0.86 & -0.14 & -0.46 & -0.15 & -0.04 & 0.27 & 0.03 & 0.75 & 0.89 & 0.72 \\
\hline $\mathbf{N b}$ & -0.64 & 0.08 & -0.47 & -0.26 & -0.14 & 0.37 & -0.09 & 0.75 & 0.91 & 0.72 \\
\hline $\mathbf{N i}$ & 0.06 & 0.38 & -0.31 & -0.43 & -0.35 & 0.04 & -0.39 & -0.03 & 0.11 & -0.05 \\
\hline $\mathbf{Y}$ & -0.73 & -0.02 & -0.35 & -0.10 & 0.05 & 0.49 & 0.10 & 0.91 & 0.99 & 0.89 \\
\hline $\mathbf{Z r}$ & -0.79 & -0.05 & -0.46 & -0.18 & -0.07 & 0.27 & 0.00 & 0.78 & 0.92 & 0.75 \\
\hline $\mathbf{R b}$ & -0.57 & 0.02 & -0.64 & -0.46 & -0.41 & -0.35 & -0.37 & 0.17 & 0.34 & 0.14 \\
\hline $\mathbf{S r}$ & -0.64 & 0.15 & -0.44 & -0.25 & -0.10 & 0.37 & -0.06 & 0.79 & 0.91 & 0.76 \\
\hline V & -0.12 & 0.44 & -0.42 & -0.39 & -0.29 & 0.22 & -0.24 & 0.42 & 0.49 & 0.40 \\
\hline
\end{tabular}

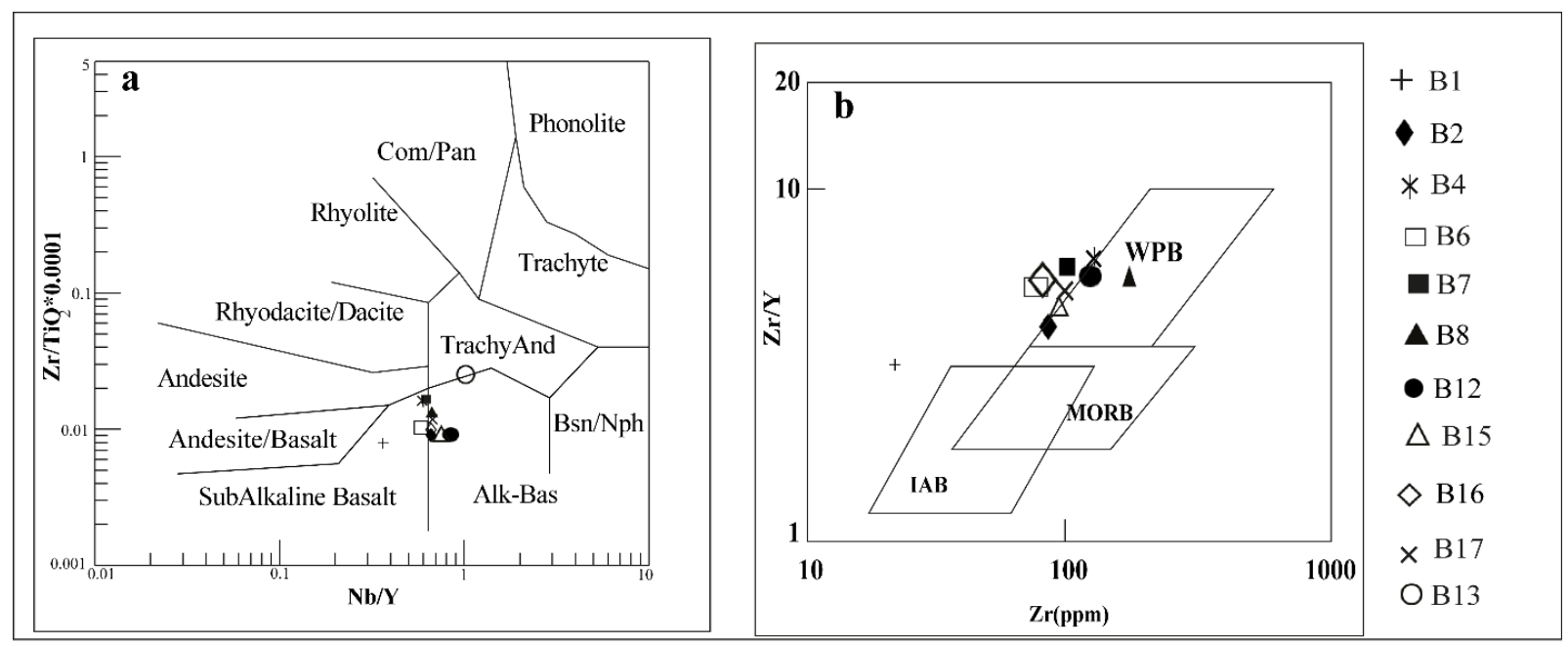

Fig 17 a) Volcanic rocks plot in bivariate diagram $\mathrm{Nb} / \mathrm{Y}-\mathrm{Zr} / \mathrm{TiO}_{2}$ (Winchester and Floyd, 1977), b) Volcanic rocks plot in bivariate diagram $\mathrm{Zr}-\mathrm{Zr} / \mathrm{Y}$ (Pearce and Norry, 1979) (WPB: Within Plate Basalt, MORB: Mid- Oceanic Ridge Basalts and IAT: Island Arc Tholeities).

volcanic rocks plot within alkali basalts field (Fig. 17a) and a few samples plot between alkali and subalkaline basalts. Also by using bivariate diagram $\mathrm{Zr}-\mathrm{Zr} / \mathrm{Y}$ (Pearce and Norry,1979), some samples plot in within plate basalts (WPB) and some samples plot near this field (Fig. 17b). Alkali basalts and within plate basalts, indicate extensional tectonic setting (Rajabi and Torabi, 2013).

\subsubsection{GEOCHEMICAL STUDY IN NEYSIAN ALTERATION SYSTEM}

The results of geochemical analyses are listed in Tables 9 to 11. The amount of Eu and Ce anomalies with $(\mathrm{La} / \mathrm{Lu})_{\mathrm{N}},(\mathrm{La} / \mathrm{Sm})_{\mathrm{N}},(\mathrm{La} / \mathrm{Yb})_{\mathrm{N}}$ and $(\mathrm{Gd} / \mathrm{Yb})_{\mathrm{N}}$ ratios are listed in Table 12. Common bivariate plot of major elements $\left(\mathrm{Na}_{2} \mathrm{O}+\mathrm{K}_{2} \mathrm{O}-\mathrm{SiO}_{2}\right)(\mathrm{Cox}$ et al., 1979) is used to determine the composition of the parent rock. With the use of TAS diagram the samples plot in 
Table 9 Concentration of major and minor oxides of fresh volcanic rocks by XRF in Neysian copper deposit.

\begin{tabular}{|c|c|c|c|c|c|c|c|c|c|c|c|c|}
\hline oxides & $\begin{array}{c}\text { Detection } \\
\text { limite }\end{array}$ & 1 & 2 & 3 & 4 & 5 & 6 & 7 & 8 & 9 & 10 & 11 \\
\hline Symbole & & 0 & $\triangle$ & + & $x$ & 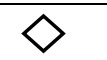 & $\nabla$ & 凶 & * & $\diamond$ & $\bigoplus$ & $\phi$ \\
\hline $\mathrm{SiO}_{2}$ & 0.01 & 80.90 & 76.12 & 77.12 & 57.95 & 54.05 & 55.45 & 57.20 & 63.35 & 61.42 & 58.35 & 83.95 \\
\hline $\mathrm{TiO}_{2}$ & 0.01 & 0.16 & 0.25 & 0.25 & 0.23 & 1.12 & 0.75 & 0.72 & 0.72 & 0.70 & 0.75 & 0.11 \\
\hline $\mathrm{Al}_{2} \mathrm{O}_{3}$ & 0.04 & 6.20 & 8.90 & 8.79 & 17.05 & 17.08 & 16.05 & 13.55 & 13.55 & 16.95 & 15.12 & 6.12 \\
\hline $\mathrm{Fe}_{2} \mathrm{O}_{3}$ & 0.01 & 1.68 & 1.81 & 1.78 & 1.81 & 2.45 & 2.35 & 2.29 & 2.29 & 2.29 & 2.39 & 1.65 \\
\hline $\mathrm{FeO}$ & 0.01 & 0.30 & 1.03 & 1.05 & 5.08 & 6.23 & 5.75 & 3.11 & 3.11 & 3.11 & 5.95 & 0.05 \\
\hline MnO & 0.01 & 0.02 & 0.05 & 0.05 & 0.17 & 0.14 & 0.25 & 0.25 & 0.25 & 0.25 & 0.18 & 0.08 \\
\hline MgO & 0.01 & 0.14 & 0.49 & 0.39 & 7.95 & 6.25 & 6.80 & 2.18 & 2.18 & 2.18 & 3.85 & 0.41 \\
\hline $\mathrm{CaO}$ & 0.01 & 0.48 & 2.06 & 2.43 & 7.90 & 8.44 & 9.35 & 2.95 & 2.95 & 2.95 & 8.71 & 0.45 \\
\hline $\mathrm{Na}_{2} \mathrm{O}$ & 0.01 & 4.42 & 3.63 & 4.81 & 2.33 & 2.65 & 1.75 & 5.58 & 5.57 & 5.58 & 2.58 & 4.22 \\
\hline $\mathrm{K}_{2} \mathrm{O}$ & 0.01 & 4.68 & 3.02 & 3.33 & 0.15 & 1.75 & 0.88 & 5.85 & 5.85 & 5.85 & 0.17 & 1.63 \\
\hline $\mathrm{P}_{2} \mathrm{O}_{5}$ & 0.01 & 0.06 & 0.11 & 0.10 & 0.25 & 0.57 & 0.25 & 0.30 & 0.30 & 0.30 & 0.15 & 0.05 \\
\hline Sum & & 99.07 & 97.47 & 100.1 & 100.87 & 100.73 & 99.63 & 93.98 & 100.12 & 101.58 & 98.20 & 98.72 \\
\hline
\end{tabular}

Table 10 Concentration of major, minor and trace elements with LOI in Neysian copper deposit. Also, the detection limits for the elements are listed. DL: Detection limit. K: samples of argillic zone, ph: samples of phyllic zone with $\mathrm{Cu}$ - mineralization.

\begin{tabular}{|c|c|c|c|c|c|c|c|c|c|}
\hline Sample No & $\begin{array}{c}\text { Detection } \\
\text { limit }\end{array}$ & K-1 & K2 & K-3 & K-4 & K-5 & K-10 & Ph-1 & 5 \\
\hline $\mathrm{SiO}_{2}$ wt.\%) & 0.01 & 65.16 & 65.95 & 67.12 & 68.99 & 68.85 & 44.70 & 63.83 & 54.05 \\
\hline $\mathrm{TiO}_{2}$ & 0.01 & 0.43 & 0.33 & 0.28 & 0.55 & 0.36 & 0.28 & 0.46 & 1.12 \\
\hline $\mathrm{Al}_{2} \mathrm{O}_{3}$ & 0.04 & 16.91 & 17.14 & 15.88 & 15.54 & 13.88 & 11.47 & 12.47 & 17.08 \\
\hline $\mathrm{Fe}_{2} \mathrm{O}_{3}$ & 0.01 & 1.45 & 1.32 & 1.15 & 1.38 & 1.84 & 2.23 & 4.97 & 2.45 \\
\hline $\mathrm{FeO}$ & 0.01 & 2.18 & 2.22 & 1.98 & 2.02 & 2.08 & & - & 6.23 \\
\hline MnO & 0.01 & 0.07 & 0.04 & 0.09 & 0.07 & 0.03 & 0.11 & 0.46 & 0.14 \\
\hline MgO & 0.01 & 2.28 & 1.75 & 1.58 & 1.55 & 1.95 & 0.26 & 0.84 & 6.25 \\
\hline $\mathrm{CaO}$ & 0.01 & 4.55 & 4.85 & 3.85 & 3.25 & 4.25 & 20.52 & 1.61 & 8.44 \\
\hline $\mathrm{Na}_{2} \mathrm{O}$ & 0.01 & 3.82 & 3.67 & 4.95 & 3.33 & 3.68 & 1.037 & 0.911 & 2.65 \\
\hline $\mathbf{K}_{2} \mathbf{O}$ & 0.01 & 1.98 & 2.10 & 2.18 & 1.85 & 2.19 & 0.06 & 6.91 & 1.75 \\
\hline $\mathrm{P}_{2} \mathrm{O}_{5}$ & 0.01 & 0.22 & 0.48 & 0.45 & 0.50 & 0.15 & 0.09 & 0.25 & 0.57 \\
\hline LOI & 0.05 & 0.5 & 0.20 & 0.20 & 1 & 0.5 & 19 & 1.5 & - \\
\hline Sum & - & 99.55 & 100.05 & 99.71 & 100.03 & 99.76 & 99.76 & 99.54 & 100.73 \\
\hline $\mathrm{Cr}$ (ppm) & 0.002 & 10.00 & 12.00 & 11.00 & 9.00 & 10.00 & 6 & 12 & 2680 \\
\hline $\mathrm{Ni}$ & 0.1 & 13.00 & 14.00 & 9.00 & 12.00 & 15.00 & 4 & 1130 & 11100 \\
\hline $\mathbf{R b}$ & 0.1 & 73.00 & 54.00 & 70.00 & 105.00 & 98.00 & 1 & 288 & 2.4 \\
\hline Cs & 0.1 & 1.50 & 1.30 & 1.20 & 1.40 & 2.10 & 1.3 & 6.2 & 0.19 \\
\hline Ba & 1 & 650.00 & 605.00 & 633.00 & 750.00 & 695.00 & 45 & 1009 & 2.40 \\
\hline $\mathrm{Sr}$ & 0.5 & 312.00 & 335.00 & 320.00 & 199.00 & 270.00 & 242 & 140 & 8 \\
\hline Nb & 0.1 & 6.35 & 6.95 & 7.98 & 8.12 & 9.70 & 1.8 & 7.8 & 0.25 \\
\hline Hf & 0.1 & 3.00 & 2.50 & 4.00 & 1.80 & 2.65 & 0.5 & 0.5 & 0.1 \\
\hline $\mathbf{Z r}$ & 0.1 & 45.00 & 55.00 & 88.00 & 65.00 & 77.00 & 13 & 13 & 3.96 \\
\hline $\mathbf{Y}$ & 0.1 & 11.00 & 13.22 & 14.28 & 9.50 & 10.45 & 16.3 & 20.3 & 1.6 \\
\hline Th & 0.1 & 7.45 & 6.75 & 9.27 & 12.10 & 10.00 & 0.87 & 4.34 & 0.1 \\
\hline $\mathbf{U}$ & 0.1 & 1.80 & 1.40 & 2.90 & 2.30 & 3.00 & 0.3 & 1.48 & 0.1 \\
\hline $\mathrm{Cu}$ & 1 & 90 & 85 & 87 & 78 & 75 & 90 & 53300 & 126 \\
\hline
\end{tabular}

the basaltic andesite, andesite, trachyte, trachydacite and rhyolite fields (Fig. 18). For determining the magmatic series, the AFM diagram are useful (Irvin and Baraga, 1971). Our samples plot in the calk-alkaline field and some of them are near the calc-alkaline-tholeiitic boundary (Fig. 19).

\subsubsection{BEHAVIOUR OF ELEMENTS IN NEYSIAN COPPER DEPOSIT DURING ALTERATION}

To display the behavior of elements during alteration processes, the normalized diagrams of major, minor and trace elements to parent rock (Figs. 20a and b) and rare earth elements to chondrite (Fig. 20c) were used (Taylor and McLennan, 1985). The results show that the major, minor and REEs at Neysian was accompanied by enrichment of Cs, Ba, $\mathrm{Sr}, \mathrm{Nb}, \mathrm{Hf}, \mathrm{Zr}, \mathrm{Y}, \mathrm{Th}, \mathrm{Al}$ and $\mathrm{U}$, depletion of $\mathrm{Mg}, \mathrm{Cr}$, $\mathrm{Ni}$ and REEs and fixation- depletion of $\mathrm{Rb}, \mathrm{Si}, \mathrm{Ca}, \mathrm{Ti}$, $\mathrm{Na}, \mathrm{P}, \mathrm{Fe}, \mathrm{K}, \mathrm{Mn}, \mathrm{Al}$ and $\mathrm{Cu}$. The chondrite normalized REE patterns of the argillic and silicic samples are almost parallel. It seems the silicic samples form during the decomposition of 
Table 11 Concentration of REEs in Neysian copper deposit. Also, the detection limits for the elements are listed.

DL: Detection limit. K: samples of argillic zone, ph: sample of phyllic zone with $\mathrm{Cu}$ - mineralization.

\begin{tabular}{lcrrrrrrrrrrrr}
$\begin{array}{l}\text { Sample } \\
\text { No }\end{array}$ & $\begin{array}{c}\text { Detection } \\
\text { limit }\end{array}$ & $\mathbf{K - 1}$ & $\mathbf{K 2}$ & $\mathbf{K - 3}$ & $\mathbf{K - 4}$ & $\mathbf{K - 5}$ & $\mathbf{K - 6}$ & $\mathbf{K - 7}$ & $\mathbf{K - 8}$ & $\mathbf{K - 9}$ & K-10 & Ph-1 & Si \\
\hline La & 0.1 & 15.00 & 13.00 & 14.00 & 22.00 & 18.00 & 41.61 & 42.90 & 27.80 & 23.15 & 16 & 12 & 13.76 \\
(ppm) & & & & & & & & & & & & & \\
Ce & 0.1 & 42.00 & 35.00 & 25.00 & 26.00 & 38.00 & 72.87 & 71.70 & 48.23 & 42.94 & 23 & 20 & 22.11 \\
Pr & 0.02 & 5.45 & 3.39 & 6.20 & 4.12 & 4.25 & 7.99 & 7.67 & 5.29 & 4.87 & 2.09 & 2.67 & 3.21 \\
Nd & 0.3 & 13.30 & 8.50 & 10.15 & 12.00 & 16.00 & 28.77 & 26.21 & 19.05 & 18.38 & 12.6 & 12 & 7.20 \\
Sm & 0.05 & 3.65 & 3.15 & 2.87 & 2.16 & 3.14 & 4.81 & 3.70 & 3.39 & 3.47 & 2.54 & 3.06 & 1.13 \\
Eu & 0.02 & 0.91 & 0.88 & 0.95 & 1.10 & 0.94 & 1.44 & 0.86 & 0.99 & 1.04 & 0.7 & 0.63 & 0.20 \\
Gd & 0.05 & 2.17 & 1.44 & 2.18 & 2.45 & 1.35 & 3.49 & 1.80 & 2.64 & 3.52 & 2.72 & 3.19 & 0.70 \\
Tb & 0.01 & 0.44 & 0.35 & 0.32 & 0.31 & 0.40 & 2.48 & 0.19 & 0.39 & 0.69 & 0.42 & 0.57 & 0.31 \\
Dy & 0.05 & 2.11 & 2.81 & 1.98 & 1.80 & 2.14 & 0.48 & 0.80 & 2.16 & 5.30 & 3.16 & 0.42 & 0.94 \\
Ho & 0.05 & 0.3 & 0.50 & 0.60 & 0.20 & 0.40 & 0.44 & 0.14 & 0.42 & 1.19 & 0.63 & 0.62 & 0.22 \\
Er & 0.03 & 0.55 & 0.42 & 1.15 & 0.98 & 1.66 & 1.10 & 0.45 & 1.10 & 3.35 & 1.8 & 2.65 & 0.49 \\
Tm & 0.01 & 0.23 & 0.20 & 0.18 & 0.14 & 0.33 & 0.15 & 0.08 & 0.16 & 0.46 & 0.26 & 0.37 & 0.06 \\
Yb & 0.05 & 1.50 & 1.20 & 1.80 & 1.40 & 1.80 & 0.89 & 0.62 & 1.02 & 2.72 & 1.7 & 3 & 0.45 \\
Lu & 0.05 & 0.15 & 0.12 & 0.23 & 0.14 & 0.19 & 0.14 & 0.12 & 0.16 & 0.88 & 0.26 & 0.33 & 0.06 \\
\hline
\end{tabular}

Table 12 Concentration of $(\mathrm{La} / \mathrm{Sm})_{\mathrm{N}},(\mathrm{La} / \mathrm{Lu})_{\mathrm{N}},(\mathrm{Gd} / \mathrm{Yb})_{\mathrm{N}},(\mathrm{La} / \mathrm{Yb})_{\mathrm{N}}, \mathrm{La} / \mathrm{Y}, \sum \mathrm{LREE}, \sum \mathrm{HREE}, \sum \mathrm{REE}$ with Ce and $\mathrm{Eu}$ anomalies in samples of Neysian copper deposits.

\begin{tabular}{|c|c|c|c|c|c|c|c|c|c|c|}
\hline Samples & $(\mathrm{La} / \mathrm{Sm})_{\mathrm{N}}$ & $(\mathbf{L a} / \mathbf{L u})_{N}$ & $(\mathbf{L a} / \mathrm{Yb})_{\mathrm{N}}$ & $(\mathbf{G d} / \mathbf{Y b})_{\mathbf{N}}$ & $\mathrm{Ce} / \mathrm{Ce} *$ & Eu/Eu* & $\mathbf{L a} / \mathbf{Y}$ & $\sum$ LREE & $\sum$ HREE & $\sum$ REE \\
\hline K1 & 2.57 & 10.21 & 6.94 & 1.197 & 1.33 & 0.98 & 1.36 & 80.31 & 7.18 & 87.49 \\
\hline K2 & 2.58 & 11.06 & 7.51 & 0.99 & 1.34 & 1.26 & 0.98 & 63.92 & 7.04 & 70.96 \\
\hline K3 & 3.05 & 6.22 & 5.39 & 1.00 & 0.88 & 1.15 & 0.98 & 59.17 & 8.44 & 67.61 \\
\hline K4 & 6.37 & 16.05 & 10.90 & 1.45 & 0.6 & 1.45 & 2.32 & 67.38 & 7.42 & 74.8 \\
\hline K5 & 3.58 & 9.67 & 6.94 & 0.62 & 1 & 1.39 & 1.72 & 80.33 & 8.27 & 88.6 \\
\hline K6 & 5.41 & 30.35 & 32.43 & 3.24 & 0.88 & 1.07 & - & 157.49 & 9.17 & 166.66 \\
\hline K7 & 7.25 & 36.51 & 47.99 & 2.40 & 0.84 & 1.01 & - & 153.04 & 4.2 & 157.24 \\
\hline K8 & 5.13 & 17.74 & 18.90 & 2.14 & 0.86 & 1 & - & 104.75 & 8.05 & 112.8 \\
\hline K9 & 4.17 & 2.69 & 5.90 & 1.07 & 0.9 & 0.9 & - & 93.85 & 18.11 & 111.96 \\
\hline K10 & 3.94 & 6.28 & 6.53 & 1.32 & 0.52 & 0.08 & 0.98 & 56.93 & 10.95 & 67.88 \\
\hline Ph-1 & 2.45 & 3.71 & 2.77 & 0.88 & 0.54 & 0.61 & 0.59 & 50.36 & 11.15 & 61.51 \\
\hline$\underline{\mathbf{S i}}$ & 7.62 & 23.42 & 21.21 & 1.29 & 0.83 & 0.66 & - & 47.61 & 3.23 & 50.84 \\
\hline
\end{tabular}

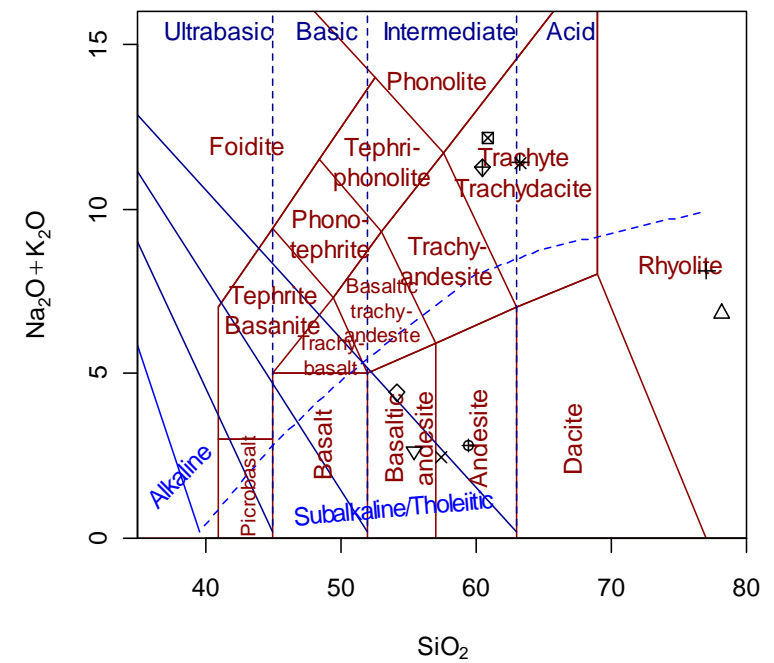

Fig. 18 Position of Neysian data points on bivariate $\mathrm{Na}_{2} \mathrm{O}+\mathrm{K}_{2} \mathrm{O}-\left(\mathrm{SiO}_{2}\right)$ chart (Cox et al., 1979).

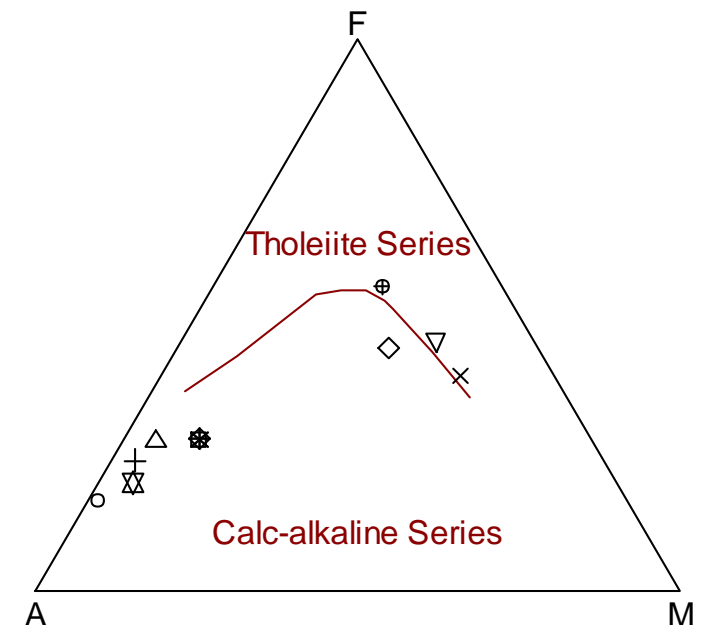

Fig. 19 Position of Neysian data points on ternary AFM plot (Irvin and Baraga, 1971). 


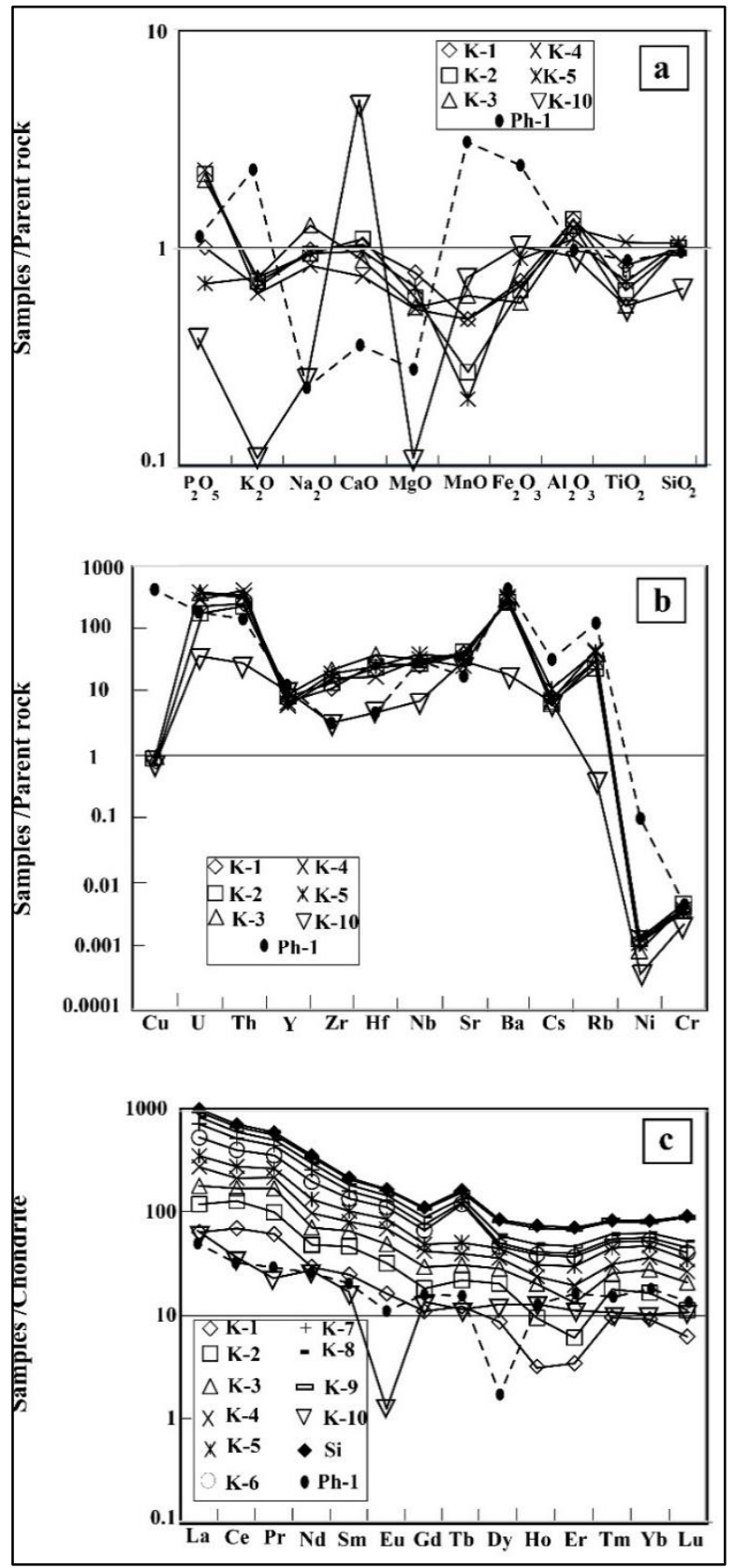

Fig. 20 a) Diagram of normalized major and minor oxides of altered rocks to fresh volcanic rocks in Neysian copper deposit, b) Diagram of normalized trace elements of altered rocks to fresh volcanic rocks, c) Diagram of normalized REEs of altered rocks and silicic tuff to chondrite (Sun and McDonough., 1989).

nonresistant minerals into clay minerals. Depletion of REEs in study samples related to low $\mathrm{pH}$ of fluid responsible for alteration.

Discrepancy in the amount of REEs depletion and enrichment during argillitization, is due to change in the $\mathrm{pH}$ of the fluids by two mechanisms: presence of two alteration fluids with different $\mathrm{pH}$ (the hypogene fluid with $\mathrm{pH}$ below 2 and meteoric water with $\mathrm{pH}$ between 4 to 9) and decrease in temperature of hypogene fluid. These factors can cause instability in the REEs complexes. Depletion of Fe and Ti during kaolinization with a very low values of $\mathrm{Sr}+\mathrm{Ba}$ and low values of $\mathrm{La}+\mathrm{Y}+\mathrm{Ce}$ indicate the hypogene source of fluid responsible for alteration (Abedini and Calagari, 2015). In this regard, the Neysian is similar to Biga Peninsula kaolin deposit in Turkey (Kadir and Erkoyun., 2013), Swat kaolin deposit in Pakistan (Siddiqui and Ahmed, 2008), and Abgarm Mianeh in Iran (Abedini and Calagari, 2015).

In the bivariate plot of $\mathrm{Ti}+\mathrm{Fe}-\mathrm{Cr}+\mathrm{Ni}$ (Dill et al., 2000), the samples plot in the hypogene field (Fig. 21a). With the use of the bivariate $\mathrm{Sr}+\mathrm{Ba}-\mathrm{Cr}+\mathrm{Ni}$ diagram (Dill et al., 2000), the Neysian alteration system is supported by mixing of hypogene and supergene processes (Fig. 21b). If the $\mathrm{TiO}_{2}$ concentration is less and greater than one that is related to hypogene and supergene kaolin deposits respectively. In all Neysian kaolin samples the concentration of $\mathrm{TiO}_{2}$ are less than 1, so it seems kaolinitization in Neysian is related to hypogene fluids. Eu and $\mathrm{Ce}$ anomalies vary from 0.08 to 1.45 and 0.52 to 1.34 respectively. Eu and $\mathrm{Ce}$ anomalies are controlled by different intensity of feldspar alteration and change in oxidation conditions respectively.

The lowest amount of $\mathrm{La} / \mathrm{Y}(0.59)$ is for sample from phyllic zone (Ph- 1). It varies from 0.98 to 2.32 for argillic samples zone. It indicates that phyllic alteration zone precipitated in more acidic condition than argillic alteration zone (Table 12). The values of Pearson correlation coefficients (Rollinson, 1993) between $\mathrm{Ce} / \mathrm{Ce}^{*}, \quad \mathrm{Eu} / \mathrm{Eu}^{*}, \quad(\mathrm{La} / \mathrm{Yb})_{\mathrm{N}}, \quad(\mathrm{Gd} / \mathrm{Yb})_{\mathrm{N}}$ $(\mathrm{La} / \mathrm{Lu})_{\mathrm{N}},(\mathrm{La} / \mathrm{Sm})_{\mathrm{N}}$ and $\mathrm{La} / \mathrm{Y}$ with some of major and minor oxides and trace elements in Neysian copper deposit show in Table 13.

There is a positive correlation between $\mathrm{Ce}$ anomaly and $\mathrm{Cr}$ and $\mathrm{Ni}(\mathrm{r}=0.69$ and 0.77$)$ and $\mathrm{Al}_{2} \mathrm{O}_{3}$ and $\mathrm{SiO}_{2}(\mathrm{r}=0.74$ and 0.48$)$ (Table 13). It seems that distribution of $\mathrm{Ni}$ and $\mathrm{Cr}$ - bearing minerals and clay minerals can control the Ce anomaly in the Neysian alteration system.

\subsection{COMPARISON OF GEOLOGICAL, MINERALOGICAL AND GEOCHEMICAL CHARACTERISTICS OF THE BARZAVAND AND NEYSIAN COPPER DEPOSITS}

The strata- bound copper deposits in Chile are hosted by volcanic and volcano- sedimentary sequences of Jurassic to Lower Cretaceous age, which were accumulated in intra- arc basins (Boric et al., 2002). Among the strata- bound deposits, the copper (silver) family, also known as "Mantos" or "Mantotype copper deposit" in the literature, are better understood. The Barzavand copper deposit has a strata-bound form with Oligo- miocene age.

This family of deposits usually has high copper grade $(1.5-2 \% \mathrm{Cu})$, relatively low contents of silver (5-20 g/t) and are practically devoid of gold (Boric et al., 2002). In Barzavand copper deposits average of copper and silver are $3.87 \%$ and $17.4 \mathrm{ppm}$ 


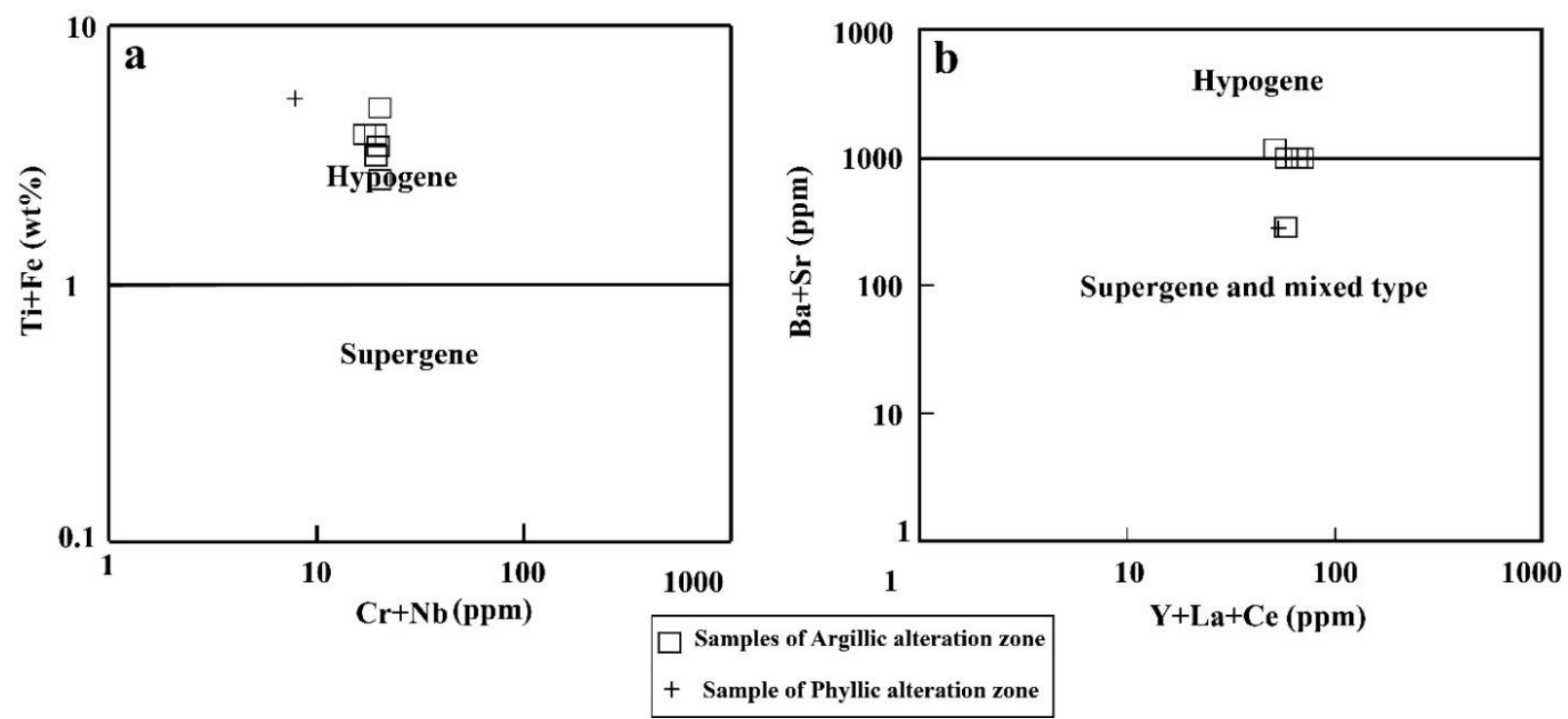

Fig. 21 Position of samples of argillic and phyllic in bivariate chart a) $\mathrm{Ti}+\mathrm{Fe}-\mathrm{Cr}+\mathrm{Nb}$ (Dill et al., 2000), b) $\mathrm{Ba}+\mathrm{Sr}-\mathrm{Y}+\mathrm{La}+\mathrm{Ce}$ (Dill et al., 2000).

Table 13 The values of Pearson correlation coefficients (Rollinson, 1993) between $(\mathrm{Ce} / \mathrm{Ce})^{*},(\mathrm{Eu} / \mathrm{Eu})^{*},(\mathrm{La} / \mathrm{Yb})_{\mathrm{N}}$, $(\mathrm{Gd} / \mathrm{Yb})_{\mathrm{N}}(\mathrm{La} / \mathrm{Lu})_{\mathrm{N}},(\mathrm{La} / \mathrm{Sm})_{\mathrm{N}}$ and $\mathrm{La} / \mathrm{Y}$ with some of major and minor oxides and trace elements in Neysian copper deposit.

\begin{tabular}{lccccrrr}
\hline & $\mathbf{E u} / \mathbf{E u}$ & $\mathbf{C e} / \mathbf{C e}$ & $(\mathbf{L a} / \mathbf{L u})_{\mathbf{N}}$ & $(\mathbf{L a} / \mathbf{S m})_{\mathbf{N}}$ & $(\mathbf{L a} / \mathbf{Y b})_{\mathbf{N}}$ & $(\mathbf{G d} / \mathbf{Y b})_{\mathbf{N}}$ & $\mathbf{L a} / \mathbf{Y}$ \\
\hline $\mathbf{S i O}_{2}$ & 0.98 & 0.48 & 0.53 & 0.04 & 0.29 & -0.38 & 0.44 \\
$\mathbf{T i O}_{2}$ & 0.51 & -0.06 & 0.92 & 0.67 & 0.89 & 0.44 & 0.02 \\
$\mathbf{A l}_{2} \mathbf{O}_{3}$ & 0.68 & 0.74 & 0.42 & -0.29 & 0.15 & -0.06 & 0.18 \\
$\mathbf{F e}_{2} \mathbf{O}_{3}$ & -0.70 & -0.46 & -0.33 & 0.11 & -0.13 & 0.01 & -0.57 \\
$\mathbf{F e O}$ & 0.92 & 0.67 & 0.50 & -0.15 & 0.21 & -0.38 & 0.28 \\
$\mathbf{M n O}$ & 0.03 & -0.18 & -0.06 & 0.12 & -0.05 & 0.48 & 0.51 \\
$\mathbf{M g O}$ & 0.79 & 0.77 & 0.39 & -0.29 & 0.09 & -0.42 & 0.00 \\
$\mathbf{C a O}$ & -0.95 & -0.53 & -0.52 & 0.02 & -0.26 & 0.33 & -0.42 \\
$\mathbf{N a}_{2} \mathbf{O}$ & 0.78 & 0.54 & 0.12 & -0.28 & -0.13 & -0.43 & 0.53 \\
$\mathbf{K} \mathbf{O}$ & 0.92 & 0.63 & 0.37 & -0.19 & 0.09 & -0.50 & 0.38 \\
$\mathbf{P}_{2} \mathbf{O} 5$ & 0.63 & 0.13 & 0.50 & 0.23 & 0.42 & 0.20 & 0.69 \\
$\mathbf{C r}$ & 0.77 & 0.77 & 0.19 & -0.45 & -0.10 & -0.51 & 0.32 \\
$\mathbf{N i}$ & 0.86 & 0.69 & 0.57 & -0.13 & 0.29 & -0.51 & -0.03 \\
$\mathbf{R b}$ & 0.92 & 0.21 & 0.65 & 0.33 & 0.48 & -0.26 & 0.39 \\
$\mathbf{C s}$ & 0.35 & 0.16 & 0.14 & 0.01 & 0.04 & -0.66 & -0.28 \\
$\mathbf{B a}$ & 0.97 & 0.46 & 0.60 & 0.09 & 0.36 & -0.30 & 0.39 \\
$\mathbf{S r}$ & 0.11 & 0.82 & -0.45 & -0.93 & -0.68 & -0.50 & -0.09 \\
$\mathbf{N b}$ & 0.96 & 0.35 & 0.43 & 0.08 & 0.22 & -0.55 & 0.49 \\
$\mathbf{H f}$ & 0.61 & 0.58 & -0.12 & -0.47 & -0.37 & -0.49 & 0.43 \\
$\mathbf{Z r}$ & 0.84 & 0.21 & 0.17 & 0.02 & 0.00 & -0.53 & 0.74 \\
$\mathbf{Y}$ & -0.79 & -0.24 & -0.81 & -0.39 & -0.65 & 0.09 & -0.04 \\
$\mathbf{T h}$ & 0.94 & 0.14 & 0.63 & 0.37 & 0.47 & -0.20 & 0.57 \\
$\mathbf{U}$ & 0.81 & 0.17 & 0.20 & 0.08 & 0.03 & -0.53 & 0.60 \\
$\mathbf{C u}$ & -0.70 & 0.14 & -0.56 & -0.52 & -0.52 & 0.40 & -0.34 \\
\hline
\end{tabular}

respectively. Only in B2 sample from Barzavand copper deposit, the gold concentration approximately is 2 ppm. It is probably having scientific significance for gold exploration (especially in other faults and fractures with E-W trend, near the major Kachumesqal and Zafarqand faults).

These deposits are only strata- bound in a regional scale, it means that they are epigenetic, and although the ores are restricted to certain stratigraphic units, in detail they are discordant; their ore bodies are structurally controlled or follow relatively permeable horizons in the strata. In the Barzavend copper deposit, $\mathrm{Cu}$ - mineralization extended only in basalt. Hypogene mineralogy is relatively simple and consists of bornite, chalcocite ( \pm digenite), chalcopyrite, pyrite and hematite (Boric et al., 2002). In the Barzavand copper deposit hypogene mineralogy consists of chalcopyrite, bornite, and pyrite. 
Alteration in Manto- type copper deposits mostly include propylitization, albitization, silicification and calcification (Maksaev and Zentilli, 2002). Alteration in Barzavand copper deposit includes propylitizatin, albitization, silicification and calcification. $\mathrm{Cu}$-mineralization occurs in special parts of host rock such as fractures and amygdaloidal cavities (Kojima et al., 2009). In the Barzavand copper deposit, $\mathrm{Cu}$-mineralization extends in fractures and basalt cavities with amygdaloidal texture. The sulphide ores tend to occur in reduced (probably submarine) strata rather than in oxidized (sub- aerial) strata, most authors suggest that oxi-reduction reactions were important in their genesis. Supergene metal enrichment is related to surficial weathering which has been a significant factor in making some economic porphyry copper deposits. It is not a main factor in the Manto -type copper deposit, although oxidized ores are exploited in many kinds of them. In Barzavand copper deposits hematite, goethite, malachite, azurite and malachite formed by the weathering process.

Gangue minerals are relatively scarce and the effects of hydrothermal alteration are difficult to distinguish from low-grade regional metamorphic assemblages. The genesis of these Manto- type copper deposits has been the subject of much controversy, with the proposed genetic models ranging from volcanogenic syngenetic (Ruiz and Peebles, 1988). Through another hypotheses, fluids released during low-grade metamorphism of the volcanic units (Sillitoe, 1992), or fluids directly derived from granitoid plutons (Klohn et al., 1990), or combination of these last two mechanisms (Fontboté, 1990).

It seems three main stages can be considered during formation of Barzavand copper deposit include: 1) pre- mineralization stage including volcanic activity and eruption of tuffs and basalt with propylitic alteration (occur during circulation of seawater in fractures and cavities of basalt). Pyrite forms from sulfate- reducing bacteria activities. Framboidal pyrite as a biological activity is formed under the water surface and in reduced conditions. Also, seawater can trap in the basalt cavities in this stage. 2) Mineralization stage: Brine fluids derived from related diagenesis of the tuff sequence, leached various metals from suitable minerals and redeposit them in the basalt. So, the $\mathrm{Fe}^{2+}$ - bearing minerals formed through volcanic activity (such as magnetite and biotite) and disseminated pyrite can reduce the redox potential of brine fluid. Also, trapped seawater in basalt cavities causes dilution and reduction of brine fluids temperature. Propylitization in the pre-mineralization stage can increase the brine fluids $\mathrm{pH}$. These factors control the metal precipitation in host rock and 3) post mineralization stage including weathering and supergene activities. Goethite, hematite, malachite and azurite formed in this stage.

In Manto- type copper deposits, $\mathrm{Cu}$ transported by chloride complexes Also, fluid with near neutral $\mathrm{pH}$ and high fugacity oxygen are able to increase $\mathrm{Cu}$ solubility (Wilson and Zentilli, 2006). In most study samples of Barzavand copper deposit, the $\mathrm{La} / \mathrm{Y}$ ratio is less than one. It indicates the acidic $\mathrm{pH}$ of fluids responsible for mineralization. In Barzavand copper deposit, Copper is transported by means of chloride complexes into oxidized brine fluids related to late diagenesis stage and precipitated by substitution within pyrites formed during the volcanism process. In Manto- type ore deposits, $\mathrm{Cu}$ source can be circulation of fluid and $\mathrm{Cu}$ leaching from volcanic and volcano-sedimentary rocks. Plutonic complex act as possible heat source to drive thermal convection of ore- forming fluids involved in Manto- type copper deposits (Kojima et al., 2009).

In rare cases, magmatic fluids are considered as ore- forming components in Manto- type Copper deposits (Kojima et al., 2009). In Zefreh, due to subduction of Neo - Tethys below Eurasian plate many intrusive bodies formed with late Eocene, Oligocene and Miocene (such as Zafarqand, Fesharak and Nasrand) that affected older units through hydrothermal fluids. They are able to produce porphyry copper deposits such as Kahang and Zafarqand. This study points out the importance of exploration of volcanic rocks hosted Manto- type copper deposits alongside plutonic rocks involved in porphyry copper deposits in Zefreh. According to mentioned items, we suggest exact study of plutonic complex, lithology of host rocks and study of oxygen and hydrogen isotopes to determine role of magmatic fluids as possible source of fluids in formation of Manto- type Copper deposits in study area. In Table 14, the Barzavand copper deposit has been compared with the Manto- type ore deposits, Red bed, and Michigan copper deposits. According to alteration properties, mineralogy and the Whole- rock geochemistry, the Barzavand copper deposit is most similar to Manto- type copper deposits.

Different porphyry copper deposits (such as Kahang, about $7 \mathrm{~km}$ from the Neysian copper deposit) occur in association with the Zefreh fault. The Zefreh fault provides enough open space for intrusion of stocks with Oligo- miocene age. In Neysian, intrusion of granodiorite stock with Oligo- miocene age into volcanic and volcano- sedimentary units with Eocene age cause formation of various type of alteration such as phyllic, advanced argillic, argillic and propylitic. The alteration system has an oval form with an average diameter of about $2.5 \mathrm{~km}$. The largest part of argillic alteration is buried under quaternary sediments or mixed by them.

The phyllic alteration zone is formed during hydrolysis of igneous rocks and leaches the different cations such as $\mathrm{K}^{+}, \mathrm{Na}^{+}, \mathrm{Ca}^{2+}, \mathrm{Mg}^{2+}, \mathrm{Fe}^{2+}$ and $\mathrm{SiO}_{4}{ }^{4}$. In these conditions' sericite, kaolinite, dickite, quartz and pyrite can precipitate. Formation of sericite occurs according to the following equation (Shahabpour, 2001):

$$
\mathrm{K} \text { - feldspar }+\mathrm{Haq}^{+}+\ldots \rightarrow \text { Sericite }+\mathrm{K}_{\mathrm{aq}}{ }^{+}+\mathrm{SiO}_{2}
$$


Table 14 Compersion of Barzavand copper deposit, Manto - type copper deposit, Redbed- type copper deposit and Michigan copper deposit.

\begin{tabular}{|c|c|c|c|c|}
\hline Mineralization properties & Barzavand & Manto- type copper deposit & Redbed- type copper deposit & Michigan copper deposit \\
\hline Age & Oligo - miocene & Late jurrasic to early cretaceous & Protrozoic to tertiar & Precambrian \\
\hline Tectonic setting & Extensional environment & $\begin{array}{l}\text { Extensional environment related } \\
\text { to Andean subduction and back - } \\
\text { arc basin }\end{array}$ & $\begin{array}{c}\text { Intracontinental rift and near plate } \\
\text { margins }\end{array}$ & Subcontinental rift \\
\hline Alteration & $\begin{array}{l}\text { Propylitic, silicification, } \\
\text { calcification, albitization and } \\
\text { prehnitization }\end{array}$ & $\begin{array}{l}\text { Propylitic, silicification, } \\
\text { calcification and albitization }\end{array}$ & $\begin{array}{l}\text { Almost without alteration or } \\
\text { accompanied by prehnite - } \\
\text { pumpellyite metamorphism }\end{array}$ & $\begin{array}{l}\text { Almost without alteration or } \\
\text { accompanied by albitization, } \\
\text { calcification, chloritization, } \\
\text { epidotization, silicification and } \\
\text { formation of prehnite - } \\
\text { pumpellyite in wall rocks }\end{array}$ \\
\hline $\begin{array}{l}\text { Structure and texture of } \\
\text { host rock }\end{array}$ & $\begin{array}{l}\text { Porphyry, breccia and } \\
\text { amygdaloidal }\end{array}$ & $\begin{array}{l}\text { Porphyry, breccia, aphanitic and } \\
\text { amygdaloidal }\end{array}$ & Amigdaloidal and breccia & Amigdaloidal \\
\hline Type of mineralization & Hypogene & Hypogene & Hypogene & Hypogene \\
\hline Ore minerals & $\begin{array}{l}\text { Chalcopyrite, bornite, covellite, } \\
\text { malachite and azorite }\end{array}$ & $\begin{array}{l}\text { Chalcocite, digenite, bornite, } \\
\text { chalcopyrite and covellite }\end{array}$ & $\begin{array}{l}\text { Native copper, chalcocite, bornite, } \\
\text { digenite native silver, Fe- sulfides } \\
\text { (spatially pyrite) }\end{array}$ & $\begin{array}{c}\text { Native copper, native silver } \\
\operatorname{digg} \pm \text { malachit } \pm \text { chalcocite } \pm \text { azorite } \\
\pm \text { enite }\end{array}$ \\
\hline Gangue minerals & $\begin{array}{l}\text { Quartz, chlorite, hematite, } \\
\text { epidote, calcite, chalcedony, } \\
\text { prehnite and zeolite }\end{array}$ & $\begin{array}{l}\text { Quartz, chlorite, epidote, calcite } \\
\text { and zeolite }\end{array}$ & $\begin{array}{l}\text { Hematite, magnetite, calcite, } \\
\text { epidote, quartz, chlorite and } \\
\text { zeolite }\end{array}$ & $\begin{array}{l}\text { Calcite, epidote, quartz, chlorite } \\
\text { and zeolite }\end{array}$ \\
\hline Structure and ore texture & $\begin{array}{l}\text { Disseminated, veine and veinlet, } \\
\text { open space filling and } \\
\text { amygdaloidal }\end{array}$ & $\begin{array}{l}\text { Disseminated, vein and veinlet, } \\
\text { open space filling and } \\
\text { amygdaloidal }\end{array}$ & $\begin{array}{l}\text { Disseminated, vein and veinlet, } \\
\text { open space filling and substitution } \\
\text { texture }\end{array}$ & $\begin{array}{c}\text { Open space filling, massive and } \\
\text { disseminated }\end{array}$ \\
\hline Supergene enrichment & Few & Almost few & Few & Few \\
\hline Iron cap & Do not exist & Do not exist & Do not exist & Do not exist \\
\hline Samples & This study & $\begin{array}{l}\text { Mantos Blancos (Oliveros et al., } \\
\text { 2008); Lince-Estefania (Trista- } \\
\text { Aguilera et al., 2006); Northen } \\
\text { Chilean (Kojima et al., 2003) }\end{array}$ & $\begin{array}{l}\text { Mont Alexandre (Cabral and } \\
\text { Beaudoin, 2007); Hinds lake area } \\
\text { (Case and Zagorevski, 2009) }\end{array}$ & $\begin{array}{l}\text { White Pine (Brown, 1971; } \\
\text { Swenson and Person, 2000); } \\
\text { Copper Falls Mine (Larsen et al., } \\
\text { 2003); Houghton County } \\
\text { (Rosemeyer, 2011) }\end{array}$ \\
\hline
\end{tabular}


In the Neysian copper deposit, phyllic alteration zone extends in granodiorite and includes quartz+sericite and pyrite.

The advanced argillic zone consists of pyrophyllite, diaspore and alunite minerals. Alunite and diaspore may form according to the following equations (Shahabpour, 2001):

$$
\begin{array}{cc}
\mathrm{KAl}_{3} \mathrm{SiO}_{10}(\mathrm{OH})_{2}+2 \mathrm{SO}_{4}^{-2}+4 \mathrm{H}^{+} \rightarrow \mathrm{KAl}_{3}\left(\mathrm{SO}_{4}\right)_{2}(\mathrm{OH})_{6}+\mathrm{SiO}_{2} \\
\text { Sericite } & \text { Alunite } \\
3 \mathrm{KAlSi}_{3} \mathrm{O}_{8}+6 \mathrm{H}^{+}+2 \mathrm{SO}_{4}^{-2} \rightarrow \mathrm{KAl}_{3}\left(\mathrm{SO}_{4}\right)_{2}(\mathrm{OH})_{6}+2 \mathrm{H}^{+}+9 \mathrm{SiO}_{2} \\
\text { Feldspar } & \text { Alunite } \\
2 \mathrm{AlO}(\mathrm{OH})+4 \mathrm{SiO}_{2} \rightarrow \mathrm{Al}_{2} \mathrm{SiO}_{10}(\mathrm{OH})_{2} \\
\text { Pyrophyllite } & \text { Diaspore }
\end{array}
$$

In Neysian copper deposits, the argillic zone is formed from the decomposition of shard glass and feldspars. Released silica can crystallize cristobalite or chalcedony forms according to the following equations (Shahabpour, 2001):

$$
\begin{array}{cc}
\mathrm{KAlSi}_{3} \mathrm{O}_{8}+2 \mathrm{H}^{+} \leftrightarrow & (\mathrm{Al}, \mathrm{Mg}, \mathrm{Fe})_{2}(\mathrm{Si}, \mathrm{Al})_{4} \mathrm{O}_{10}(\mathrm{OH})_{2}+\mathrm{SiO}_{2}+\mathrm{K}^{+} \\
(\mathrm{K}-\mathrm{fld}) & \text { (Montmorillonite) }
\end{array}
$$$$
\mathrm{NaAlSi}_{3} \mathrm{O}_{8}+\mathrm{H}^{+} \leftrightarrow(\mathrm{Al}, \mathrm{Mg}, \mathrm{Fe})_{2}(\mathrm{Si}, \mathrm{Al})_{4} \mathrm{O}_{10}(\mathrm{OH})_{2}+\mathrm{SiO}_{2}+\mathrm{Na}^{+}
$$

(Albite) (Montmorillonite)

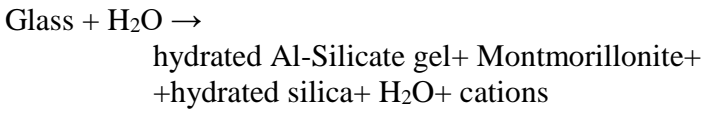

Propylitic alteration zone produced due to interaction between hydrothermal fluids including $\mathrm{Ca}^{2+}, \mathrm{Mg}^{2+}, \mathrm{Fe}^{2+}, \mathrm{CO}_{3}{ }^{2-}$ and igneous rocks. It is recognized by epidote, chlorite, calcite, albite and zoisite minerals (Shahabpour., 2001). In the Neysian copper deposit, propylitic alteration is located around the system and consists of chlorite and calcite from the decomposition of feldspars.

Geochemical studies show that the Neysian alteration system formed by mixing of hypogene and supergene fluids. Granodiorite stock can support the ascending hypogene fluids during degassing of large subjacent magma bodies. The descending meteoric water percolated to depths through faults, fractures, and primary permeable (e.g., pumice and ignimbrite) zones, increased their temperature, produce of convection flows, and have the capacity to alter the host rocks.

Porphyry deposits are large, low- to mediumgrade deposits in which primary (hypogene) ore minerals are often structurally controlled which are spatially and genetically related to felsic to intermediate porphyritic intrusions (Kirkham, 1971). In the Neysian copper deposit, hypogene fluid plays an important role in mineralization. This deposit is structurally controlled by the Zefreh fault and genetically is related to granodiorite stock. The large size and structural control used to distinguish porphyry deposits (Sinclair, 2007). In the Neysian copper deposit, fracture, vein, stockwork, and the breccia zone are recognized. Porphyry $\mathrm{Cu}$ deposits typically occur in the root zones of andesitic stratovolcanoes in subduction-related, continental and island- arc settings (Sillitoe, 1973). Neysian copper mineralization has been formed in the subduction zone.

Hydrothermal alteration is extensive and typically zoned on a deposit scale (Lowell and Guilbert, 1970) as well as around individual veins and fractures. In many porphyry deposits, alteration zones on a deposit scale consist of an inner potassic zone and an outer zone of propylitic alteration. Phyllic alteration and argillic alteration zones may be part of the zonal pattern between the potassic and propylitic zones. The alteration system in Neysian has zonal pattern and include from inner to outer: Phyllic (sericite, quartz and pyrite), advanced argillic (quartz, diaspore, alunite and montmorillonite), argillic (kaolinite, jarosite, pyrite, montmorillonite and gypsum) and propylitic (calcite and chlorite). The Neysian copper deposit has not deep drilling to identify the potassic alteration zone. In the Neysian area alteration properties, mineralogy, tectonic setting, structural control system, texture, source of fluid responsible for alteration and Whole- Rock geochemistry could be used as an exploration target for porphyry copper mineralization. In Table 15, the Neysian copper deposit is compared with other porphyry copper deposits.

\section{CONCLUSIONS}

1. In the northwest of Naein, there is various faults, generally with three trends include: NW-SE (such as Zefreh, Ardestan, Marbin and Kashan faults), E-W (such as Zafarqand and Kachumesqal faults) with alteration and $\mathrm{Cu}$-mineralization and NW-SE without alteration.

2. In the Barzavand area, the alteration process with Oligo- miocene age occurs along the tension E-W fault. The alteration zone is restricted to certain stratigraphic units (basalt) and includes propylitazation, silicification, pyritization, saussuritization and uralitization. The average grade of $\mathrm{Cu}$ in tuffs is $524 \mathrm{ppm}$ and has enough potential as a source of copper. Barzavand copper deposit has four stages during its evolution, including: volcanism, diagenesis, metamorphism and weathering. By diagenesis of tuff sequence, brine fluids released and leached various metals from suitable minerals and redeposited them in the basalt. Copper is transported by means of chloride complexes into oxidized brine fluids related to late diagenesis stage and precipitated by substitution within pyrites formed during the volcanism process.

3. In the Neysian area, intrusion of granodiorite stock with Oligo-miocene age within Eocene units (volcanic and volcano-sedimentary units) along Zefreh fault, cause the various type of alteration with zonal pattern from inner to outer: phyllic, advanced argillic, argillic and propyllitic respectively. There is no deep drilling in the Neysian copper deposit to identify the potassic zone. 
Table 15 Compersion of Neysian, Sarcheshmeh, Kahang, Sungun, Bingham and El teniente porphyry copper deposits.

\begin{tabular}{|c|c|c|c|c|c|c|}
\hline Ore name & Neysian & Sarcheshmeh & Kahang & Sungun & Bingham & EL teniente \\
\hline Host rock & Granodiorite & $\begin{array}{l}\text { Granodiorite and } \\
\text { quartzmonzonite }\end{array}$ & $\begin{array}{l}\text { Diorite, quartzdiorite } \\
\text { and tonalite }\end{array}$ & $\begin{array}{c}\text { Monzonite, } \\
\text { quartzmonzonite, } \\
\text { diorite and } \\
\text { granodiorite } \\
\end{array}$ & $\begin{array}{l}\text { Monzonite and } \\
\text { quartzmonzonite }\end{array}$ & $\begin{array}{l}\text { Quartzdiorite, tonalite, } \\
\text { microdiorite and } \\
\text { andesite }\end{array}$ \\
\hline Tectonic setting & Subduction zone & Continental arc & Continental arc & Continental arc & Continental arc & Subduction zone \\
\hline Magma series & $\begin{array}{c}\text { Calc alkaline to } \\
\text { tholeiite }\end{array}$ & Calc alkaline & Calc alkaline & Calc alkaline & Calc alkaline & $\begin{array}{c}\text { Tholeiite to calc } \\
\text { alkaline }\end{array}$ \\
\hline Age & Oligo- miocene & Oligocene & Oligo - miocene & Oligo - miocene & $\begin{array}{l}\text { Late Eocene to } \\
\text { oligocene }\end{array}$ & Miocene - pliocene \\
\hline Alteration & $\begin{array}{c}\text { Phyllic, argillic and } \\
\text { propylitic }\end{array}$ & $\begin{array}{c}\text { Potassic, phyllic, } \\
\text { argillic and propylitic }\end{array}$ & $\begin{array}{c}\text { Potassic, phyllic, } \\
\text { argillic and propylitic }\end{array}$ & $\begin{array}{l}\text { Potassic, phyllic, } \\
\text { argillic and propylitic }\end{array}$ & $\begin{array}{c}\text { Potassic, phyllic, } \\
\text { argillic and propylitic }\end{array}$ & $\begin{array}{l}\text { Potassic, phyllic and } \\
\text { propylitic }\end{array}$ \\
\hline Metals & $\mathrm{Cu}$ & $\mathrm{Cu}, \mathrm{Mo}, \mathrm{Au}$ and $\mathrm{Ag}$ & $\mathrm{Cu}$ & $\mathrm{Cu}$ and $\mathrm{Mo}$ & $\mathrm{Cu}$ and $\mathrm{Mo}$ & $\mathrm{Cu}$ and $\mathrm{Mo}$ \\
\hline Ore minerals & $\begin{array}{l}\text { Chalcopyrite, pyrite, } \\
\text { malachite, azorite, } \\
\text { bornite, covellite, } \\
\text { hematite and goethite }\end{array}$ & $\begin{array}{l}\text { Chalcopyrite, pyrite, } \\
\text { molybdenite, } \\
\text { chalchocite, digenite } \\
\text { and covellite. }\end{array}$ & $\begin{array}{l}\text { Pyrite, chalcopyrite, } \\
\text { bornite, magnetite, } \\
\text { chalcocite and } \\
\text { covellite }\end{array}$ & $\begin{array}{c}\text { Pyrite, chalcopyrite, } \\
\text { bornite, chalcocite and } \\
\text { covellite }\end{array}$ & $\begin{array}{l}\text { Chalcopyrite, pyrite, } \\
\text { molybdenite, } \\
\text { calchocite, digenite } \\
\text { and covellite. }\end{array}$ & $\begin{array}{l}\text { Chalcopyrite, pyrite, } \\
\text { molybdenite, } \\
\text { calchocite, digenite, } \\
\text { native } \mathrm{Cu} \text {, cuprite and } \\
\text { covellite. }\end{array}$ \\
\hline Refrences & This study & $\begin{array}{l}\text { (Shahabpour, 2000; } \\
\text { Hezarkhani, 2006; } \\
\text { Shafiei and } \\
\text { Shahabpour, 2000) }\end{array}$ & (Komeili et al., 2017) & $\begin{array}{c}\text { (Calagari, 2004; } \\
\text { Asghari and } \\
\text { Hezarkhani, 2010) }\end{array}$ & $\begin{array}{l}\text { (Maughan et al., 2002; } \\
\text { Redmond et al., 2004; } \\
\text { Cunningham et al., } \\
\text { 2004; Phillips et al., } \\
\text { 2005; Core et al., 2006) }\end{array}$ & $\begin{array}{l}\text { (Sillitoe and Perelló, } \\
\text { 2005; Stern and } \\
\text { Skewes, 2005; Skewes } \\
\text { and Stern, 2007; } \\
\text { Codelco, 2007; } \\
\text { Klemm et al., 2007; } \\
\text { Skewes et al., 2005) }\end{array}$ \\
\hline
\end{tabular}


4. The positive correlation between $(\mathrm{La} / \mathrm{Lu})_{\mathrm{N}}$, $(\mathrm{La} / \mathrm{Yb})_{\mathrm{N}},(\mathrm{La} / \mathrm{Sm})_{\mathrm{N}}$ and $\mathrm{La} / \mathrm{Y}$ and $\mathrm{CaO}(\mathrm{r}=0.70$ to 0.96 ) indicate that propylitization of host rock basalt and increase in $\mathrm{pH}$ of fluid responsible for mineralization play an important role in the differentiation of lanthanides in Barzavand copper deposit.

5. With the use of a bivariate diagram, $\mathrm{Sr}+\mathrm{Ba}-\mathrm{Ce}+\mathrm{Y}+\mathrm{La}$, the Neysian alteration system is supported by mixing of hypogene and supergene processes.

6. In Barzavand copper deposit the $\mathrm{La} / \mathrm{Y}$ ratio is less than one. It seems that copper transported by chloride ligands and precipitated by decrease in fluid redox potential and fluid temperature, but in Neysian copper deposit, the lowest amount of $\mathrm{La} / \mathrm{Y}$ ratio (0.59) is for sample from phyllic alteration zone. It varies from 0.98 to 2.32 for samples from argillic zone. It indicates that phyllic alteration zone precipitated in more acidic conditions than argillic alteration zone.

7. Adsorption of $\mathrm{Cu}-\mathrm{Zn}$ and $\mathrm{Pb}$ - bearing minerals by montmorillonite in argillic alteration zone of Neysian area, can be considered as an exploration target to find potential resources of metals. Also, presence of cesium in montmorillonite lattice and monazite indicate the scientific significance of Neysian copper deposit for exploration of trace and rare earth elements host minerals.

8. According to alter pe and porphyry copper deposits respectively. ation properties, mineralogy and the Whole- Rock geochemistry, the Barzavand and Neysian copper deposits are most similar to Manto- tyThey could be used as an exploration targets for copper mineralization.

\section{ACKNOWLEDGEMENT}

This article is a part of the result of Mr. Shahram Mobaser Ph.D. thesis who works in Islamic Azad University, Mahallat branch - Iran. The authors would like to express their thanks and appreciation to the authorities of this bureau. Our gratitude is further expressed to editors and reviewers.

\section{REFERENCES}

Abedini, A.: 2017, Geochemistry of argillic alteration: a case study from the Jizvan area, Tarom-Hashtjin zone. J. Geosci., 26, 104, 3-16. DOI: $10.22071 /$ gsj.2016.50099

Abedini, A. and Calagari, A.A.: 2015, Geochemical charecteristics of the Abgarm kaolin deposit, NW Iran. Neues Jahrb. Geol. Paläontol. Abh., 278, 335-350. DOI: $10.1127 / \mathrm{njgpa} / 2015 / 0533$

Abedini, A. and Rezaei Azizi, M.: 2019, The Hizeh- Jan kaolin deposit of NW Iran: the tetrad effect in REE distribution patterns. Acta Geol. Sin.- Engl., 93, 1, 7487. DOI: $10.1111 / 1755-6724.13765$
Abedini, A., Rezaei Azizi, M. and Calagari, A.A.: 2018, The lanthanide tetrad effect in argillic alteration: An example from the Jizvan district, northern Iran. Acta Geol. Sin., 92, 4, 1468-1485. DOI: $10.1111 / 1755-6724.13638$

Abedini, A., Rezaei Azizi, M. and Dill, H.G.: 2020, The tetrad effect in REE distribution patterns: A quantitative approach to genetic issues of argillic and propylitic alteration zones of epithermal $\mathrm{Cu}-\mathrm{Pb}-\mathrm{Fe}$ deposits related to andesitic magmatism (Khan Kandi District, NW Iran). J. Geochem. Explor., 212, 106516. DOI: 10.1016/j.gexplo.2020.106516

Asghari, O. and Hezarkhani, A.: 2010, Investigations of alteration zones based on fluid inclusion microthermometry at Sungun porphyry copper deposit, Iran. Maden Tetkik ve Arama Dergisi, 140, $140,19-34$.

https://dergipark.org.tr/en/pub/bulletinofmre/issue/3958/52

Babazadeh, S., Ghalamghash, J., D'Antonio, M. and Furman, T.: 2021, Hydrothermal alteration in Eshtehard volcanoes, Iran: Constraints from trace elements redistribution and stable isotope geochemistry. J. Geochem. Explor., 222, 106719. DOI: $10.1016 /$ j.gexplo.2020.106719

Baluchi Anaraki, T. and Mackizadeh, M.A.: 2013, Petrography, geochemistry and genesis of Fe- Skarn. Southwest of Ardestan, Central Iran. First virtual conference of Geology Sciences. Urmia, (in Persian).

Behyari, M., Rezaei Azizi, M. and Abedini, A.: 2020, The role of the structures on the fluorite mineralization: Insight to fluid inclusion and alteration map of the Laal-kan fluorite deposit, NW Iran. Acta Geodyn. Geomater, 17, 3(199), 379-390. DOI: 10.13168/AGG.2020.0028

Beygi, S., Nadimi, A. and Safaei, H.: 2016, Tectonics history of seismogenic fault structures in Central Iran. J. Geosci., 61, 2, 127-144. DOI: 10.3190/jgeosci.212.

Boric, R., Holmgren, C., Wilson, N.S.F. and Zentilli, M.: 2002, The geology of the El Soldado Manto- Type $\mathrm{Cu}$ (Ag) deposit, Central Chile. In: Porter, T.M. (Ed.), Hydrothermal Iron Oxide Copper-Gold \& Related Deposits: A Global Perspective, 2. PGC Publishing, Adelaide, 185-205.

Brown, A.C.: 1971, Zoning in the White Pine copper deposit, Ontonagon County, Michigan. Econ. Geol., 66, 4, 543-573. DOI: 10.2113/gsecongeo.66.4.543

Cabral, A.R. and Beaudoin, G.: 2007, Volcanic red-bed copper mineralization related to submarine basalt alteration, Mont Alexandre, Quebec Appalachians, Canada. Miner. Depos., 42, 901-912. DOI: $10.1007 / \mathrm{s} 00126-007-0141-7$

Calagari, A.A.: 2004, Fluid inclusion studies in quartz veinlets in the porphyry copper deposit at Sungun, East-Azarbaidjan, Iran. J. Asian Earth Sci., 23, 2, 179189. DOI: $10.1016 / \mathrm{S} 1367-9120(03) 00085-3$

Case, G. and Zagorevski, A.: 2009, Volcanic red-bed copper mineralization in the Hinds Lake area, central Newfoundland. Geol. Surv. Rep., 09-1, 131-146.

Christidis, G.E.: 2008, Validity of the structural formula method for layer charge determination of smectite: A re-evaluation of published data, Appl. Clay Sci., 42, 17. DOI: 10.1016/j.clay.2008.02.002 
Core, D.P., Kesler, S.E. and Essene, E.J.: 2006, Unusually $\mathrm{Cu}$-rich magmas associated with giant porphyry copper deposits-Evidence from Bingham, Utah. Geology, 34, 1, 41-44. DOI: 10.1130/G21813.1

Cox, K.G., Bell, J.D. and Pankhurst, R.J.: 1979, The interpretation of igneous rocks. George Allen and Unwin, London, 450.

DOI: 10.1007/978-94-017-3373-1

Craveiro, G.S., Xavier, R.P. and Villas, R.N.N.: 2019, The Cristalino IOCG deposit: an example of multi-stage events of hydrothermal alteration and copper mineralization. Braz. J. Geol., 49, 1. DOI: 10.1590/2317-4889201920180015

Cunningham, C.G., Austin, G.W., Naeser, C.W., Rye, R.O., Ballantyne, G.H., Stamm, R.G. and Barker, C.E.: 2004, Formation of a paleothermal anomaly and disseminated gold deposits associated with the Bingham Canyon porphyry Cu-Au-Mo system, Utah. Econ. Geol., 99, 4, 789-806. DOI: 10.2113/99.4.789

Dill, H.G., Bosse, H.R. and Kassbohm, J.: 2000, Mineralogical and chemical studies of volcanicrelated argillaceous industrial minerals of central American Cordillera (Western El Salvador), Econ. Geol., 95, 517-538.

DOI: 10.2113 /gsecongeo.95.3.517

Eliason, J.R.: 1966, Montmorillonite exchange equilibra with strontium- sodium- cesium, Am. Mineral., 51, 324-335.

Evensen, G.R., Hamilton, P.J. and Onions, R.K.: 1978, Rare earth abundances in chondritic meteorites. Geochim. Cosmochim. Acta, 42, 1199-1212.

Fatahi, Sh., Calagari, A.A. and Abedini, A.: 2016, Mineralogy and geochemistry of Neyestanak bentonite deposit, northwest of Naeen, Isfehan province. J. Geosci., 25, 98, 405-414. DOI: $10.22071 /$ gsj.2016.41271

Fatahi, Sh., Mackizadeh, M.A. Khani, N. and Bayat, S.: 2020, Mineralogy, geochemistry and genesis of Mollaahmad Pass bentonite deposit, Naein, Isfahan Province, Iran. Acta Geodyn. Geomater., 17, 1(197), 61-87. DOI: 10.13168/AGG.2020.0005

Fontboté, L.: 1990, Stratabound ore deposits in the Andes: A review and a classification according to their geotectonic setting. In: Fonbote, L., Amstutz, G.C., Cardozo, M., Cedillo, E. and Frutos,J., (eds.), Stratabound ore deposits in the Andes, 79-110. DOI:10.1007/978-3-642-88282-1_4

Hezarkhani, H.: 2006, Hydrothermal evolution of the SarCheshmeh porphyry $\mathrm{Cu}-\mathrm{Mo}$ deposit, Iran: evidence from fluid inclusions. J. Asian Earth Sci., 28, 409-422. DOI: 10.1016/j.jseaes.2005.11.003

Huang, X.W., Boutroy, É., Makvandi, S., Beaudoin, G., Corriveau, L. and De Toni A. F.: 2019, Trace element composition of iron oxides from IOCG and IOA deposits: relationship to hydrothermal alteration and deposit subtypes. Miner. Depos., 54, 4, 525-552. DOI: $10.1007 / \mathrm{s} 00126-018-0825-1$

Irvine, T.N. and Baragar, W.R.A.: 1971, A guide to the chemical classification of the common volcanic rocks. Can. J. Earth Sci., 8, 523-548.

Kadir, S. and Erkoyun, H.: 2013, Genesis of the hydrothermal Karacayir kaolin deposit in Miocene volcanics and Paleoozoic metamorphic rocks of the Uska- Gure Basin, western Turkey. Turkish J. Earth Sci., 22, 444-468. DOI: 10.3906/yer-1112-2
Kirkham, R.V.: 1971, Intermineral intrusions and their bearing on the origin of porphyry copper and molybdenum deposits: Econ. Geol., 66, 1244-1250. DOI: $10.2113 /$ gsecongeo.66.8.1244

Klemm, L.M. Pettke, T., Heinrich, C.A. and Campos, E.: 2007, Hydrothermal evolution of the El Teniente deposit, Chile: Porphyry Cu-Mo ore deposition from low-salinity magmatic fluids. Econ. Geol., 6, 10211045. DOI: 10.2113 /gsecongeo.102.6.1021

Klohn, E., Holmgren, C. and Ruge, H.: 1990, El Soldado, a Stratabound copper deposit associated with alkaline volcanism in the Central Chilean coastal range. In: Fonbote, L., Amstutz, G.C., Cardozo, M., Cedillo, E. and Frutos, J., (eds., Stratabound ore deposits in the Andes. 435-448. DOI: $10.1007 / 978-3-642-88282-1 \_33$

Kojima, S., Astudillo, J., Rojo, J., Trista', D. and Hayashi, K.: 2003, Ore mineralogy, fluid inclusion, and stable isotopic characteristics of stratiform copper deposits in the coastal Cordillera of northern Chile. Miner. Depos., 38, 208-216.

DOI: 10.1007/s00126-002-0304-5

Kojima, S., Trista-Aguilera, D. and Hayashi, K.: 2009, Genetic aspects of the Manto-type copper deposits based on geochemical studies of North Chilean deposits. Resour. Geol., 59, 1, 87-98. DOI: 10.1111/j.1751-3928.2008.00081.x

Komeili, S., Khalili, M., Asadi Haroni, H., Bagheri, H. and Ayati, F.: 2017, The nature of hydrothermal fluids in the Kahang porphyry copper deposit (Northeast of Isfahan) based on mineralography, fluid inclusion and stable isotopic data. Econ. Geol., 8, 2, 285-305, (in Persian). DOI: $10.22067 /$ econg.v8i2.37178

Kretz, R.:1983, Symbols for rock-forming minerals. Am. Mineral., 68, 277-279.

Larson, P.B., Maher, K., Ramos F.C., Chang, Z., Gaspar, M. and Meinert, L.D.: 2003, Copper isotope ratios in magmatic and hydrothermal ore-forming environments. Chem. Geol., 201, 337-350. DOI: 10.1016/j.chemgeo.2003.08.006

Laufer, F., Yariv, S. and Steinberg, M.:1984, The adsorption of quadrivalent Cerium by Kaolinite. Clay Miner., 19, 137-149. DOI: 10.1180/claymin.1984.019.2.02

Lobato, L.M., Viera, F.W.D.R., Rebeiro-Rodrigues, L.C., Pereira, L.M.M., Menezes, M.G.D., Junqueira, P.A. and Pereira, S.L.M.: 1998, Styles of hydrothermal alteration and gold mineralizations associated with the Nova Lima group of the Quadrilatero Ferrifero: part 1, description of selected gold deposits. Rev. Bras. Geocienc., 28, 339-354. DOI: $10.25249 / 0375-7536.1998339354$

Lowell, J.D. and Guilbert, J.M.: 1970, Lateral and vertical alteration-mineralization zoning in porphyry ore deposits. Econ. Geol., 65, 373-408.

Maksaev, V. and Zentilli, M.: 2002, Chilean strata-bound $\mathrm{Cu}-(\mathrm{Ag})$ deposits: An overview. In: Porter, T.M. (Ed), Hydrothermal Iron Oxide in Copper- Gold and related deposits. A Global Perspective, PGC Publishing, Adelaide, 163-184.

Maughan, D.T., Keith, J.D., Christiansen, E.H., Pulsipher, T., Hattori, K. and Evans, N.J.: 2002, Contributions from mafic alkaline magmas to the Bingham porphyry $\mathrm{Cu}-\mathrm{Au}-\mathrm{Mo}$ deposit, Utah, United States. Miner. Depos., 37, 14-37. DOI: 10.1007/s00126-001-0228-5 
Mohammadi, S., Nadimi, A. and Alaminia, Z.: 2018, Analysis of the relationship between mineralization and alteration zones with tectonic structures using remote sensing studies in south Ardestan area (northeastern Isfahan). Tectonics, 2, 7, 29-48. DOI: $10.22077 / \mathrm{JT} .2020 .2434 .1013$

Nabavi, M.H.: 1976, Introduction of geology of Iran. Geological Survey of Iran, 105.

Nabavi, M.H. and Houshmandzade, A.R.: 1979. Geological map of Khour. Geological Survey of Iran.

Niu, S.D., Guo, J., Xing, G.F., Huang, Z.Q., Wu, H.Y. and Fan, F.P.: 2020, Magmatism, geological setting, alteration, and metallogenic potential of Donghua area, Dehua County, Fujian Province, Southeast China: Insights from porphyry zircon $\mathrm{U}-\mathrm{Pb}$ and pyrite $\mathrm{Rb}-\mathrm{Sr}$ geochronology, geochemistry and remote sensing. Ore Geol. Rev., 126, 103726.

DOI: 10.1016/j.oregeorev.2020.103726

Oliveros, V., Féraud, G., Aguirre, L., Ramírez, L., Fornari, M., Palacios, C., and Parada, M.: 2008, Detailed 40Ar/39Ar dating of geologic events associated with the Mantos Blancos copper deposit, northern Chile. Miner. Depos., 43, 281-293. DOI: $10.1007 /$ s00126-007-0146-2

Patino, L.C., Velbel, M.A., Price, J.R. and Wade, J.A.: 2003, Trace element mobility during spheroidal weathering of basalts and andesites in Hawaii and Guatemala, Chem. Geol., 202, 343-364.

DOI: $10.1016 /$ j.chemgeo.2003.01.002

Pearce, J.A. and Norry, M. J.: 1979, Petrogenetic implications of $\mathrm{Ti}, \mathrm{Zr}, \mathrm{Y}$, and $\mathrm{Nb}$ variations in volcanic rocks. Contrib. Mineral. Petrol., 69, 33-47. DOI: $10.1007 / \mathrm{BF} 00375192$

Phillips, C.H., Harrison, E.D. and Smith, T.W.: 2005, Geology of the Bingham mining district: Salt Lake County, Utah. Super Porphyry copper and gold deposits: a global perspective, 1, 243-257.

Radfar, J. and Aminichehraq, M.R.: 2008, Geological map of Ardestan. Geological Survey of Iran.

Radfar, J., Kohansal, R., Zolfaqari, S. and Bahremand, M.: 2003, Geological map of Kouhpaye. Geological Survey of Iran.

Rajabi, S. and Torabi, Gh.: 2013, Petrology of Toveireh alkaline basalt an evidence of within-plate Oligocene volcanism in the northwest of Central-East Iranian Microcontinent, southwest of Jandaq. J. Petrol., 16, 21-38, (in Persian).

https://ijp.ui.ac.ir/article_16147.html.

Redmond, P.B. Einaudi, M.T., Inan, E.E., Landtwing, M.R. and Heinrich, C.A.: 2004, Copper deposition by fluid cooling in intrusion-centered systems-New insights from the Bingham porphyry ore deposit, Utah. J. Geol., 32, 217-220. DOI: 10.1130/G19986.1

Rollinson, H.: 1993, Using geochemical data: evalution, presentation, interpretation.

Rosemeyer, T.: 2011, News from the Keweenaw, Recent Mineral Finds in Michigan's Copper Country, part 4. Rocks and Minerals. 86, 206-227. DOI: $10.1080 / 00357529.2011 .568281$

Ruiz, C. and Peebles, F.: 1988, Geology, distribution and genesis of the Chilean metal deposits. University Publishing House, Santiago, Chile, 305.

Salvi, S. and Williams-Jones, A.E.: 1996, The role of hydrothermal processes in concentrating high-field strength elements in the Strange Lake peralkaline complex, northeastern Canada. Geochim. Cosmochim. Acta, 60, 11, 1917-1932.

DOI: 10.1016/0016-7037(96)00071-3

Shafiei, B. and Shahabpour, J.: 2000, Behavior, geochemical distribution, and mode of occurrence of gold and sdlver in the Sar cheshmeh Porphyry Copper Deposit, Kerman, Iran. Iran. J. Crystal. Miner., 33-56, (in Persian). http://ijcm.ir/article-1-859-en.html

Shahabpour, J.: 2000, Some Sulfide-Silicate Assemblages from the Sar Cheshmeh Porphyry Copper deposit, Kerman, Iran. J. Sci. I. R. Iran, 11, 1. https://jsciences.ut.ac.ir/article_31303.html.

Shahabpour, J.: 2001, Economic Geology. Publication of Shahid Bahonar university of Kerman, (in Persian).

Siddiqui, M.A. and Ahmed, Z.: 2008, Geochemistry of the Kaolin deposits of Swat (Pakistan). Chem. Erde, 68, 207-219. DOI: 10.1016/j.chemer.2005.11.001

Sillitoe, R.H.: 1992, Gold and copper Metallogeny of the central Andes: Past, present and future exploration objectives. Econ. Geol., 87, 2205-2216.

Sillitoe, R.H. and Perelló, J.: 2005, Andean copper province-Tectonomagmatic settings, deposit types, metallogeny, exploration, and discovery: Society of Economic Geologists. Econ. Geol., 100th Anniversary, 845-890.

Sillitoe, R.H.: 1973, The tops and bottoms of porphyry copper deposits. Econ. Geol., 68, 700-815. DOI: $10.2113 /$ gsecongeo.68.6.799

Sinclair, W.D.: 2007, Porphyry deposits, in Goodfellow. In: W.D., ed., Mineral deposits of Canada: A Synthesis of Major Deposit-Types, District Metallogeny, the Evolution of Geological Provinces, and Exploration Methods. Geological Association of Canada, Mineral Deposits Division, Special Publication, 5, 223-243.

Skewes, M.A. and Stern, C.R.: 2007, Geology, mineralization, alteration, and structural evolution of the El Teniente porphyry $\mathrm{Cu}-\mathrm{Mo}$ deposit-A discussion. Econ. Geol., 102, 1165-1180.

DOI: 10.2113/gsecongeo.102.6.1165

Skewes, M.A., Arévalo, A., Floody, R., Zuñiga, P., Stern, C.R. and Porter, T.M.: 2005, The El Teniente megabreccia deposit, the world's largest copper deposit. Super porphyry copper and gold deposits-a global perspective. Adelaide, Australia, Porter Geoscience Consultancy Publishing, 1, 83-113. https://www.semanticscholar.org/paper/THE-ELTENIENTE-MEGABRECCIA-DEPOSIT.

Stern, C.R. and Skewes, M.A.: 2005, Origin of giant Miocene and Pliocene $\mathrm{Cu}-\mathrm{Mo}$ deposits in Central Chile-Role of ridge subduction, decreased subduction angle, subduction erosion, crustal thickening and longlived, batholith-sized, open-system magma chambers. In: Porter, T.M., ed., Superporphyry copper and gold deposits-A global perspective, Adelaide, Porter Geoconsultancy Publishing, 1) 65-82.

Sun, S.S. and McDonough, W.F.: 1989, Chemical and isotopic systematics of oceanic basalts, implications for mantle composition and processes, In: Saunders, A.D. and Norry, M.J., eds., Magmatism in the ocean basin. Geological Society of London Special Publication, 42, 313-345.

Swenson, J.B. and Person, M.: 2000, The role of basin-scale transgression and sediment compaction in stratiform copper mineralization: implications from White Pine, Michigan, USA. J. Geochem. Explor., 69-70, 239243. DOI: $10.1016 / \mathrm{S} 0375-6742(00) 00052-2$ 
Tassongwa, B., Eba, F., Njoya, D., Tchakounté, J.N., Jeudong, N., Nkoumbou, C. and Njopwouo, D.: 2017, Physico-chemistry and geochemistry of Balengou clay deposit (West Cameroon) with inference to an argillic hydrothermal alteration. C. R. Geosci., 5, 212-222. DOI: $10.1016 /$ j.crte.2017.06.002

Taylor, S.R. and McLennan, S.M.:1985, The continental crust: Its composition and evolution. Blackwell, Oxford, 312. DOI: 10.1002/gj.3350210116

Tristá-Aguilera, D., Barra, F., Ruiz, J., Morata, D., TalaveraMendoza, O., Kojima, S. and Ferraris, F.: 2006, ReOs isotope systematics for the Lince-Estefanía deposit: constraints on the timing and source of copper mineralization in a stratabound copper deposit, Coastal Cordillera of Northern Chile. Miner. Depos., 41, 99-105. DOI: 10.1007/s00126-006-0048-8

Ullah, Z., Li, J.W., Robinson, P.T., Wu, W.W., Khan, A., Dac, N.X. and Adam, M.M.A.: 2020a, Mineralogy and geochemistry of peridotites and chromitites in the Jijal Complex ophiolite along the Main Mantle Thrust (MMT or Indus Suture Zone) North Pakistan. Lithos, 366, 105566. DOI: 10.1016/j.lithos.2020.105566

Ullah, Z., Shah, M.T., Siddiqui, R.H., Lian, D.Y. and Khan, A.: 2020b, Petrochemistry of high-Cr and high-Al chromitites occurrences of Dargai complex along indus suture zone, northern Pakistan. Episodes, 43, 2 , 689-709. DOI: 10.18814/epiiugs/2020/020002

Walker, T.R., Waugh, B. and Crone, A.: 1978, Diagenesis in first-cycle desert alluvium of Cenozoic age, southwestern United States and northeastern Mexico. Geol. Soc. Am. Bull., 89, 19-32.

DOI: $10.1130 / 0016-7606(1978) 89<19$

Whitney, D.L. and Evans, B.W.: 2010, Abbreviations for names of rock-forming minerals. Am. Miner., 95, 185187. DOI: $10.2138 / \mathrm{am} .2010 .3371$

Wilson, N.S.F. and Zentilli, M.: 2006, Association of pyrobitumen with copper mineralization from the Uchumi and Talcuna districts, Central Chile. Int. J. Coal Geol., 65, 158-169. DOI: $10.1016 /$ j.coal.2005.04.012

Winchester, J.A. and Floyd, P.A.:1977, Geochemical discrimination of different magma series and their differentiation products using immobile elements. Chem. Geol., 20, 325-343. DOI: 10.1016/0009-2541(77)90057-2

Xiao, B., Chen, H., Hollings, P., Wang, Y., Yang, J. and Wang, F.: 2018, Element transport and enrichment during propylitic alteration in Paleozoic porphyry $\mathrm{Cu}$ mineralization systems: insights from chlorite chemistry. Ore Geol. Rev., 102, 437-448.

DOI: 10.1016/j.oregeorev.2018.09.020

Zhou, Y. and Wang, Z.: 1999, Altered ductile shear zone host type of gold deposits from South China. A case study. J. Geosci. China, 1, 23-38.

Zhou, Y., Li, L., Yang, K., Xing, G., Xiao, W., Zhang, H., Xiu, L., Yao, Z. and Xie, Z.: 2020, Hydrothermal alteration characteristics of the Chating $\mathrm{Cu}-\mathrm{Au}$ deposit in Xuancheng City, Anhui Province, China. Significance of sericite alteration for $\mathrm{Cu}-\mathrm{Au}$ exploration. Ore Geol. Rev., 127, 103844.

DOI: 10.1016/j.oregeorev.2020.103844 